Portland State University

PDXScholar

3-4-1993

\title{
The Study of Malaysian Learners' Strategies while Studying a Second Language
}

Phoebe Christina Leong

Portland State University

Follow this and additional works at: https://pdxscholar.library.pdx.edu/open_access_etds

Part of the Bilingual, Multilingual, and Multicultural Education Commons, and the Language and Literacy Education Commons

Let us know how access to this document benefits you.

\section{Recommended Citation}

Leong, Phoebe Christina, "The Study of Malaysian Learners' Strategies while Studying a Second Language" (1993). Dissertations and Theses. Paper 4597.

https://doi.org/10.15760/etd.6481

This Thesis is brought to you for free and open access. It has been accepted for inclusion in Dissertations and Theses by an authorized administrator of PDXScholar. Please contact us if we can make this document more accessible: pdxscholar@pdx.edu. 
AN ABSTRACT OF THE THESIS OF Phoebe Christina Leong for the Master of Arts in TESOL presented March 4th, 1993.

Title: The Study of Malaysian Learners' Strategies while Studying a Second Language

APPROVED BY MEMBERS OF THE THESIS COMMITTEE:
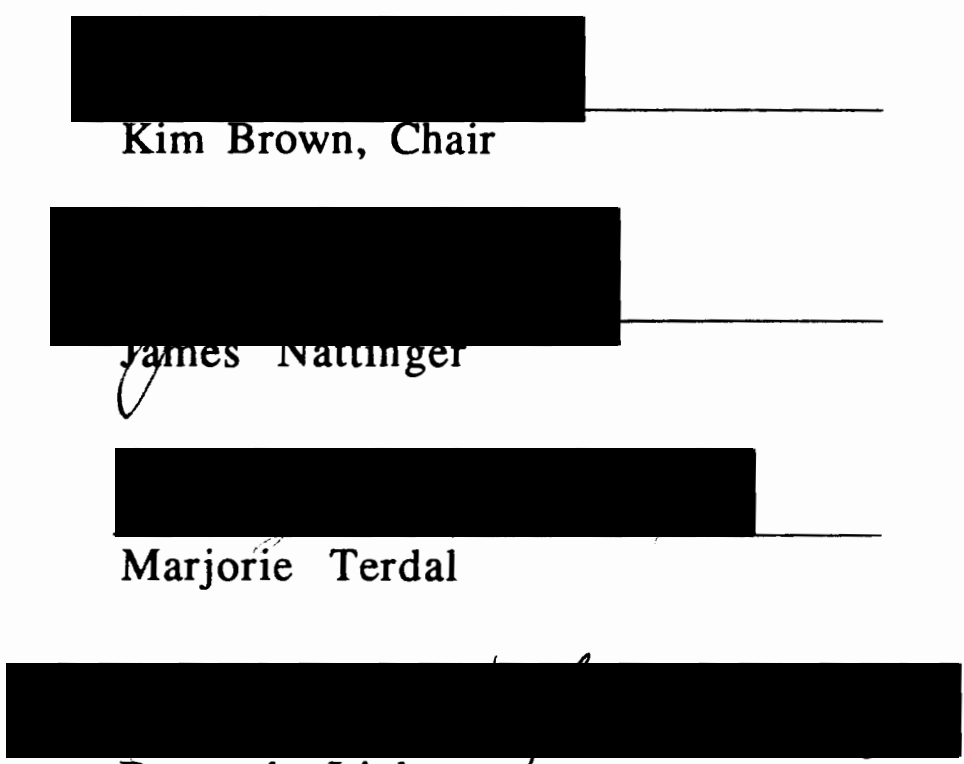

Devorah Lieberman

In the past, the process by which language acquisition took place was largely ignored. Learning strategies were found to reveal much of the processes that occured in a learner. In recent years, however, there was a greater emphasis in discovering learner's 
strategies because of the important role it played in helping the learner control his learning.

Most researchers (e.g., Rubin 1975, Stern 1974, O'Malley 1985) emphasize not only the importance of learner strategies in helping the student direct his own learning, but they also emphasize the usefulness of transfering strategies used by successful learners to less successful learners.

In order to discover the number and type of strategies that Malaysian learners actually use, it was necessary to distinguish first the successful and unsuccessful learners as well as to distinguish the three different ethnic groups (Malays, Chinese, and Indians) that live in Malaysia. This study examines an aspect of learner strategies in a multi-cultural environment, and attempts to answer research questions regarding the following:

1. The kind of strategies used by successful and unsuccessful learners within each ethnic group.

2. The number of strategies used by successful and unsuccessful learners within each ethnic group.

3. The kind of strategies used by successful learners among the three groups.

4. The number of strategies used by successful and unsuccessful learners among the three groups. 
To examine these questions, Oxford's Strategy Inventory for Language Learning (SILL) was employed on ninety-eight Malaysian subjects. The inventory consisted of 50 questions consisting of six major strategy groups (memory, cognitive, compensation, metacognitive, affective, and social). The data from the questionnaires was statistically analyzed using the Kruskal-Wallis and the Mann-Whitney $U$ test.

It was discovered that successful and unsuccessful Malaysian learners in general did not use strategies very differently from each other. The only strategy that seemed to be used differently was memory and affective strategies. The number of strategies used did not also differ very significantly from each other. Their close mean scores indicated that the difference in the number of strategies used was minimal. Also, the most frequently used strategies appeared to be metacognitive and compensation strategies for all three ethnic groups.

It would seem surprising that given the multi-cultural environment, and the differences in the Malaysian learners background, the type and number of strategies did not appear to differ very much from each other. The reason could lie in Oxford's inventory which seemed to be more Western-based than Easternbased, or it could be that something else was happening here, and Malaysian learners were using a whole different set of strategies not listed in Oxford's SILL. Nevertheless, the differences in findings among different countries may reveal to us that findings in one 
country are greatly linked to their cultural backgrounds, and thus one should be cautious in trying to generalize it for other countries. 
THE STUDY OF MALAYSIAN LEARNERS' STRATEGIES WHILE STUDYING A SECOND LANGUAGE

b y

PHOEBE CHRISTINA LEONG

A thesis submitted in partial fulfillment of the requirements for the degree of

MASTER OF ARTS

in

TESOL

Portland State University

1993 
TO THE OFFICE OF GRADUATE STUDIES:

The members of the Committee approve the thesis of Phoebe Christina Leong presented March 4th, 1993.

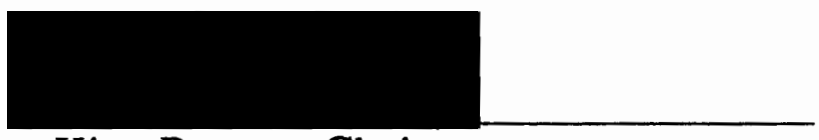

Kim Brown, Chair
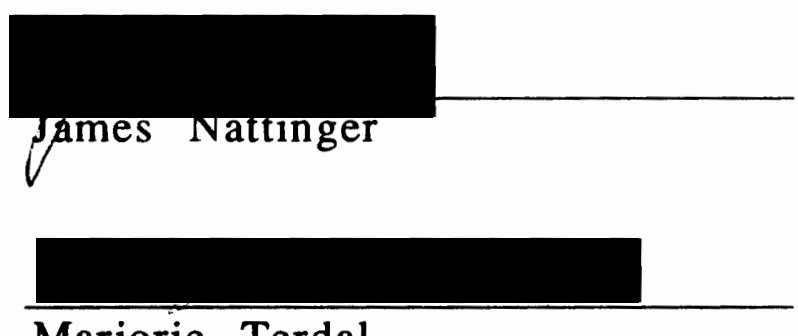

Marjorie Terdal

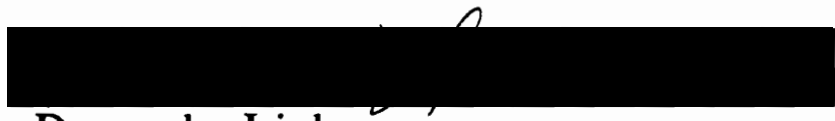

Devorah Lieberman

APPROVED:

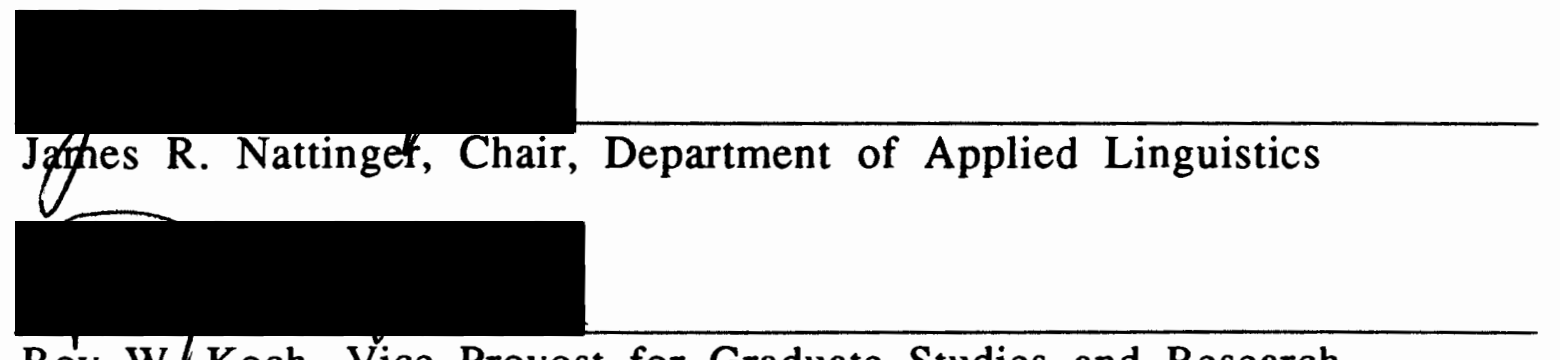

Roy W. Koch, Vice Provost for Graduate Studies and Research 


\section{ACKNOWLEDGEMENTS}

I wish to express my special thanks to Dr Kimberley Brown, my thesis advisor, who has guided and supported me throughout the whole process. I thank Dr Brown for her time, patience and advice.

My thanks also extend to my friends, David Dewert and Maureen Early for their help, support and concern.

But, most of all, I cannot thank enough my only guiding force, constant advisor and greatest supporter in everything I do, my father. 
TABLE OF CONTENTS

PAGE

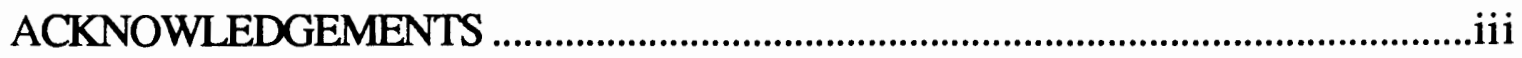

LIST OF TABLES ................................................................................................ vii

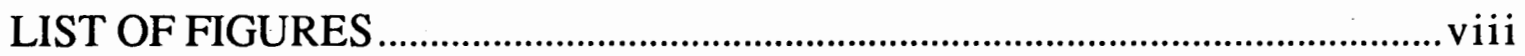

\section{CHAPTER}

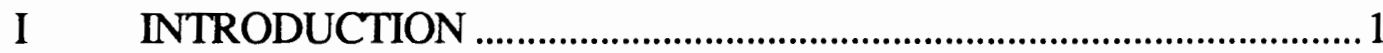

Statement of the Problem...................................................2

Purpose of this Study ...............................................................

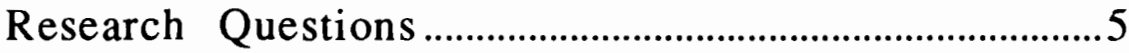

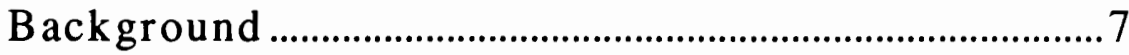

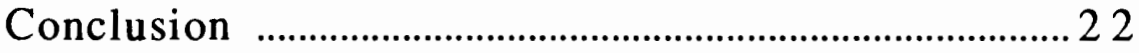

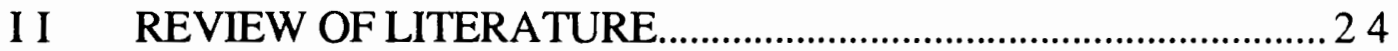

Introduction and Overview

of Learning Strategies ............................................2 24

Theoretical Models of Second

Language Learning .................................................. 30

Empirical Studies in Language

Learning Strategies................................................ 34

Comparisons of Inventories............................................ 39 


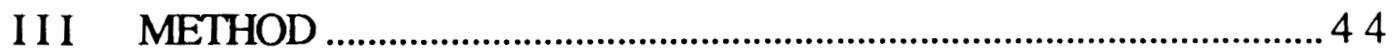

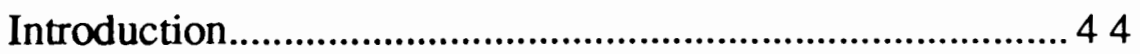

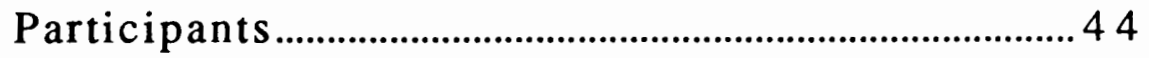

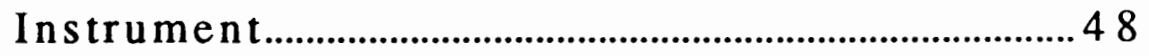

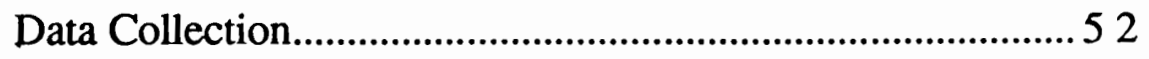

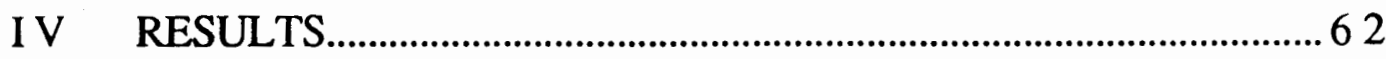

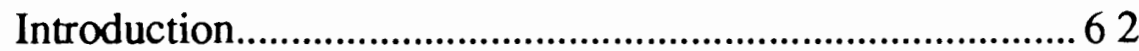

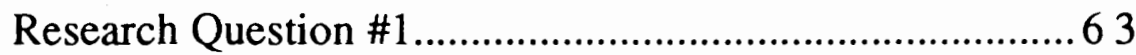

Research Question \#2........................................................ 70

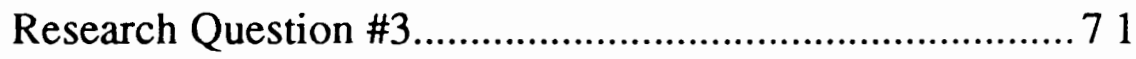

Research Question \#4................................................... 72

Research Question \#5..................................................... 74

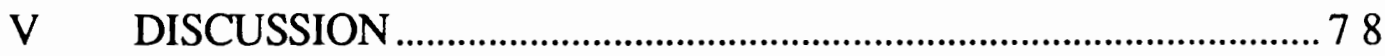

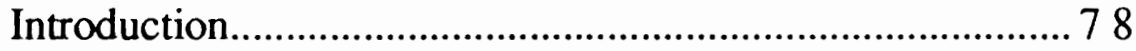

Research Questions ........................................................... 79

Limitations of the Study ............................................... 98

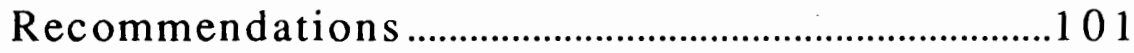

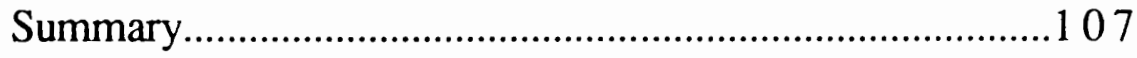

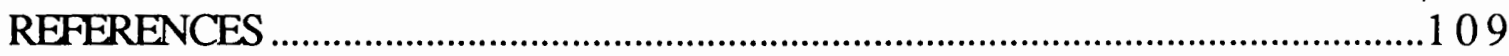

APPENDICES

A BACKGROUND QUESTIONNAIRE....................................114

B TRANSLATED BACKGROUND 


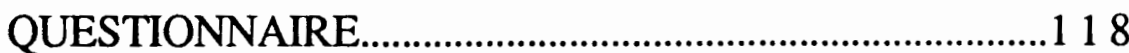

C STRATEGY INVENTORY FOR

LANGUAGE LEARNING ...................................................1 122

D TRANSLATED SILL VERSION .........................................134

E UNTRANSLATABLE WORDS ...........................................147

F STATEMENTS/STRATEGIES USED

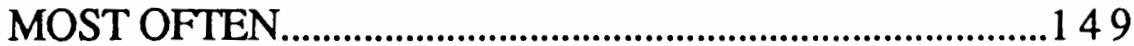




\section{LIST OF TABLES}

TABLE

PAGE

I Overview of Malaysian Subjects ........................................................46

II Comparison of Oxford's Strategies and Stern's

Strategies

III Mann Whitney U Test: Comparison of Strategies

between the Successful and Unsuccessful

Malay Learners 64

IV Mann Whitney U Test: Comparison of Strategies

between the Successful and Unsuccessful

Chinese Learners

V Mann Whitney U Test: Comparison of Strategies

between the Successful and Unsuccessful

Indian Learners

VI Kruskal-Wallis Comparison of Strategies by Ethnic

Groups of Successful Learners.

VII Kruskal-Wallis Comparison of Strategies by Ethnic

Groups of Successful Learners.

VII Statistically Significant Values of All Ethnic Groups .77 


\section{LIST OF FIGURES}

FIGURE

PAGE

1. Bialystok's (1978) Model of Second Language

Learning

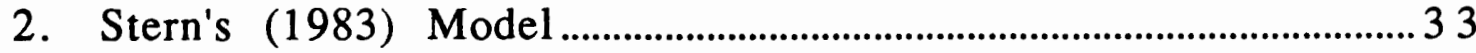

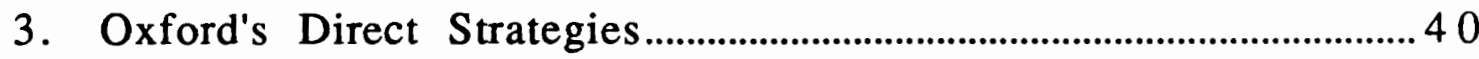

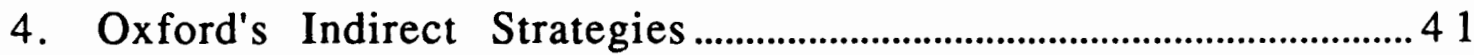

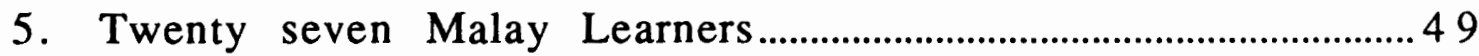

6. Forty seven Chinese Learners.........................................................5

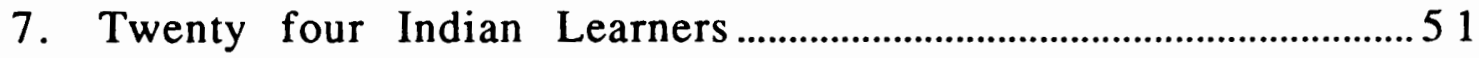

8. Oxford's (1990) Strategies as Used by Malaysian

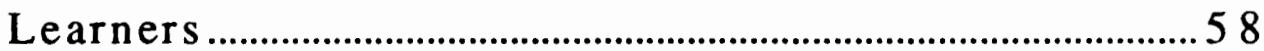




\section{CHAPTER I}

\section{INTRODUCTION}

This study examines an aspect of language learning strategies in a multi-cultural environment. Specifically, it takes a close look at the strategies that are used by Malaysian language learners and compares the strategies that are used by successful and unsuccessful learners. The study will be useful since little research on learning strategies has been done in the East or South East Asian region, and also this will be the first of its kind in Malaysia. If it is discovered that successful Malaysian learners use different strategies, then the identification and study of their strategies could ultimately be used to help improve unsuccessful Malaysian learners' acquisition of a second language.

An overview of Malaysia in terms of its history, cultural, sociolinguistic and political backgrounds is given. Under the British rule, English was considered important as a status symbol as well as a means for a better livelihood. For these reasons, people's attitude towards the language was positive. However, after Malaysia gained its independence, the National Language Act of 1967 was put into effect. The Act changed the official and national language from English to Bahasa Malaysia and subsequently influenced the attitude of the people towards English and caused a decline in the general 
level of English proficiency. There presently is a lack of interest among most rural Malaysians in learning English, for they do not see themselves using it in the future, while the attitude is better among most urban-educated ethnic groups. The government, however, is aware of the general decline of English in most schools and its potentially negative effects on future generations. The attitude change of the people and certain other governmental policies may have influenced the manner in which learners study English.

The purpose of this study is to explore the kinds of strategies (cognitive, metacognitive, compensation, memory, social, and affective) successful and unsuccessful Malaysian secondary students employ while learning English.

\section{STATEMENT OF THE PROBLEM}

In the past, much language research has focused on student production, while less research has examined student processes. Overall learner language proficiency used to be measured by what was actually said or written, but the process by which language acquisition took place (eg., learning strategies) was largely ignored. However, since the 1970's, research has focused more on discovering learner processes, i.e., how learners derive their answers, and less on learner product, i.e., the correct answers. As Oxford (1990) explains, 
Interest has been shifting from a limited focus on merely what students learn or acquire -- the product or outcome of language learning and acquisition -- to an expanded focus that also includes how students gain language -. the process by which learning or acquisition occurs (p. 5).

More importantly, an increasing number of researchers in the field of second language learning and teaching feel that it would be beneficial from a theoretical as well as from a practical point of view to learn more about these successful or 'good' language learners. If indeed, there are certain strategies that are used by more successful students, the identification of such common features would prove to be useful to the field (Naiman, Froehlich and Todesco, 1975; Rubin, 1975; Stern, 1974).

\section{PURPOSE OF THIS STUDY}

The purpose of this study is to examine student language learning strategy use in two classes in West Malaysia. More specifically, I am interested in examining the number and types of strategies used by successful and unsuccessful Malaysian students in these schools. Successful learners are the ones who are able to devise their own strategies that maximize their full potential when acquiring a second language. Past research (Naiman et. al., 1975, O' Malley et. al. 1985a) indicates that the strategies of successful learners can be isolated, examined and taught to less successful learners. If teachers teach strategies that are useful to learners, they 
will be able to make classroom learning easier, more efficient, and self-directed (Wenden, 1985; Rubin, 1975; Oxford \& Nyikos, 1989).

This study will look at the extent to which Malaysian learners use or do not use strategies (i.e., number of strategies), and the types of strategies used (i.e., different kinds of strategies) by successful and unsuccessful Malaysian language learners. Most studies have demonstrated that successful learners not only generally use a wider range and more strategies than unsuccessful learners, but also employ different strategies (Chamot \& Kupper, 1989). For most of the above-named researchers, applications of their work include developing ways for unsuccessful language learners to increase their overall level of proficiency by emulating the strategies of successful language learners. Although recent studies have been carried out on identifying, developing, and where feasible, refining these strategies in many language learning situations in order to make them more efficient, not much of such studies had been previously investigated on strategies of Malaysian learners. A great deal of learning strategy research was carried out primarily in the West, but often confirmation of prevalent hypotheses was not tested cross-culturally in non-European international settings.

Secondly, the study will attempt to find out if the kinds of strategies that successful learners employ fit those proposed by Stern (1974). In order to do this, the study takes a close look at the strategies that are used most often by successful learners and compares them to the lists suggested by Stern that encompass good learning strategies of successful learners. 
I have decided to focus my study on Malaysians for several reasons. First of all, I am a Malaysian myself and therefore there is a certain curiosity and intrigue for me to find out similarities and differences in strategies among the three major ethnic groups (Chinese, Malays,. and Indians) in West Malaysia. Second, I believe that this will be the first study done focusing on learning strategies in West Malaysia. Hence, my study will be very beneficial for other researchers who may be interested in exploring or expanding their work in this particular region. Third, I believe that being a Malaysian gives me the advantage of collecting data and information that would otherwise be more difficult for non-Malaysians to access.

\section{RESEARCH QUESTIONS}

This study identifies the strategies produced by Malaysian learners in a multi-ethnic environment and compares the results between successful and unsuccessful learners. More specifically, this study is intended to answer five major research questions:

1) Within the Malay, Chinese, and Indian ethnic groups, do successful English language learners employ the same kind of learner strategies as unsuccessful learners?

2) Within the Malay, Chinese, and Indian ethnic groups, do successful English language learners have significantly 
different mean scores on the Strategy Inventory for Language Learning (SILL) than unsuccessful learners?

3 Within successful learner groups, do the Malay, Chinese, and Indian ethnic groups have significantly different mean scores on the Strategy Inventory for Language Learning (SILL)?

4) Within unsuccessful learner groups, do the Malay, Chinese, and Indian ethnic groups have significantly different mean scores on the Strategy Inventory for Language Learning (SILL)?

5) Do the successful learners employ most of the strategies proposed by Stern?

To answer the first question, this study reports quantitative analyses of the strategies used by both types of learners. To answer the second question, the questionnaire responses of successful and unsuccessful students of each ethnic group will be compared to each other. To answer the third question, the questionnaire responses of successful Malay, Chinese and Indian learners will be compared to each other. Similarly, to answer the fourth question, the questionnaire responses of unsuccessful Malay, Chinese and Indian learners will be compared to each other. In order to answer question 5 , this study will look at the most frequently used learner strategies and make a comparison with those proposed by Stern. The 
background of Malaysian people, Malaysia's geography, politics, and economic factors are discussed in order to explain differences among the three major ethnic groups.

\section{BACKGROUND}

Learning strategies are defined as behaviors, techniques or actions used by students, often consciously, to enhance their learning (Oxford, 1990). Chamot and Kupper (1989) define them as, "techniques which students use to comprehend, store, and remember new information and skills" (p. 13). Learning strategies include such activities as reviewing English lessons often, talking like native speakers, trying to find patterns in English, making guesses, and looking for opportunities to read as much as possible in the foreign language. In other words, strategies are anything that learners use cognitively, metacognitively, affectively, and socially to help them improve their proficiency. Oxford (1990), for example, has tracked down almost all known strategies, but she also admits that there is no complete agreement on how many exist or what exactly strategies are (p. 19). Oxford's strategy inventory provides a comprehensive list of strategies covering several strategy components, such as, memory strategies (A), cognitive strategies (B), compensation strategies (C), metacognitive strategies (D), affective strategies (E) and social strategies (F). This study draws upon Oxford's (1990) Strategy Inventory of Language Learning (SILL). 
Little research on learning strategies has been done in the East or South East Asian regions. Huang (1984) has investigated learning strategies in oral communication that Chinese English as a Foreign Language (EFL) learners employ. However, further research on learning strategies of Chinese students has not been reported in any major language learning journals. In West Malaysia, numerous studies have been written about Malaysian English but no studies exploring Malaysian language learner strategies have been reported.

There are general aspects of the language situation in West Malaysia that are inextricably linked to the language acquisition process. Tollefson (1981) provides a language planning process consisting of a set of variables that he believes in turn affect input, learner, learning, and learned variables. The set of variables includes language situation variables, macro-policy goals, macroimplementation decisions, micro-policy goals and microimplementation decisions. These variables consist of numerous decisions and planning levels which eventually affect second language acquisition.

According to Tollefson (1981), language situation would refer to who (ages, socioeconomic classes, ethnic and regional groups, etc.) speaks (with what level of proficiency) what language varieties (social and regional dialects, registers, autonomous languages) to whom (ages, socioeconomic classes, ethnic and regional groups, etc), and for what purposes (business and trade, religion, education, government activity). 
As for macro-policy goals, they are formulated by federal authorities to influence local authorities in implementing the policy plans. Macro-policy goals consist of language maintenance or language shift, structural changes in a variety or changes in the functional distribution.

Macro-implementation decisions include at the national level programs such as teacher training, publication of textbooks, establishment of curriculum standards and requirements, and scholarships and exchange programs. In West Malaysia, the macro policy goal that the government had was to shift the language from English to Bahasa Malaysia.

Micro-policy goals and implementations are more involved on the local level. Micro-policy goals are language planning goals set mainly by language educators and administrators at the local level, for example, in a school setting. Implementation of micro-policy goals occurs with specific actions such as designing a curriculum or maintaining/changing a teaching methodology in the classroom.

When macro and micro policy goals are implemented at both the national and local level, the shift in language in the social settings of West Malaysia and the classroom ultimately affects the attitude and motivation (learner variables) of the people. The effect attitude and motivation has on the people may then in turn shape the use of certain strategies. For example, it is generally known that the attitude of urban Malays toward English is more positive than rural Malays for various reasons. The ethnic mix at an urban school, for 
example, demands more participation in the use of social strategies than it would in a rural school, where there is more homogeneity.

In the following discussion, I will present examples and situations of the language situation and policy goals in West Malaysia in terms of Tollefson's (1981) language planning in second language acquisition.

\section{Language Situation}

In order to understand the language and culture of West Malaysia, it is necessary to have some background knowledge of what the language situation and sociolinguistic climate were like before West Malaysia achieved its independence from the British in 1957. This information is relevant because under British rule, English was the official language of the country, and had a tremendous amount of influence in shaping peoples' attitude towards the language. The background knowledge of West Malaysia is important in understanding how English was perceived and also employed at home and in school, as opposed to today's perception, attitude change and the employment of the language at home and in school.

To be able to speak fluent English was considered prestigious.. It meant that the individual was at the level of the British. As such, the attitude of Malaysians towards English during the British rule was positive. This is important because it is my contention as well as others, that people's attitudes influence the learning strategies that they use. Numerous researchers (Raymond, 1970; Gardner \& 
Lambert, 1972; Lukmani, 1972; Oxford \& Nyikos, 1989) have explored the links between attitude, motivation and language learning. Gardner and Lambert (1972), for example, stipulated two types of motivational factors: integrative and instrumental. Integrative motivation was related to learner willingness to be part of a target language, to become like its members, while instrumental motivation was related to learner desire to use the language for practical utilitarian reasons. They discovered that integrative motivation was more characteristic of successful second language learners than was instrumental motivation. But Lukmani (1972) found that for Indian learners, instrumental motivation was more closely linked to success than integrative motivation. Gardner and Lambert (1972) also found that the type of motivation (instrumental/integrative) would vary according to the cultural setting. Oxford and Nyikos (1989) found that degree of motivation influences learners to use a variety of strategies.

Besides English, other languages such as Chinese, Bahasa Malaysia (hereafter B.M.) or Indian languages are also spoken in West Malaysia. This reflects the great diversity of the population. However, in the past, the colonial language was the dominant language, in the sense that it was the primary language used in employment. Hence, in order to obtain a good job or get promoted, one was required to have good knowledge of English. In this sense, everyone viewed English as an important language, and an asset to have if one desired a better future. 
West Malaysia's population is multi-ethnic, consisting of Malays, who constitute 53.5 percent of the population, Chinese at 35.3 percent, Indians about 10.5 percent, and others at 0.7 percent. (Joefer, 1985). As can be seen, the majority of the population are Malays, also known as "Bumiputras" (sons of the soil), and the rest constitute minorities. The total population of West Malaysia presently is approximately 18 million.

The distribution of population in West Malaysia is rather spread out and this spread influenced the languages used in certain areas. The wide geographical spread of English in West Malaysia also influenced the English proficiency level of Malaysians. When the language was concentrated in a small geographical area and was the medium of instruction in selected schools (mainly in urban areas), the level of proficiency was very high. But now that English has spread over a wider region and become a compulsory second language for everyone, the level of proficiency is lower. This is one of the language situations in West Malaysia today where the spread of English is a lot wider, and where English has been made a compulsory second language. The level of proficiency in urban and rural areas has slowly declined over time.

The concentration of English in certain areas during the British rule had a major impact on the job opportunities available for certain ethnic groups. This was due to certain ethnic groups concentrating in one particular area. In terms of geographical distribution of the population, about $30 \%$ of the total population (about 5 million) is found in urban areas. The Chinese form the largest majority of the 
urban population, while the Malays form the largest majority in the rural areas (Omar, 1984). Prior to 1957, a large portion of government education subsidies was distributed to English medium schools mainly located in urban areas, thereby enabling the Chinese, more than Malays or Indians, to have better teachers and facilities. Also, students from English schools had a greater advantage of entering universities in West Malaysia, Singapore and the British Commonwealth. Furthermore, individuals who graduated from these countries had greater opportunities as compared to those who graduated elsewhere. Therefore, there was a great deal of imbalance in terms of opportunities for the various ethnic groups. This was one of the main reasons for the government to introduce the 1967 National Education Act. This policy was considered essential if the country was to have a national identity, unity and equality.

Due to the concentration of English in urban areas, the urban educated of all ethnic groups prefer English, while Chinese and Tamil dialects are spoken in Chinese and Indian homes in general (Aznam, 1988). The urban educated Malays were more interested in learning English because of the encouragement given to them by their parents who were proficient in the language and sometimes conversed in English at home. Second, urban educated Malays were also more likely to come into contact with the other two ethnic groups, who were more likely to speak English with them, since their peers may be of a different background and may not speak B.M. very well.

For many rural Malays, on the other hand, English appeared to be something of a necessary evil. This was because most Malaysians 
of all ethnic groups would acknowledge that rural Malays appeared to be clannish and that they considered English an unwelcome foreign influence that clashed with their religion and lifestyle. The British tried to convert Malaysians to the Christian religion, besides implementing English as the primary language. Rural Malays, especially highly resented the British attempts to influence and convert them. This was an impact felt by most Malays during the British occupation in West Malaysia.

There are basically three types of Chinese. The first type are the urban educated Chinese who speak English rather well at home and in school, and have developed positive attitudes toward the language. The second type are also urban educated but do not speak English very well mainly because English was not spoken at home. Even though their attitude towards the language was not very positive, they nevertheless envied the more proficient English speakers. The third type are the rural Chinese who hardly speak any English at home or in school. Most of them enroll in private Chinese schools where the medium of instruction is Chinese. Their attitude towards English is not very positive either.

We have looked at the Malaysian language situation so far in terms of Tollefson's (1981) definition of who (ethnic groups), speaks (with what level of proficiency) what language varieties (social and regional dialects) to whom (ethnic groups), and for what purposes (business, education). Now we will look further into how Malaysians' perception, attitude, language proficiency and ultimately language strategies were influenced with the advent of certain macro and 
micro policy goals that were put into effect after the British moved out.

\section{Macro-policy goals}

Soon after West Malaysia gained its independence in 1957, and the National Language Act (1967) was put into effect, the emphasis on English shifted. The National Language Act (1967) changed the medium of instruction from English to B.M., and made B.M. the official and national language of the country. This language change, which was deemed a political and social move, greatly influenced the attitude of the people, and caused a slow decline in English usage, and in the ways Malaysians learn English. People began to concentrate on B.M. rather than English and this language shift signaled a shift in their attitude towards both languages. They began to view B.M. in a more positive way and English in a negative way (Omar, 1984).

The implementation of this policy essentially sent a message to Malaysians that B.M. was more important than English, since B.M. was then used in virtually all major government offices, businesses and schools. Consequently, English no longer remained the dominant language, nor was it considered absolutely necessary to know in order to obtain a good job or to hold a powerful economic or political position (Omar, 1984). 
Macro-implementation decisions

After the National Language Act (1967) was implemented, the government committed funds for teacher training programs, publication of textbooks and the establishment of curriculum standards at the national level.

In the beginning, the government introduced teacher training programs in B.M. for the local teachers. But in time, when the government realized for political and economic reasons, which will be discussed later in this chapter, the growing importance of English, the need for English teachers increased. The government began to introduce teacher training programs in West Malaysia and also send others abroad for training. The continued lack of English teachers, however, prompted the government to import foreign language teachers from the United States, Great Britain, Canada and Australia.

However, the government was met with numerous protests in the hiring of foreign teachers since it was paying exorbitant salaries to the foreign teachers as compared to Malaysia's overseas-trained local teacher. As a result, this form of hire was quickly abolished. Today, very few foreign teachers are hired. Furthermore, the government is fearful of the rising Muslim Fundamentalists who consider the re-emphasis of English as a threat to B.M.

The English language has now been changed into a political issue, whereby the government dares not try anything "radical" that may help reform the system. There has been a vast discussion on the English issue, but very little action has been taken. In addition, Malaysians are also questioning the relevance of English in Malaysian 
society today. They wonder if it is at all necessary for everyone. According to Omar (1984), one-third of the educated population need English, two-thirds of the total population need it only for trade, and the rest of the educated and uneducated population not at all.

The Malaysian government has also attempted to translate many of the textbooks from English to B.M.. However, West Malaysia has not been able to keep up with the translation of many textbooks due to the enormous volume of books published each year. In fact, the amount of advanced materials available in B.M. has remained extremely limited. According to Cohen (1988), producing advanced material in B.M. has not been easy. There are only 300 translators who work on textbooks, and they are unable to meet the demand. In 1987, for example, only 43 college texts were translated. Hence, the number of translated works in B.M. continue to remain few, and neither the government nor the university presses are able to recover the cost for producing such works. Furthermore, many Malaysian scholars still prefer to publish in English in order to reach a worldwide audience. As such, Malaysians are still required to read numerous materials in English at the universities.

\section{Micro-policy goals}

The National Policy Act (1967) was introduced mainly to equal out the imbalances of job opportunities created by language, and also to unite the people as one.

On a local and individual level, the government tried to decide how to implement this act, which basically promoted the increased 
need for B.M. and less need for English. For example, a newspaper such as the New Straits Time had to decide in their style sheet which B.M. terms could be used in this English newspaper.

According to Tollefson (1981), in the classroom the individual goals could be accomplished if specific actions were to be taken by school administrators or language educators. Some specific actions that could be taken included methodology used in classrooms and testing, which will be further discussed in the next section.

\section{Micro-implementation decisions}

Today, in most Malaysian classrooms, English lessons are usually given in a forty-five minute period each day. The methodology most frequently used in these classes is grammarbased in keeping with the traditional Eastern way. Unlike typical Western ways which are more communicative, Malaysian classroom activities are much more based on rote memorization, drills, ruleorientation, and textbook-orientation. The classes are very teachercentered. Conformity rather than creativity is encouraged, and in general, learners are not encouraged to think of learning in new ways. Such a structured form of learning may have an influence on students' use of conscious strategies.

Testing is another example of a micro-implementation decision that has a profound impact on the language situation in West Malaysia. When English was relegated to the status of second language as opposed to being the only official language, the government lowered the standard of English tests. All other subject 
tests were to be taken in B.M. With the lowering in the standard of English tests, the government irrevocably influenced the attitude of Malaysians toward English. The Malaysians realized they did not have to work so hard on English anymore, and the lowering inthe standard of English tests made them think that it was not as important as Bahasa Malaysia. Only recently, in an attempt to promote better fluency in English, has the government introduced oral examinations at a national level. This is an attempt by the government to emphasize the importance of English today.

\section{Learner variables}

All the above mentioned variables, such as the macro-policy goals, implementation decisions, micro-policy goals and implementation decisions have an effect on other variables such as learner variables. It is my belief that these variables were put into effect by the government to standardize B.M., to influence language use and to promote nationalism in West Malaysia. In achieving these goals, the National Language Act (1967) came into effect. One of the variables affected by this implementation was learner variables, which include students' attitude and motivation.

There exists some differences in attitude among the different ethnic groups themselves. For example, the Chinese and Indians may look more favorably on English than the Malays. There are several possible reasons for their differences in attitude. It is common knowledge in West Malaysia that Chinese look more favorably on English since they hold the economic power in West Malaysia and 
must do business internationally and locally using English. Like the residents of Hong Kong and India, Malaysian Chinese benefited economically from English colonization. Second, due to Malaysia's history, the older Chinese and Indian people who benefited from previous English-medium-instructions may give more encouragement to their children to excel in English and may also speak more English at home. Third, B.M. is not the Indians' or Chinese native tongue and as such they tend not to do well in the B.M. language examinations, which happens to be a criterion for admittance into Malaysian universities. As a consequence, many are required to go overseas (e.g., Australia, Great Britain or the United States) for further education, and as such there may be a greater emphasis on learning English for the minorities.

At present, most Malaysians show a general lack of motivation/interest in learning English if they do not see themselves using it in the future. If they conduct business within the country, they do not see the need to use English since B.M. is more than sufficient. However, in multi-national corporations where business has to be conducted internationally, English is important. For these kinds of businesses, English proficiency is then made part of the job descriptions. Due to the government's implementation of a quota system that favors Bumiputras, seventy percent of Malays enter universities. Upon graduation, most or all of them then proceed to work in West Malaysia using B.M. in the workplace. The minorities have less chance of entering the universities each year, and hence they go overseas for study (Cohen, 1988). Meanwhile, the Malaysian 
government recognizes the general decline of English and its potentially negative effects for the future generation. The government has publicly announced the crisis and admitted its isolationist mistakes. As Cohen (1988) puts it,

Even as Bahasa Malaysia continues to be promoted and widely accepted as the national language and, as a new generation of students from ethnic-minority groups shows little trouble in speaking it -- the government has quietly begun to re-emphasize English (p. A29).

Thus with various factors at play it has become increasingly difficult for the government to move forward in implementing any sort of plan to improve the level of English proficiency. In theory, the government has ideas, but in practice, it is immobile with respect to language use.

Some officials now realize that the drastic measure of the National Language Act (1967) that made B.M. the only official language may have been a mistake. The Minister of Education, Anwar Ibrahim, commented that, "The mistake is that we thought we should be monolingual. Any decent young man - any graduate of an institution should be bilingual" (Cohen, 1988). Malaysia's Prime Minister Mahathir Mohammed also made a similar point in saying, "Refusal to acquire a command of English or some other language may well be a front hiding a weak personality that is terrified of exposure" (Cohen, 1988, p. A30). 


\section{CONCLUSION}

The language policies that the Malaysian government has implemented have had a wide ranging effect on language acquisition in West Malaysia. The National Language Act (1967), (macro policy goal) for example, has ultimately changed the structure and function of language used in West Malaysia. The change in structure and function of both B.M. and English has in turn affected language acquisition for all three ethnic groups. For example, the implementation of policies at the macro and micro level indirectly influences strategy use through learner variables, such as attitude and motivation. For example, the implementation of the National Language Act designated English only as a second most important language, thus making Bahasa Malaysia appear more important. It has only been recently that English has been promoted as an important language which influences the attitude of the people. The recent change in attitude towards English may have had an indirect influence on the strategies that Malaysian learners use. The more positive attitude towards the language may have directed their attention to their learning abilities in the acquisition of language learning, and thus motivated them to use such strategies as selfmonitoring, evaluating and reflecting harder on their learning processes. The three ethnic groups use of greater metacognitive strategies fit with the overall language situation.

Another example lie in the implementation of the methodology itself. In a highly structured method, learners who acquire a 
language based on specific rules of grammar are not encouraged to use conscious strategies. According to Tollefson (1981), a curriculum based on memorized rules does not facilitate unconscious acquisition of the language. He believes that acquisition is more likely to result, for example, from informal contact with native speakers, high quality instruction by teachers with native fluency or availability of reading materials and films.

There will be an incomplete understanding of how to interpret strategy use without an understanding of the language situation. Thus, I deemed it necessary to describe the language situation in West Malaysia with its macro and micro policy goals as well as its implementation on both levels, and how its implementation may affect language acquisition which ultimately affects strategy use of Malaysian learners. 


\section{CHAPTER II}

\section{REVIEW OF LITERATURE}

\section{INTRODUCTION AND OVERVIEW OF LEARNING STRATEGIES}

Recently, numerous scholars have begun to explore the way learning strategies influence the degree of proficiency obtained in a second language. Scholars such as Oxford (1989), Nyikos (1989), Wenden (1983a, 1985) and many others have carried out intensive research in the field of second language learning strategies. Oxford and Nyikos (1989) looked at variables such as motivation, sex, and years of study affecting the choice of language learning strategies by university students. The studies cited above have concluded that, in general, the better learners, that is those with a higher level of English proficiency, use a wider range of strategies than do those with a lower level of English proficiency.

This literature review is divided into four sections: 1) an introduction and overview of learning strategies, 2) theoretical models of second language learning, 3) empirical studies in language learning strategies, and 4) comparisons of inventories.

Since the 1970's, there has been recognition that in the field of second language learning there are some people who are more successful than others. From a theoretical as well as from a practical 
point of view, many researchers and teachers advocated learning more about these effective language learners. The identification of good language learners' strategies was thought to be extremely useful to the field. As such, linguists, educators and experts in the field have conducted extensive research (Naiman et. al., 1975, 1978; Rubin, 1975; Stern, 1974) that identified a whole set of strategies believed to be generally characteristic of good language learners.

In the 1980's, the focus turned towards the question of whether the number of strategies used by effective learners was really any different from those used by ineffective learners. Some researchers discovered that in actuality the number of strategies used by ineffective learners was not significantly different from the those used by effective learners (Vann \& Abraham, 1990). The focus of some research also changed from merely isolating or describing the strategies used by good language learners to describing strategies used by ineffective learners. More specifically, the researchers were interested in finding out what ineffective learners were or were not doing as compared to effective learners. Questions that arose from this shift of focus were the following:

1) What type of strategies did the unsuccessful learners use?

2) Were the unsuccessful learner's strategies any different from the successful learner's strategies?

3 ) Was the range of strategies used the same for both successful and unsuccessful learners? 
Some researchers (Chamot \& Kupper, 1989; Oxford \& Nyikos, 1989; Oxford,1989) have concluded that effective learners use a variety of appropriate strategies (such as metacognitive, cognitive, and social-affective) for different tasks. Strategy use also depends on learners' own stages of learning, attitudes, motivation level, personality, age, language learning goals, and national origin. Past research has also shown that 1) less effective learners use strategies less frequently, 2) less effective learners have a smaller repertoire of strategies, and 3) less effective learners do not choose appropriate strategies for the task. More proficient readers vary their strategies depending on the nature of the task and the context, while less proficient readers either deploy fewer strategies for the task or follow strategies that are not appropriate for either the task or the context (Chamot \& O' Malley, 1990).

In addition, researchers and teachers in the field of second language learning have been interested in the cognitive abilities that language learners use when acquiring another language. This interest is reflected in theoretical models of second language learning and acquisition which include learning strategies as one of the factors that influence second language learning, and will be discussed further on in this chapter (Bialystok, 1978; Stern, 1983). These models also point to how learners consciously intervene in their language learning.

Current techniques that are employed to gather information on the effectiveness of language learning strategies in the majority of 
strategy studies include observations, questionnaires, interviews, self-reports, diaries, and "think-aloud" procedures.

In general, it can be said that despite extensive research that has been conducted in the field of language learning strategies, it is still considered to be in its infancy (Huang \& Van Naerssen, 1987). Questions concerning the learning process and learner strategies remain. Despite the questions, the inventories of good learner strategies are helpful in providing insights into some of the common characteristics of successful learners as well as providing practical implications for language teaching and learning. The study of learning strategies is nevertheless far from complete, and is subject to modification through further research. In order to expand our understanding of second language learning processes of learners, Stern (1983) has suggested that it would be in the interest of researchers to further investigate different learning contexts, under different learning conditions, at different age and maturity levels and at different levels of proficiencies. In my study, several such dimensions have been added.

The literature on learning strategies in second language acquisition initially emerged from a concern for identifying the characteristics of effective learners, as mentioned earlier. Strategies used by 'good language learners' (Rubin, 1975; Naiman et. al., 1975; Stern, 1974) or strategies that ineffective learners do not use or use less of were identified and documented through procedures such as observations, self-reports, and diaries. These efforts showed that 
most students were active learners who applied strategies to certain tasks/activities.

Naiman et. al., (1978) proposed a classification scheme of their own. Their scheme contained five broad categories of learning strategies: 1) an -active task approach, 2) realization of a language as a system, 3) realization of language as a means of communication and interaction, 4) management of affective demands, and 5) monitoring of second language performance. As can be seen, Naiman et. al.'s, classification scheme is different from Rubin and neither classification scheme appears grounded in theories of second language acquisition or cognition.

O' Malley et. al., (1985) believe that one of the more important findings is the formulation of strategies in an information-processing, theoretical model. This model includes the metacognitive and cognitive functions.

Metacognitive strategies involve thinking about the learning process (reflection), planning for learning, monitoring of comprehension or production and self evaluation. Some examples of metacognitive strategies are focusing attention, consciously searching for practice opportunities, planning for language tasks, selfevaluating, and self-monitoring. Brown (1982) distinguishes metacognition as knowledge and regulation of cognition. Knowledge about cognition involves conscious access to one's own cognitive operations and reflections, whereas regulation of cognition involves planning (eg., predicting outcomes), monitoring (eg., testing, revising) 
and checking outcomes (e.g., evaluating the outcome of any strategic action in terms of criteria of efficiency).

Cognitive strategies, on the other hand, are more directly related to individual learning tasks and require direct manipulation of materials, for example, reasoning, analyzing or summarizing.

Oxford (1990) has developed a list of six broad strategy categories as mentioned earlier. There are metacognitive, cognitive, affective, social, memory, and compensation strategies. The definition of metacognitive and cognitive has already been discussed. The rest of Oxford's strategy groups are further discussed.

Affective and social strategies are closely connected in that they involve learners learning to control their emotions and attitudes. This involves anxiety reduction, self-encouragement or asking questions from others and generally becoming culturally aware.

Memory strategies involve grouping, imagery and structured review. Memory strategies help place information into memory and to recall it when needed.

Compensation strategies such as guessing meanings intelligently and using synonyms or other production tricks when an expression is unknown.help the learner to overcome knowledge limitations

Chamot and O' Malley (1990) maintain that students who do not use metacognitve strategies are at a disadvantage, for they become essentially learners without direction since they do not plan their learning or monitor their progress. This line of research 
suggests that the transfer of strategy training to new tasks/activities may be best accomplished by combining metacognitive and cognitive strategies.

\section{THEORETICAL MODELS OF SECOND LANGUAGE LEARNING}

Bialystok (1978) and Stern (1983) have proposed theoretical models which are similar to each other in that both attempt to show how various variables influence learning strategies. However, the variables themselves are different from each other. Bialystok's (1978) model, for example, shows how by modifying or altering the 'input' level (language that is experienced), different types of strategies are optionally employed by the learner, such as inferencing, formal and functional practicing and monitoring (see Figure 1).

Formal practicing refers to what language learners do to increase their explicit knowledge or to acquire new information about the language. Functional practice refers to increased exposure to the language for communication. Monitoring refers to the linguistic knowledge that is applied to the learning or communication task in order to correct responses (e.g., learners reread what they have written and identify grammar errors). Inferencing is a strategy in which several possible sources are exploited before arriving at some explicit information (e.g., learners refer to a speaker's gestures and the topic of the discourse to understand). 


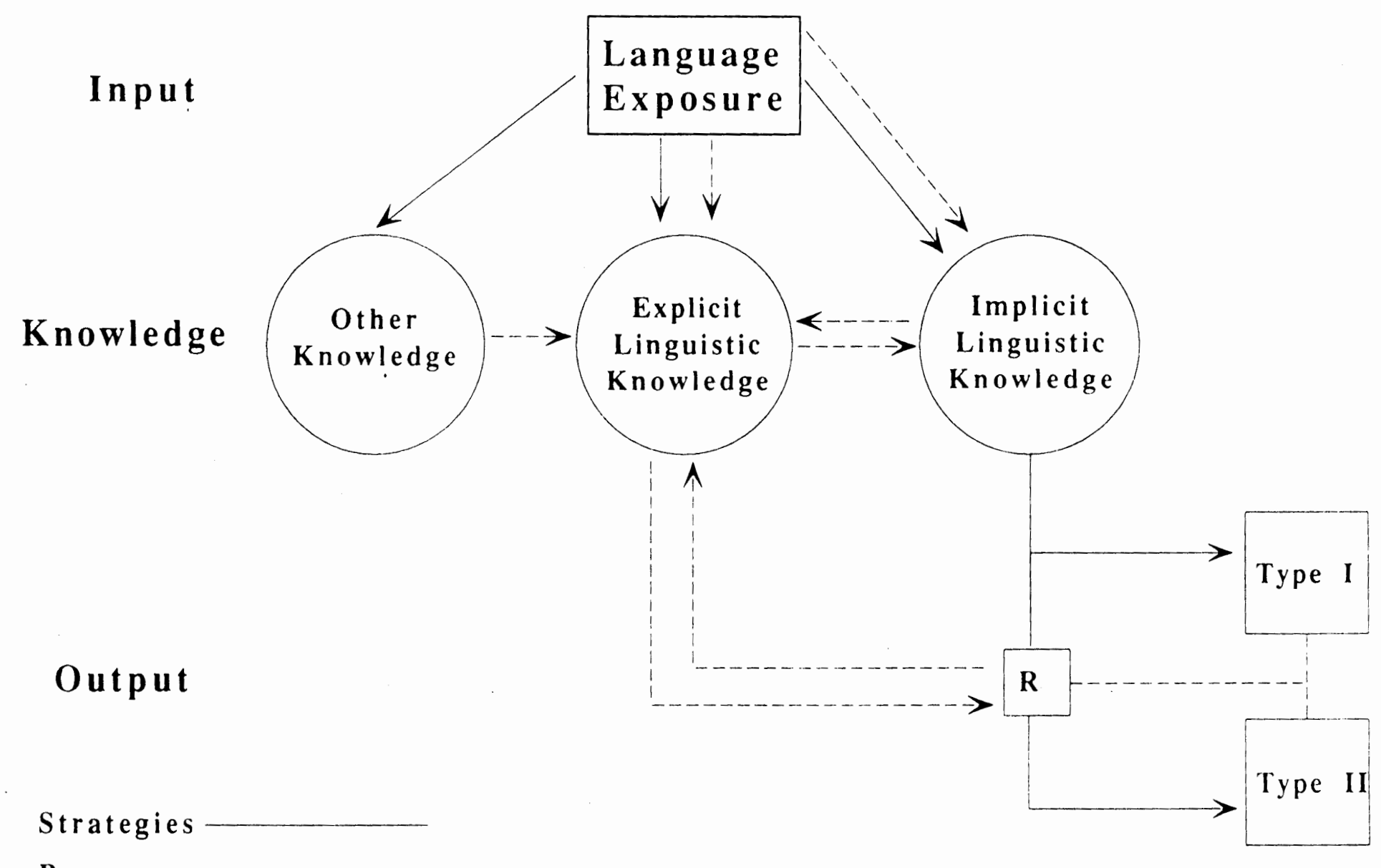

Figure 1. Bialystok's (1978) Model of Second Language Learning. 
Bialystok (1978) demonstrates that the use of these strategies has positive effects on achievement in certain kinds of tests and that all strategies except monitoring have a significant effect for all tasks.

Stern's (1983) model, on the other hand, shows how every variable, such as; social context, learner characteristics, or learning conditions, has an effect on the learning process, which consists of learning strategies (p. 338). The learning process, which consists of strategies, techniques and mental operations, is determined by learner characteristics and by learning conditions (see Figure 2). Stern distinguishes between learner strategies and learner techniques. In his opinion, learner strategies are described as an overall characteristic of approaches employed by language learners, whereas learning techniques are the observable learning behavior that is consciously employed by learners (eg., looking up words in a dictionary). Stern believes that language learning is a developmental process of proficiency, of formal and semantic knowledge, of communicative capacity, and of creativity. The learning process, according to Stern, can be best understood when it involves the learner intellectually/cognitively, socially, and affectively. From here, Stern derives four sets of strategies that he thinks good learners will employ while less efficient learners will employ the same strategies but not as often. Sets are as follows:

1) active planning strategies (i.e: good language learners will select goals, recognize stages and developmental sequences, and actively participate in the learning process). 
2. Learner characteristics

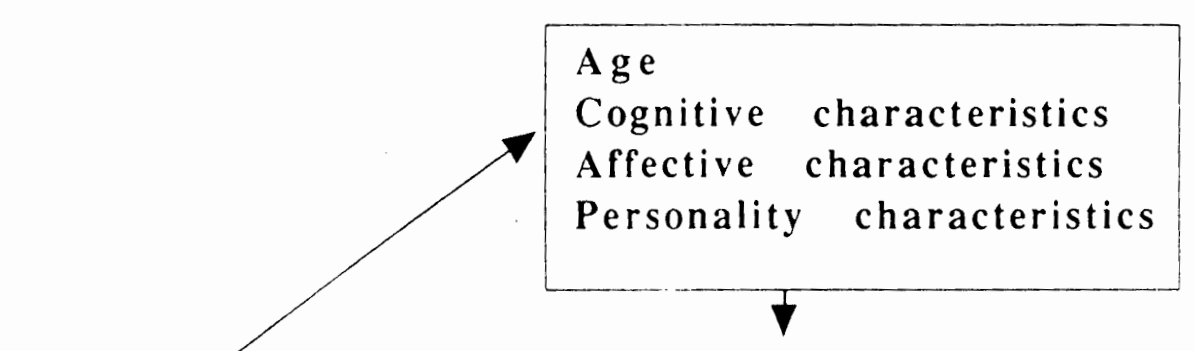

4. Learning process

5. Learning outcomes

1. Social context

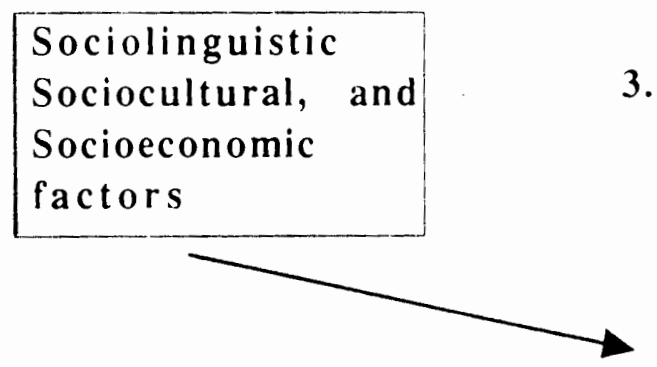

Strategies, techniques and mental operations

2

3. Learning conditions

\begin{tabular}{|lc|}
\hline e.g: EFL & e.g: ESL \\
Educational & Exposure \\
treatment: & to target \\
Objectives & language \\
Content & in its \\
Procedures & natural \\
Materials & setting \\
Evaluation & \\
\hline
\end{tabular}

L2 competence/

proficiency

Theoretically based schemes

Impressionistic

ratings

Test performance

Interlanguage

Figure 2. Stern's (1983) Model. 
2) "academic" (explicit) learning strategy. (i.e: developing the necessary techniques of practice and memorization, monitoring own performance and revising).

3) social learning strategy (i.e: seeking communicative contact with target language users, active participants in authentic language use).

4) affective strategy (i.e: coping effectively with the emotional and motivational problem of language learning).

\section{EMPIRICAL STUDIES IN LANGUAGE \\ LEARNING STRATEGIES}

The classic inventory by Rubin (1975) identifies the "good" language learner. Her list of the seven strategies used by good language learners, while extremely helpful in determining what strategies good language learners possess, is very general and does not specifically identify the actual strategies used. She believes that what constitutes a good language learner is possession of these seven strategies - a willingness to guess and ability to guess accurately, a strong drive to communicate, a lack of inhibition, an attention to form, a desire to practice consistently, a monitoring of one's own and others' speech and an attention to meaning. There are certain drawbacks to Rubin's list which will be discussed later in this chapter. Nevertheless, these strategies have been used as a basis for further research. 
Rubin's (1975) discussion of the concept of good language learners occurred independently from the cognitive theoretical developments that dominated the late 1970's and which continue to influence the 1980's. Her work also opposed the linguistic view of the time that good language learners simply had a good "aptitude" for language learning.

Since her 1975 publication, she has carried out other studies exploring cognitive processes in second language learning. In 1981, she began a process of collecting data on the cognitive processes and strategies used by language learners. She used a variety of procedures to identify learning strategies, such as observations, student self-reports, videotapes of classrooms, strip stories (reasoning tasks in which a group of students assembles a complete story when each has been given only a single sentence out of context) and directed diary studies. Rubin (1981) recognizes the limitations in observing and eliciting cognitive strategies and reports these limitations or difficulties suggesting:

1) Observation was not very productive, since teachers usually focused on getting the right answers and not on the process by which students derived the answers.

2) Some students needed to be tutored to report on their cognitive strategies used in language learning.

3) Some students seem better at reporting cognitive strategies than others. 
Based on her analysis, Rubin identified some of the major cognitive strategies that may contribute directly and indirectly to learning, which will be further discussed in this chapter.

Another inventory is Stern's (1974) list of ten strategies used by the successful language learner, which reflected his own experience as a language teacher and learner. Stern's list, based on and partly adapted from Rubin's (1973) work, is more in-depth and is derived from the arguments he had set forth concerning language learning. Stern's list of ten strategies has been verified and documented by other researchers (Reiss, 1981; Pearson, 1988; Wenden, 1983b). Stern's strategies as discussed by Reid (1981) and Pearson (1988) include the following:

1. a higher \& more flexible ability to adjust to new conditions

2. an active approach

3. an outgoing, open \& tolerant approach

4. an attention to form

5. a methodical but flexible approach

6. an individual who searches for meaning

7. a willingness to practice the language

8. a willingness to use language in real communication

9. a self-monitoring of one's own learning process

10. an internalization of one's own learning process

In an attempt to develop learners' strategies, Stern thought it was important to understand how form, meaning, communication and creativity influence language learning. For example, in form, he 
saw that learner's knowledge of the English language was not conceptual or analytical, but global and intuitive. In the mastery of linguistic form, language is not handled as a mix of separate items, but as an ordered system. In meaning, he believes that there is a fusion of form and meaning. Native speakers take form for granted and focus on meaning. When we speak, listen or read we want to express ourselves in meaning and get at meaning. He argues that in verbal communication, we use language with maximum attention to communication and minimum attention to form. In creativity, he maintains that competence is dynamic and active, not mechanical or static, and we constantly adjust our language use according to situations and circumstances (Stern, 1974).

Other research has also focused on how affective variables influence the various types of strategies used and thus contribute to the success or failure in learning a second language (Oxford \& Nyikos, 1989; Brown, 1973; Reiss, 1981). The findings have indicated that a more positive attitude, for example, towards the task at hand and towards the culture, leads to an increase in language proficiency.

Research in second language learning refers to the general overall characteristics of a learner's approach to language learning. Wenden's (1983a) definition of what makes a good language learner includes learners who attend to form as well as to meaning; they attempt to develop the target language into a separate system, and generally, have a tolerant and outgoing approach to the target language. 
One of the main questions that continues to be emphasized in the early studies of learning strategy is the definition and classification of strategies. Wenden (1983a) believes that it is important that classification schemes such as Rubin's (1981) continue to be refined. One refinement possibility is to add metacognitive strategies that deal more with reflections on the process of learning to the rest of Rubin's strategies which deals mainly with direct manipulations. Wenden's (1983a and 1987) work focuses on metacognitve strategies that could be added to the earlier classification scheme of strategies.

One of the most prolific researchers who has contributed widely to the field of learning strategies in the past decade has been Rebecca Oxford. Her most recent book, Language Learning Strategies: What Every Teacher Should Know (1990), mainly targets teachers of second or foreign languages. She believes that it is useful for teachers to help students become more active and self-directed when acquiring a second or foreign language. Her text provides various ready-to-use or ready-to-adapt strategy games covering all four language skills (reading, writing, listening and speaking) to be used with students and is extremely helpful in providing teachers with hands-on-experience in teaching strategies.

Oxford (1990) has also devised a clear, precise and elaborate strategy classification system that covers six main types or categories of strategies, which are further divided into direct and indirect strategy classes based on the synthesis of earlier work on good language learning strategies from Stern (1983) (see Figure 3 \& 4). 
A set of general instructions and two strategy inventory instruments are included in Oxford's (1990) Language Learning Strategies book. The first is a set of general instructions for the administrator. One SILL version is for English speakers learning a new language and the other is for speakers of other languages learning English. Both of these have been devised by Oxford in order to identify and diagnose students' learning strategies. Oxford (1988) and other researchers (Oxford \& Ehrman, 1989; Oxford \& Nyikos, 1989) attempt to discover how some learners of different language, cultural, educational or gender background use certain strategies.

Oxford et. al., (1989) use particular versions of the SILL with a range of subjects from different settings and backgrounds, but so far none of the investigations has been from the Pacific Rim region. Thus it was interesting to use Oxford's SILL inventory (the translated version) for my study since this was the first of its kind in West Malaysia.

\section{COMPARISONS OF INVENTORIES}

Rubin (1975), as mentioned earlier, offers some good insights into the cognitive processes that seem to occur in good language learners. She isolates and studies successful language learners' strategies and she links certain strategies that learners must possess in order to be categorized as "good language learners." The disadvantage is that learners looking at her work will immediately try to categorize themselves as either successful or unsuccessful 

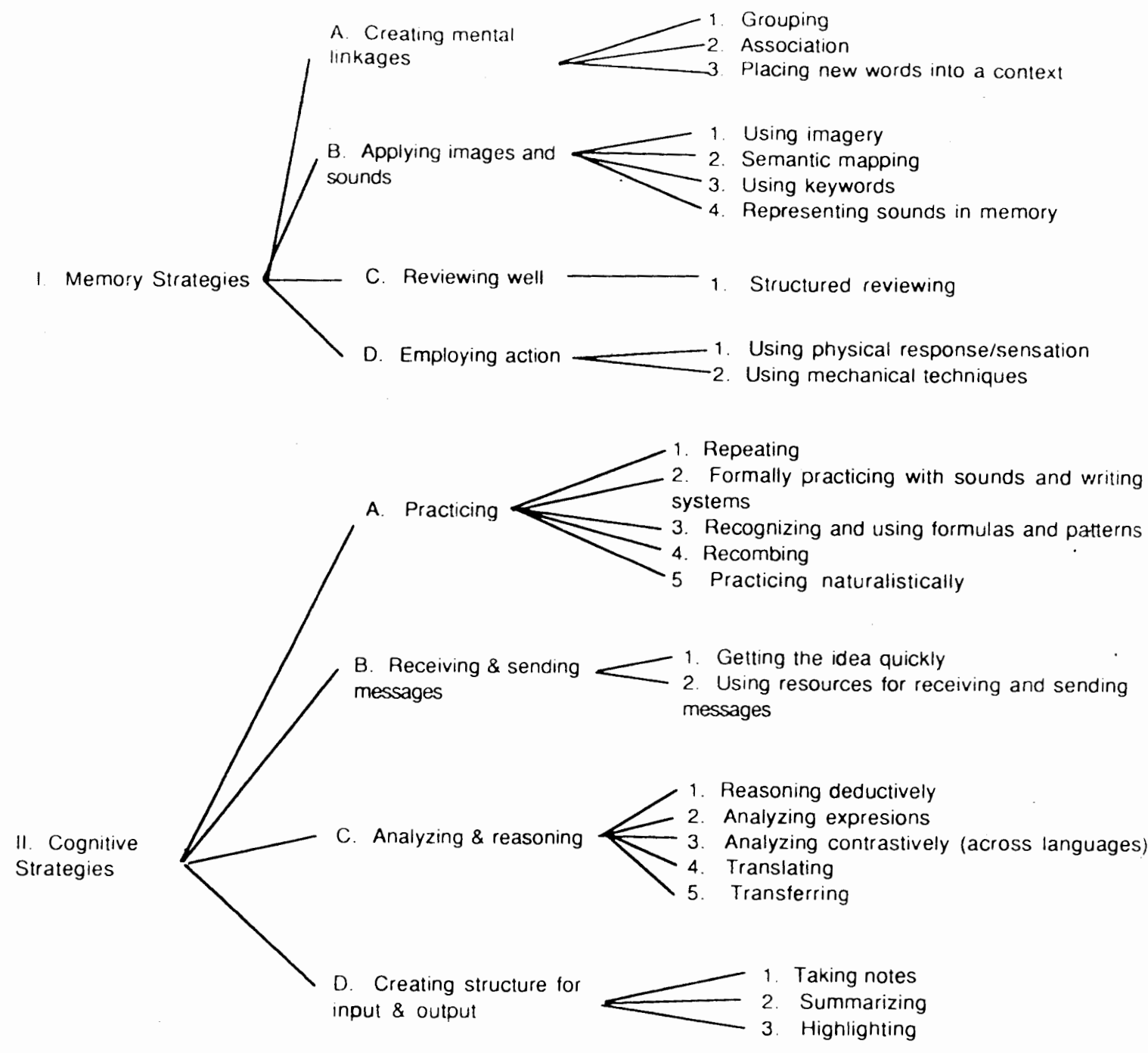

III. Compensation strategies

A

A. Creating mental

2. Association

3. Placing new words into a context

2. Using mechanical iechniques

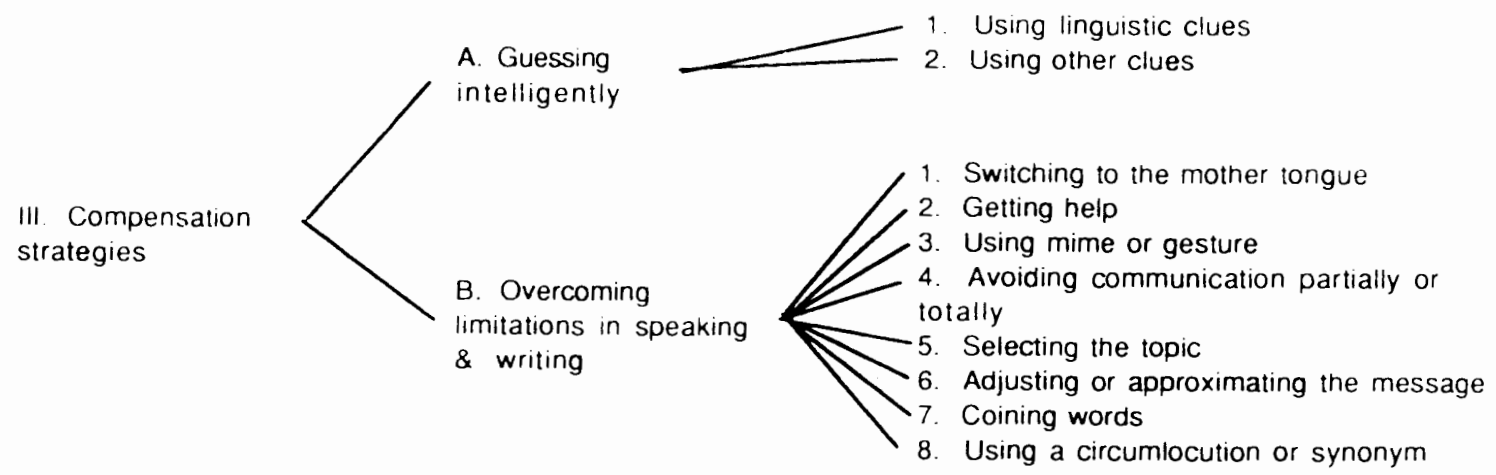

Figure 3. Oxford's Direct Strategies. 

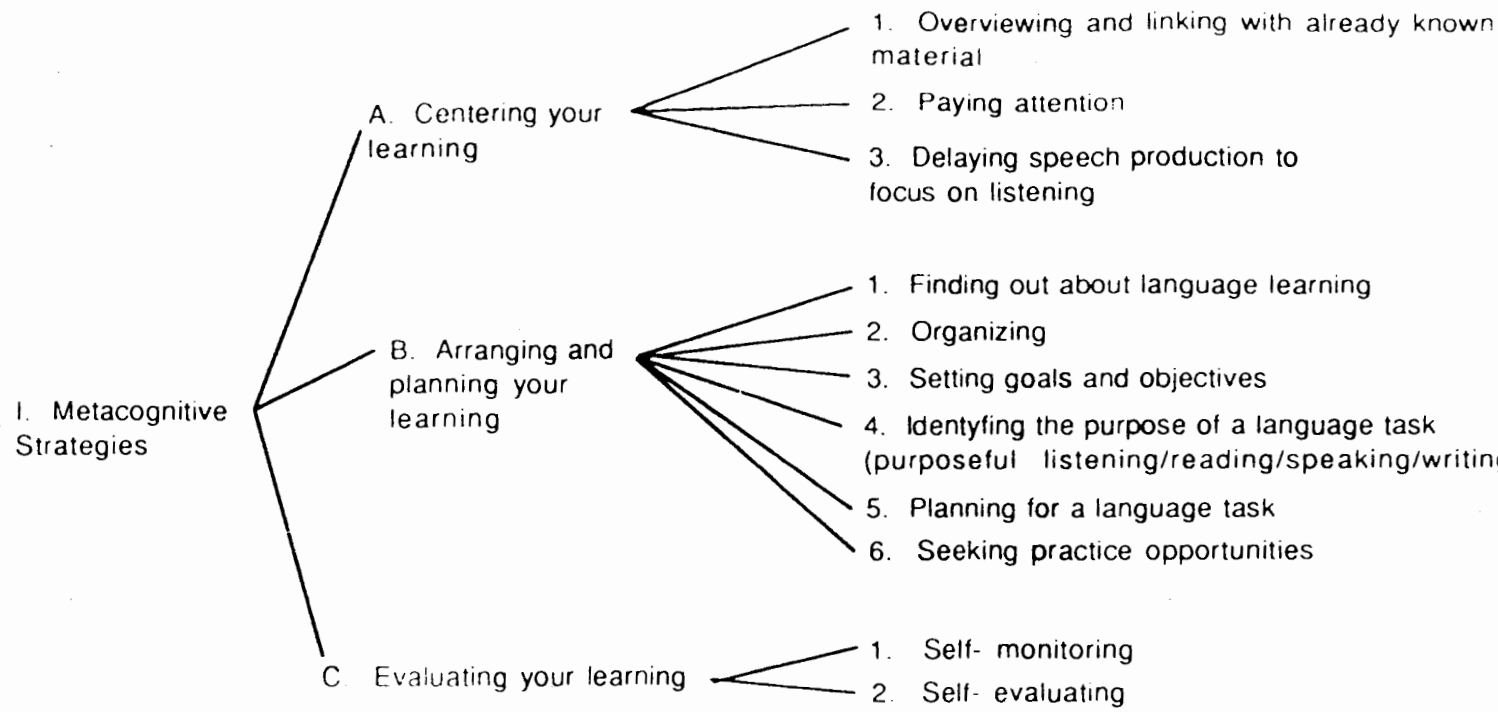

3. Setting goals and objectives

4. Identyfing the purpose of a language task (purposeful listening/reading/speaking/writing)

5. Planning for a language task

6. Seeking practice opportunities

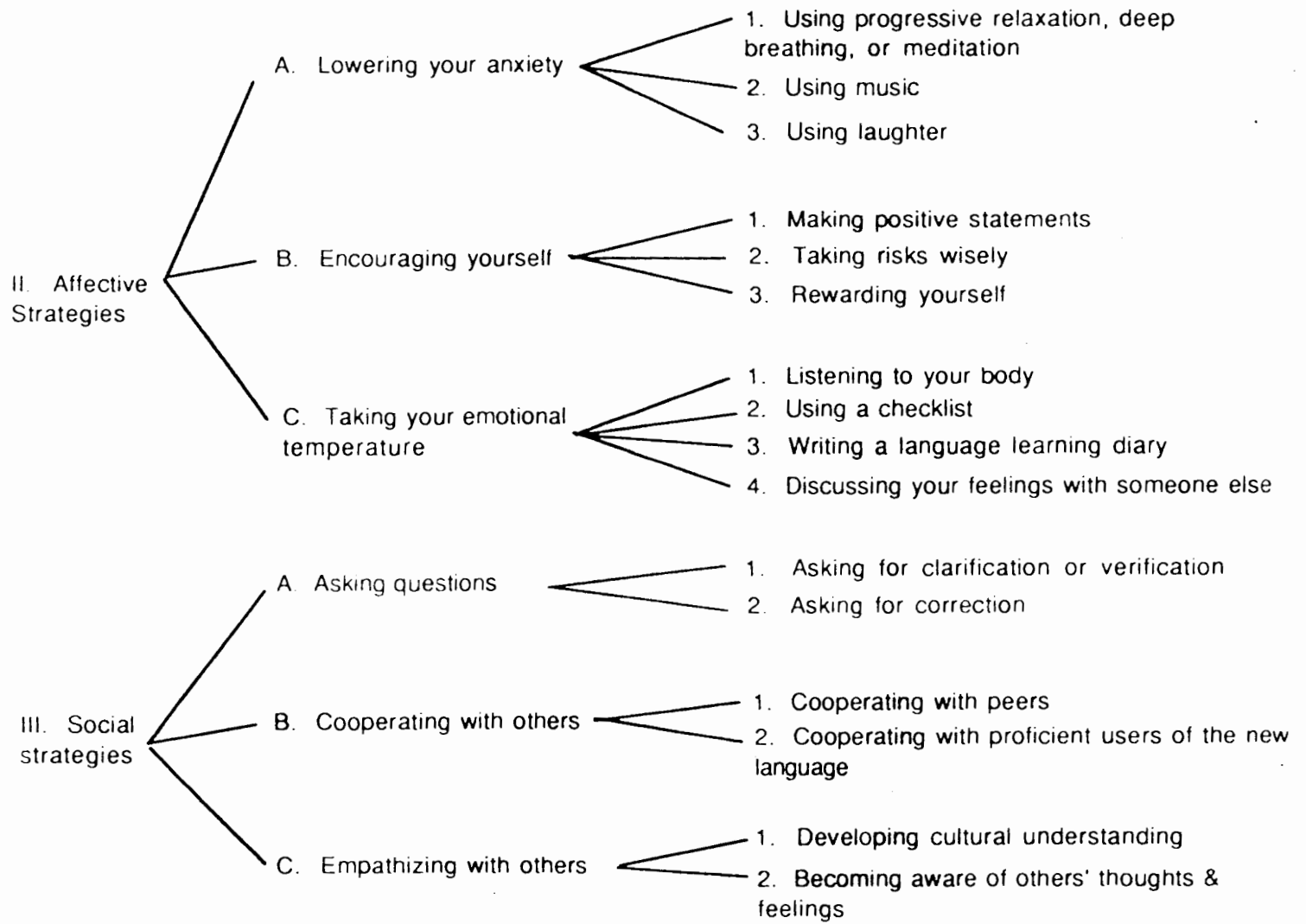

Figure 4. Oxford's Indirect Strategies. 
language learners. They will also tend to view the strategies as either 'good' or 'bad' or 'right' or 'wrong'. These learners may forget that Rubin's work accounts only for the general characteristics of learners and not specific characteristics of individual's learning strategies, since her list of seven strategies which a good learner should possess is broad. Her approach is not exhaustive enough to account for individual differences, and focuses on only one type of student. Furthermore, she does not have any guidelines or advice for teachers on how to help students use certain strategies.

Stern's (1974) list of characteristics of successful language learners is similar to Rubin's only in that it tries to categorize good language learners and the strategies that they are likely to use compared to less efficient learners. However, unlike some researchers (Rubin 1975; Naiman, et. al., 1978), Stern recognizes the fact that there may be a combination of strategies used by all learners, and that not all learners employ all strategies equally and at all times. He also admits that he has listed the ten strategies in a simplified manner when contrasting effective and ineffective learners, even though in reality, there may be a combination of more than one characteristic. In addition, he recognizes the fact that learners of different languages, educational and cultural backgrounds, and of different ages and maturity levels are likely to learn languages with different emphases on one or the other strategy and with different degrees of skill in applying these strategies. Stern's contribution to the study of strategies is important and have had significant impact on how learner's strategies are viewed and in 
assisting further research. Researchers today, for example, can build upon his definition of what strategies make a good learner just as he did with Rubin's (1975) work.

Oxford (1990), on the other hand, provides a more detailed, comprehensive and exhaustive outline of strategies as well as a guideline of strategies for teachers to use in their classrooms. She tries to create knowledgeable teachers and users of learner strategies, and strives to demonstrate that learning strategies do not occur in isolation, but they interact with other factors. She also does not try to link the strategies to a certain group of students, but rather she evaluates gender, age, and attitude differences in relation to type and amount of strategies that are used (Oxford \& Ehrman, 1989; Oxford, 1988). Oxford also does not make any distinction between effective and ineffective language learners. To her, there is no distinction, no right or wrong strategies, no successful or unsuccessful learners; just learners using strategies to help themselves improve their language proficiency. She sees learners as individuals, not in terms of groups. 


\section{CHAPTER III}

\section{METHOD}

\section{INTRODUCTION}

This chapter reviews the procedure and rationale used in the selection of subjects, and the instrument and data collection as well as the manner in which the successful and unsuccessful learners were chosen.

I attempted to select subjects who came from classes of high and low achievers so that there would be more of an equal distribution of successful and unsuccessful learners. Two types of variables were chosen when deciding to administer the test on the subjects: ethnicity (Malays, Chinese, and Indians) and performance (successful and unsuccessful).

\section{PARTICIPANTS}

Subjects

Two Malaysian English language teachers administered Oxford's Strategy for Language Learning (SILL) questionnaire to two Malaysian secondary classes where English was a compulsory language. 
The subjects in the study were from two secondary Form four students, which is comparable to the American Grade 10 high school level. The two classes were randomly selected by the teachers, but one class was tracked in a higher academic standard than the other. In West Malaysia, students are ranked according to their academic grades. Hence the higher achievers are separated from the lower achievers. There are on average about ten classes in one form/grade; therefore, there are approximately five higher achieving classes and five lower achieving classes. Thus, in the selection of subjects, I left it up to the teacher to select a high achieving class and a low achieving class, from a total of ten possible classes. This was done in order to obtain as equal a number as possible of potentially successful and unsuccessful students.

The subject group was selected for several reasons. First, the subjects were willing to participate in the study. Second, there was a mix of ethnic background (Malays, Chinese, and Indians) and a mix of successful and unsuccessful students. Third, the classes consisted of a large number of students. Fourth, the teachers were very cooperative and reliable in administering the study as well as returning the results back to me.

Accompanying the questionnaire (which had been translated into B.M.) was a list of instructions. The list of instructions basically led the subjects through the questionnaire in a step-by-step method. In addition, a separate list of instructions was given to the administrators that explicitly explained how the questionnaire should be administered. 
The research purpose was briefly explained to the subjects but the focus on the comparisons of learning strategies between the two different variables (ethnicity and performance) was not revealed to ensure that their behavior would not be altered in any way (see Table 1 for overview of the subjects involved).

\section{TABLE 1}

\section{OVERVIEW OF MALAYSIAN SUBJECTS}

$\begin{array}{lclcc}\text { Ethnicity } & \underline{N} & \text { Ethnicity } & \text { Successful } & \text { Unsuccessful } \\ \text { Malay } & 27 & \text { Malay } & 5 & 22 \\ \text { Chinese } & 24 & \text { Chinese } & 40 & 7 \\ \text { Indian } & 24 & \text { Indian } & 18 & 6\end{array}$

Subjects for Analysis

There were originally a total of 99 Malaysian subjects, but one was dropped from the study because she had not filled in her ethnicity in the background questionnaire. Hence, there was no way to categorize her into any ethnic group. Therefore, the data from 98 (out of 99) Malaysian students was used for analysis. Of the 98 subjects, 47 were Chinese, 24 were Indians and 27 were Malays. And of the 47 Chinese, 40 were considered successful and 7, unsuccessful; 18 Indians were considered successful and 6, unsuccessful; 5 Malays were considered successful and 22 unsuccessful. All students who participated in the study were 16 years old and female. The students came from different cultural and linguistic backgrounds. Many of them spoke more than one language 
at home. Of the 47 Chinese, 9 spoke only English, 4 spoke only Chinese, 31 spoke Chinese and English, 2 spoke Chinese, English and Malay and 1 spoke English and Malay at home. Thus in the categorization of language, of the 27 Malays, 17 spoke only Malay and 10 spoke Malay and English, and in the categorization of language, of the 24 Indians, 1 spoke only Indian, 1 spoke Indian and Chinese, 6 spoke Indian and English, 1 spoke only Malay, 14 spoke only English and 1 spoke English and Malay (see Figure. 5, $6 \& 7$ for a full breakdown of language categorization).

\section{The administrators}

The chief administrator selected the second teacher to administer the questionnaires in one of the two classes. The proficiency level of the students was judged by the teachers, that is, whether the subject was considered successful or not. The teachers were asked to make a distinction between successful and unsuccessful learners based on certain criteria - the teacher's years of experience teaching English, and appropriate knowledge about the student's work in class. A mutual agreement by the teachers had to be reached before a student was considered successful or not. This was to ensure high reliability in their judgement. The distinction being made based on these two criterias was necessary since the standard government examinations for English were considered unreliable by the teachers. Due to the politics involved in West Malaysia, the government had lowered the standard of English for everyone. Hence, a student that was actually not successful in 
English could easily pass the standard exam. Therefore, an additional evaluation by the teachers of each student's rate of success lends credibility to the categorization of how successful the learners are.

\section{INSTRUMENT}

The instrument used was a self-reporting questionnaire, the Strategy Inventory for Language Learning (SILL) developed by Oxford (1989) to discover learning strategies of students. It consists of six major strategy groups (memory, cognitive, compensation, metacognitive, affective, and social,) with a total of 50 questions. On a separate SILL Worksheet, students were requested to mark down their answers on a scale of 1 to 5 , with sufficient response options: never or almost never true of me, usually not true of me, somewhat true of me, usually true of me, always or almost always true of me.

In keeping with use of Human Subjects guidelines, no personal information was collected that could be traced to a particular individual. The students were required to write their names on the bottom of the last page of the background questionnaire. This was necessary in order that the teachers could judge who was successful and who was not. After they were identified as successful or not, their names were deleted from the questionnaires by detaching the last section with their names on it. Information that was collected consisted of student ethnic background, native languages, other languages, gender, age, and reasons for studying English. The subjects were given the translated B.M. version (see Appendix A \& B 



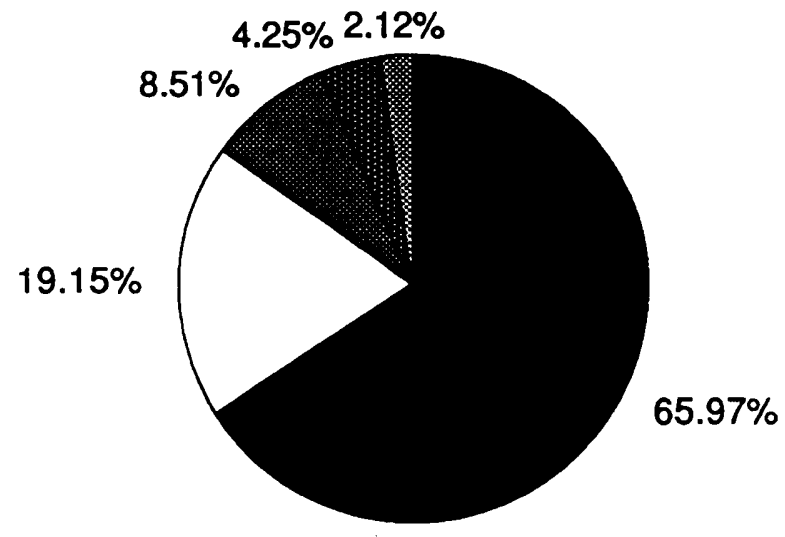

English \& $\square$ English $\square$ Chinese Chinese English \& Malay Malay

Figure 6. Forty seven Chinese Learners. 


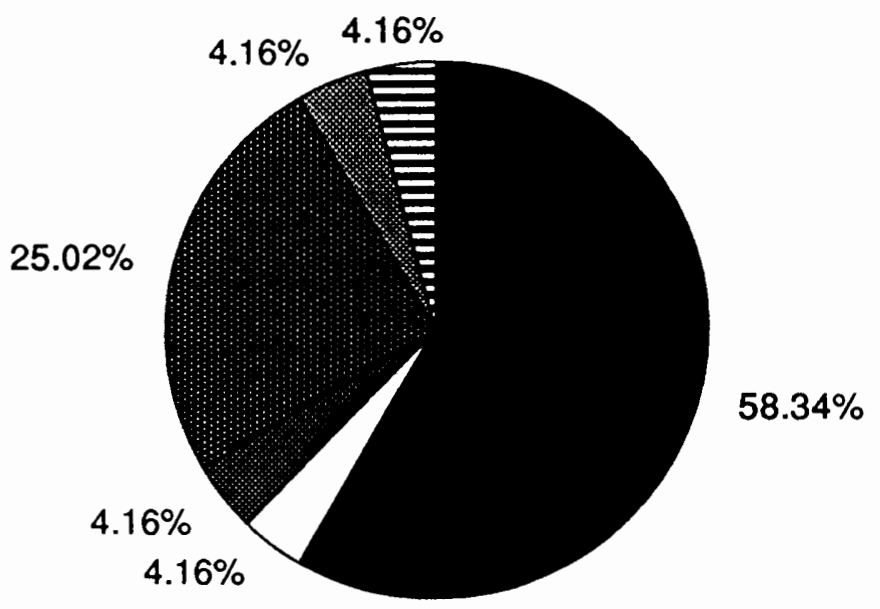

English \&

$\square$ English

Chinese

Chinese

眮 Chinese, English English \& Malay

\& Malay

Figure 7. Twenty four Indian Learners. 
for background questionnaires of the English and B.M. version respectively).

In order to eliminate English language proficiency as a confounding variable, the SILL was translated into B.M. by one translator and back-translated by another translator. Both translators were native speakers of B.M. (see Appendix C \& D for the SILL and the SILL translated version respectively). There were some words that could not be easily understood by Malaysian learners for there are not commonly used. A list with its translation was made and attached to the end of the SILL for easy reference (see Appendix E).

\section{DATA COLLECTION}

\section{Procedure}

In order to collect the data, I had made previous contact with one of the two teachers and had explained the purpose of my study to her. The English teacher was willing to administer the SILL in class. In hopes of obtaining an equal number of successful and unsuccessful learners, a high achieving and a low achieving class were chosen. However, data from which classes exactly the students came from was not collected. It is not possible to distinguish which classes the successful and unsuccessful learners actually came from. Thus, there cannot be an automatic link between high and low achievers with successful and unsuccessful learners in classes. 
The SILL and the background questionnaires were distributed to the students. The administrators were given a teacher's copy which included the questionnaire and a list of instructions as to how to conduct the study. The purpose of the study was briefly explained and then the questionnaires were handed out. Learners were allowed to opt out of the study if they wished. The learners were also told that participation in this study would not affect their grades during their normal course of studies in any way. This was necessary to ensure that their responses to the questions would be honest and accurate. Two sections in the SILL questionnaire were optional for the learners, the "Profile of Results on the Strategy Inventory for Language Learning (SILL)" and the "SILL Profile of Results (graph form)". Both these sections were targeted for the benefit of the students if they wanted to know what strategies they were using and at what frequencies. The study took approximately 45 minutes, one English period. After the data were collected, the teachers divided the learners into successful or unsuccessful. If a learner was considered successful, an ' $S$ ' was written at the bottom of the background questionnaire in the space specifically provided for the teacher. Likewise, if the learner was unsuccessful, a ' $U$ ' was written. This was done separately by both teachers. Then, after the ranking was completed, both the teachers compared rankings and came to a consensus There were no disagreements. The results were then mailed to me.

Upon receipt of the results, I checked through all the scoring sheets which tallied their sum and mean for each strategy as well as 
the overall mean for mistakes. All subjects had completed their scoring sheets which identified the amount and frequency of strategies that they used.

The data from the questionnaires were statistically analyzed. The data analyzed included native language, age, mean scores of strategies used, ethnicity, and performance. The mean scores were used to compare the frequency of use for each strategy in each ethnic group. The Kruskal-Wallis and the Mann-Whitney $U$ tests were used in order to detect significant differences between groups. In order to find out if the differences in mean scores were significant, the $p$ value was calculated. If $p$ value was less than and equal to .05 , then the differences in mean scores were significant. That is, the significance level was set at less than or equal to .05 . These tests are non-parametric statistical tests. This is appropriate as the data do not meet the assumptions of normality and homogeneity, of variances required for use of parametric statistical tests. The Kruskal-Wallis test was run on successful and unsuccessful students and the Mann-Whitney $U$ test was run on the three ethnic groups.

In order to answer research question \#5, it was necessary to understand the meaning of Stern's strategies. This was a difficult task to do since his strategies were rather broad and subjective and therefore open to interpretation. For example, one of Stern's strategies was "an active approach". "An active approach" can cover many of Oxford's strategies since it is such a broad term. In addition, as Stern explains, his strategies are general tendencies of overall 
characteristics by learners, whereas learning techniques are reserved for observable learning behavior, such as study habits, or detailed procedures, such as looking up words in a dictionary.

In order to compare Stern's strategies with Oxford's strategies, I had to first select the strategies used most often by only the successful learners from all three ethnic groups. My definition of what makes the "most often used" strategies were scores of 4 or 5 , since they were the most frequently used according to Oxford's (1990) SILL inventory. For example, score \#4 indicates "generally true of me" and score \#5 indicates "always or almost always true of me". Scores \#1, \#2 and \#3 indicate that the learners do not use the strategies very often since they range from "never or almost never true of me" to " somewhat true of me".

Hence, from looking at their SILL scoring sheets, strategies that indicated a score of 4 or 5 were selected. These strategies were noted for each successful learner in two columns by "subjects" and "statements/strategies used most often" (see Appendix F).

After this was completed for each successful learner, on a separate sheet of paper, I created two columns labelled "statements/strategies" and "frequency of most strategies used". On the first column, I listed all 50 possible statements/strategies according to Oxford's SILL inventory. Then using the strategies that were noted previously from "statements/strategies used most often" for successful learners, strategies used most often were transfered and recorded under the second column of "frequency of most 
strategies used", which represented "frequency of strategies used most often".

For example, if the first successful learner had strategies/statements $2,3,10,14$ and so on scored as 4 and 5 , these particular strategies were tallied into the second column of the second sheet of paper indicating "frequency of strategies used most often". So, for any strategy, the highest possible frequency could be 63 since all 63 successful learners could in practical terms have chosen a particular strategy as "used most often".

Not all strategies that were ranked 4 or 5 were actually used by that many learners. Certain strategies stood out more than the rest in terms of frequency used. That is, for some strategies only a few of the successful learners indicated they used them often, yet for other strategies more learners indicated they used them often. For example, for strategy \#5, (I use rhymes to remember new English words) only 3 learners scored it a 4 or 5 , whereas for strategy \#15, (I watch English language TV shows spoken in English or go to movies) 61 successful learners gave it a 4 or 5 .

As such, I found that even though certain strategies were scored by some learners as "generally used most often" or "used most often", not all of them were worth taking note of. Hence, I disregarded those strategies that were not used by many of the successful learners even though they had scored them a 4 or 5 . I considered any frequency above a score of 20 to be the strategies used most often by all three successful ethnic groups since this accounted for one third of the total possible amount of successful 
learners (63). Figure 8 illustrates the number of strategies used by Malaysian learners and any number higher than 20 was considered most often used strategies (see Figure 8). The most common strategies were used to compare those with Stern's 10 strategies for good language learners (see Table II). 


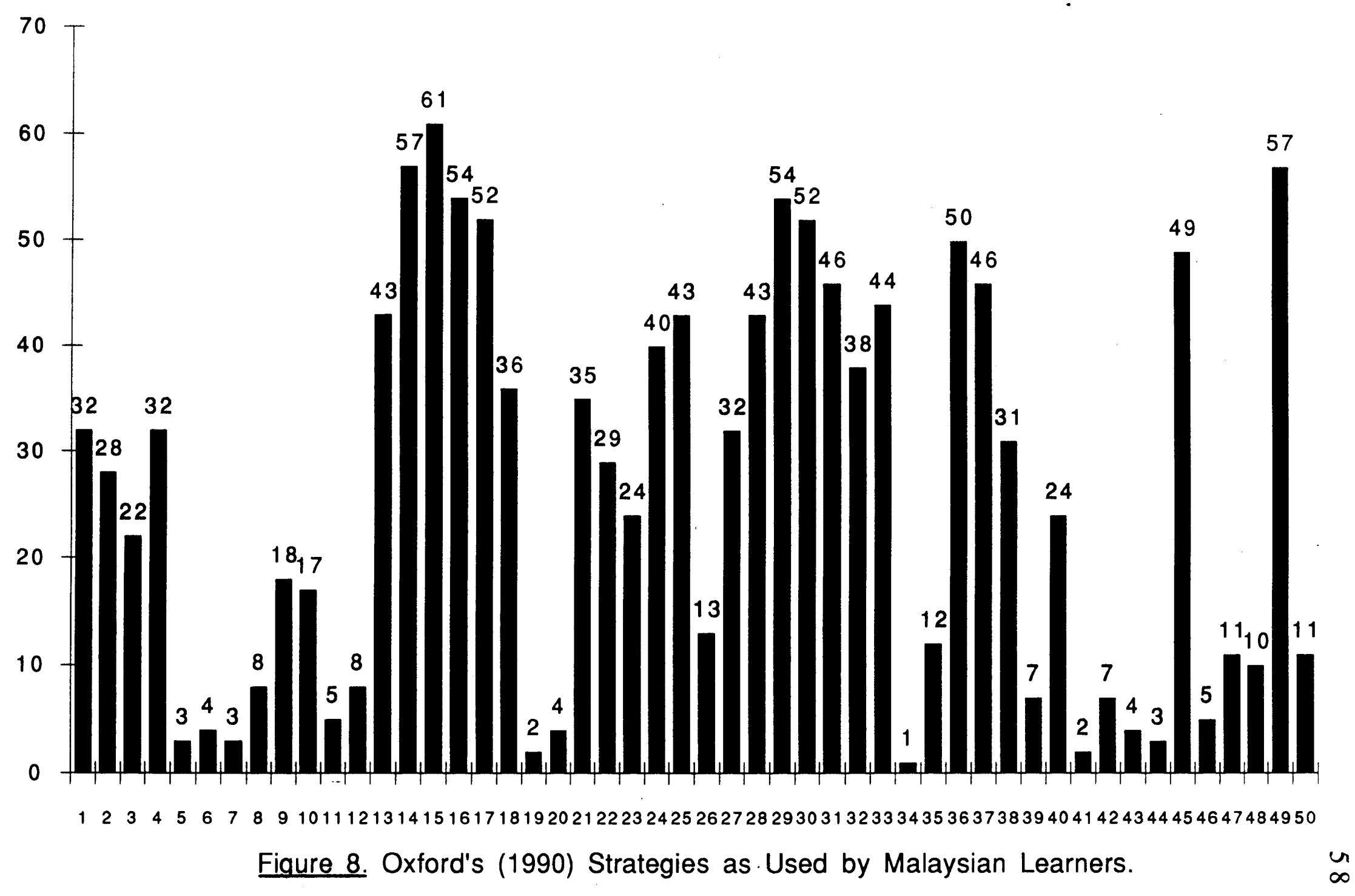


COMPARISON OF OXFORD'S STRATEGIES AND STERN'S STRATEGIES

\begin{tabular}{|c|c|}
\hline Oxford's Strategies & Stern's 10 strategies \\
\hline $\begin{array}{l}\text { 1. I think of relationships } \\
\text { between what I already know } \\
\text { and new things I learn in English. }\end{array}$ & $\begin{array}{l}\text { 1. a higher and more flexible } \\
\text { ability to new conditions }\end{array}$ \\
\hline $\begin{array}{l}\text { 2. I use new English words in a } \\
\text { sentence so I can remember } \\
\text { them. }\end{array}$ & 2. an active approach \\
\hline $\begin{array}{l}\text { 3. I connect the sound of a new } \\
\text { English word and an image or } \\
\text { picture of the word to help me } \\
\text { remember the word. }\end{array}$ & $\begin{array}{l}\text { 1. a higher and more flexible } \\
\text { ability to new conditions }\end{array}$ \\
\hline $\begin{array}{l}\text { 4. I remember a new English } \\
\text { word by making a mental picture } \\
\text { of a situation in which the word } \\
\text { might be used. }\end{array}$ & $\begin{array}{l}\text { 1. a higher and more flexible } \\
\text { ability to new conditions }\end{array}$ \\
\hline $\begin{array}{l}\text { 13. I use the English words I } \\
\text { know in different ways. }\end{array}$ & 2. an active approach \\
\hline $\begin{array}{l}\text { 14. I start conversations in } \\
\text { English. }\end{array}$ & $\begin{array}{l}\text { 2. an active approach } \\
\text { 8. willingness to use language in } \\
\text { real communication }\end{array}$ \\
\hline $\begin{array}{l}\text { 15. I watch English language TV } \\
\text { shows spoken in English or go to } \\
\text { movies spoken in English. }\end{array}$ & 2. an active approach \\
\hline 16. I read for pleasure in English & $\begin{array}{l}\text { 7. willingness to practice the } \\
\text { language }\end{array}$ \\
\hline $\begin{array}{l}\text { 17. I write notes, messages, } \\
\text { letters, or reports in English. }\end{array}$ & $\begin{array}{l}\text { 7. willingness to practice the } \\
\text { language }\end{array}$ \\
\hline $\begin{array}{l}\text { 18. I first skim an English } \\
\text { passage (read over the passage } \\
\text { quickly) then go back and read } \\
\text { carefully. }\end{array}$ & 4. attention to form \\
\hline $\begin{array}{l}\text { 21. I find the meaning of an } \\
\text { English word by dividing it into } \\
\text { parts that I understand. }\end{array}$ & 5. methodical but flexible \\
\hline $\begin{array}{l}22 . \text { I try not to translate word- } \\
\text { for-word. }\end{array}$ & 9. se \\
\hline
\end{tabular}


23. I make summaries of information that $I$ hear or read in English.

24. To understand unfamiliar English words, I make guesses.

25. When I can't think of a word during a conversation in English I use gestures.

27. I read English without looking up every new word.

28. I try to guess what the other person will say next in English.

29. If I can't think of an English word, I use a word or phrase that means the same thing.

30. I try to find as many ways as I can to use my English

31. I notice my English mistakes and use that information to help me do better.

32. I pay attention when someone is speaking English.

33. I try to find out how to be a better learner of English.

36. I look for opportunities to read as much as possible in English.

37. I have clear goals for improving my English skills.

38. I think about my progress in 10 . internalization learning English.

40. I encourage myself to speak English even when I am afraid of making a mistake.

45. If I do not understand something in English, I ask the other person to slow down or say it again.

49. I ask questions in English
6. one who searches for meaning

1. a higher and more flexible ability to new conditions

2. an active approach

6. one who searches for meaning

1. a higher and more flexible ability to new conditions

1. a higher and more flexible ability to new conditions

7. willingness to practice the language

4. attention to form

4. attention to form

2. an active approach

2. an active approach

5. methodical but flexible

7. willingness to practice the language

4. attention to form 1. an active approach 
Stern's \#1 strategy was used 7 times.

Stern's \#2 strategy was used 7 times.

Stern's \#3 strategy was used 0 time.

Stern's \#4 strategy was used 4 times.

Stern's \#5 strategy was used 2 times.

Stern's \#6 strategy was used 2 times.

Stern's \#7 strategy was used 4 times.

Stern's \#8 strategy was used 1 time.

Stern's \#9 strategy was used 1 time.

Stern's \#10 strategy was used 1 time. 


\title{
CHAPTER IV
}

\author{
RESULTS
}

\section{INTRODUCTION}

This chapter presents the results of the statistical analysis on the number and type of strategies (the dependent variables) used by successful and unsuccessful Malaysian learners of three different ethnic groups, the Malays, the Chinese and the Indians. That is, two types of independent variables, performance and ethnicity were investigated.

In order to answer research questions 1 to 5 , results of the statistical analysis are presented in 4 ways:

1) comparison of strategies used between the successful and unsuccessful learners within each ethnic group (addresses research question 1 and 2 ).

2) comparison of strategies used by ethnic groups of successful learners (addresses research question 3).

3) comparison of strategies used by ethnic groups of unsuccessful learners (addresses research question 4).

4) comparison of strategies used by only the successful learners with those proposed by Stern (addresses research question 5). 
The difference between number (1) and number (2) is in the type of learners. Number (1), for example, is between successful and unsuccessful learners, but number (2) focuses only on successful learners. Number (3) focuses only on unsuccessful learners.

\section{RESEARCH QUESTION \#1}

Within the Malay, Chinese, and Indian ethnic groups, do successful English language learners employ the same kind of learner strategies as unsuccessful learners?

In order to find out if successful learners of all three ethnic groups employed the same kind of strategies, I needed first to find out which strategies had the highest mean score and in which order. This was achieved by an examination of the means. To see the order from the most to the least used strategies of the successful and unsuccessful Malay learners, I rank-ordered the means in a descending order beginning from the highest mean score to the lowest mean score. Reading across Table III for the 5 successful Malay learners, the highest mean score in use was the metacognitive strategies (D), and following in descending order compensation strategies (C), cognitive strategies (B), memory strategies (A), affective strategies (E); and the least used strategies were social strategies (F). 
TABLE III

MANN WHITNEY U TEST: COMPARISON OF STRATEGIES BETWEEN THE SUCCESSFUL AND UNSUCCESSFUL MALAY LEARNERS

\begin{tabular}{clllllll}
\hline & \multicolumn{8}{c}{ STRATEGIES } \\
\hline & & A & B & C & D & E & F \\
\multicolumn{1}{cl}{ S } & N & Mean & Mean & Mean & Mean & Mean & Mean \\
Rank-ordered: & 5 & 2.79 & 2.96 & 3.1 & 3.68 & 2.6 & 2.59 \\
MALAY U & & $(4)$ & $(3)$ & $(2)$ & $(1)$ & $(5)$ & $(6)$ \\
Rank-ordered: & 22 & 2.95 & 3.19 & 3.27 & 3.89 & 2.96 & 3.13 \\
P value & & $(6)$ & $(3)$ & $(2)$ & $(1)$ & $(5)$ & $(4)$ \\
& & .76 & .40 & .58 & .35 & .31 & .13 \\
\hline
\end{tabular}

Mean values of strategies (Note: 5 was the highest; 1 was the lowest)
$S=$ Successful
$\mathrm{B}=$ Cognitive
$E=$ Affective
$\mathrm{U}=$ Unsuccessful
$\mathrm{C}=$ Compensation
$F=$ Social
$\mathrm{A}=$ Memory
$\mathrm{D}=$ Metacognitive

As for the 22 unsuccessful Malay learners, running across the table again from ascending to descending order, the metacognitive strategies (D) produced the highest mean score followed by compensation strategies (C), cognitive strategies (B), social strategies (F), affective strategies (E); and the least used strategies were memory strategies (A).

The strategy that had the highest mean score was metacognitive. Even though this score was not statistically significant, the pattern it represented may have implications for classroom teaching and it was interesting that both successful and unsuccessful Malay learners appeared to give metacognitive 
strategies a high score, suggesting that they tend to use this strategy often.

Taking a look again at Table III, it can also be observed that for successful learners, memory strategies (A) were ranked fourth and social strategies (F) were ranked sixth, whereas for unsuccessful learners, social strategies (F) were ranked fourth and memory strategies (A) were ranked sixth.

In other words, successful Malay learners seemed to use more memory strategies (A) than social strategies (F), whereas unsuccessful Malay learners seemed to use more social strategies (F) than memory strategies (A). These mean scores, however, were rather close together, suggesting that perhaps both memory and social strategies were used only half the time (according to Oxford's SILL inventory ratings). All other strategies were ranked in the same order with means that were also very close together.

Table IV illustrates the strategies used by the Chinese ethnic group. Similarly, I have rank-ordered the strategies used in terms of descending order to see which type of strategies were used the most and least often. In this case the highest mean score for the successful Chinese learners was compensation strategies (C), followed closely by metacognitive strategies (D), cognitive strategies (B), social strategies (F), memory strategies (A) with the lowest mean being the affective strategies (E).

The unsuccessful Chinese learners were also rank-ordered in a descending order starting with compensation strategies (C) followed by metacognitive strategies (D), cognitive strategies (B), memory 
TABLE IV

MANN WHITNEY U TEST: COMPARISON OF STRATEGIES BETWEEN THE SUCCESSFUL AND UNSUCCESSFUL CHINESE LEARNERS

\section{STRATEGIES}

$\begin{array}{llllllll} & & \text { A } & \text { B } & \text { C } & \text { D } & \text { E } & \text { F } \\ & \text { N } & \text { Mean } & \text { Mean } & \text { Mean } & \text { Mean } & \text { Mean } & \text { Mean } \\ & & & & & & & \\ \text { S } & 40 & \mathbf{2 . 5 5} & 3.33 & 3.68 & 3.49 & \mathbf{1 . 7 4} & 2.98 \\ \text { U } & 7 & \mathbf{3 . 0 9} & 3.37 & 3.83 & 3.72 & \mathbf{2 . 4 6} & 2.89 \\ \text { red: } & & (4) & (3) & (1) & (2) & (6) & (5) \\ \text { P value } & & .05 * & .94 & .72 & .33 & .04 * & .94\end{array}$

Bolded figures indicate statistically significant values at $p \leqslant .05$ Mean values of strategies: (Note: 5 was the highest; 1 was the lowest)
$S=$ Successful
$\mathrm{B}=$ Cognitive
$\mathrm{E}=$ Affective

$\mathrm{U}=$ Unsuccessful

$\mathrm{C}=$ Compensation $\mathrm{F}=$ Social

$\mathrm{A}=$ Memory

$\mathrm{D}=$ Metacognitive

strategies (A), social strategies (F); and the least used strategy being affective strategies (E).

It can also be observed from the results that successful Chinese learner's social strategies (F) were rank-ordered fourth, and memory strategies (A) were ranked fifth. As for unsuccessful Chinese learners, memory strategies (A) were ranked fourth and social strategies (F) were ranked fifth. 
It was interesting because the ranking of the mean scores showed a consistent pattern of "inversion", and it also appeared to indicate that successful Chinese learners seemed to use more social strategies than memory strategies as compared to unsuccessful Chinese learners who seemed to use more memory strategies than social strategies. Once again, the mean scores here indicated a rather low score (a range of 2.55 to 3.09) suggesting perhaps that in general Chinese learners used memory and social strategies either less than half the time or half the time only (according to Oxford's SILL ratings). All others (cognitive, compensation, metacognitive and affective) were ranked in the same order with their means being close to each other.

Just as interesting to note even though compensation and metacognitive strategies were not statistically significant, they seemed to be used rather often with average scores ranging from 3.49 to 3.83 , suggesting that Chinese learners were using these two strategies (compensation and metacognitive) more than half the time or almost all the time. Both these strategies were ranked in the same order (i.e: \#1 \& \#2) for successful and unsuccessful Chinese learners.

The strategies used the least by successful and unsuccessful Chinese learners and which turned out to be statistically significant (p .05) were affective strategies with mean scores of 1.74 and 2.46 respectively. The statistically significant mean score would indicate that Chinese learners used affective strategies differently.

Memory strategy also had a statistically significant difference in mean score with successful Chinese at 2.55 and unsuccessful 
Chinese at 3.09, indicating likewise that the use of memory strategies are used differently. Even though the mean scores of memory strategies were slightly higher than affective strategies, according to Oxford's rating scale, it would indicate that the use of memory and affective strategies was not reported often.

In Table $\mathrm{V}$, the results were similarly ordered in descending order from the highest mean score. For the 18 successful Indian learners, compensation strategies (C) were ranked the highest, followed closely by metacognitive strategies (D), cognitive strategies (B), social strategies (B), memory strategies (A): and the least used strategies were the affective strategies (E).

As for the 6 unsuccessful Indian learners, the highest ranked mean score was compensation strategies (C), followed by metacognitive strategies (D), social strategies (F), cognitive strategies (B), memory strategies (A): and the least used strategies were affective strategies (E).

It can also be observed from Table $V$ that for the 18 successful Indian learners, cognitive strategies (B) were ranked third and social strategies (F) were ranked fourth. Conversely, it was interesting to note that for the unsuccessful learners, social strategies were rankedthird and cognitive strategies were ranked fourth. 
TABLE $\mathrm{V}$

MANN WHITNEY U TEST: COMPARISON OF STRATEGIES BETWEEN THE SUCCESSFUL AND UNSUCCESSFUL INDIAN LEARNERS

\section{STRATEGIES}

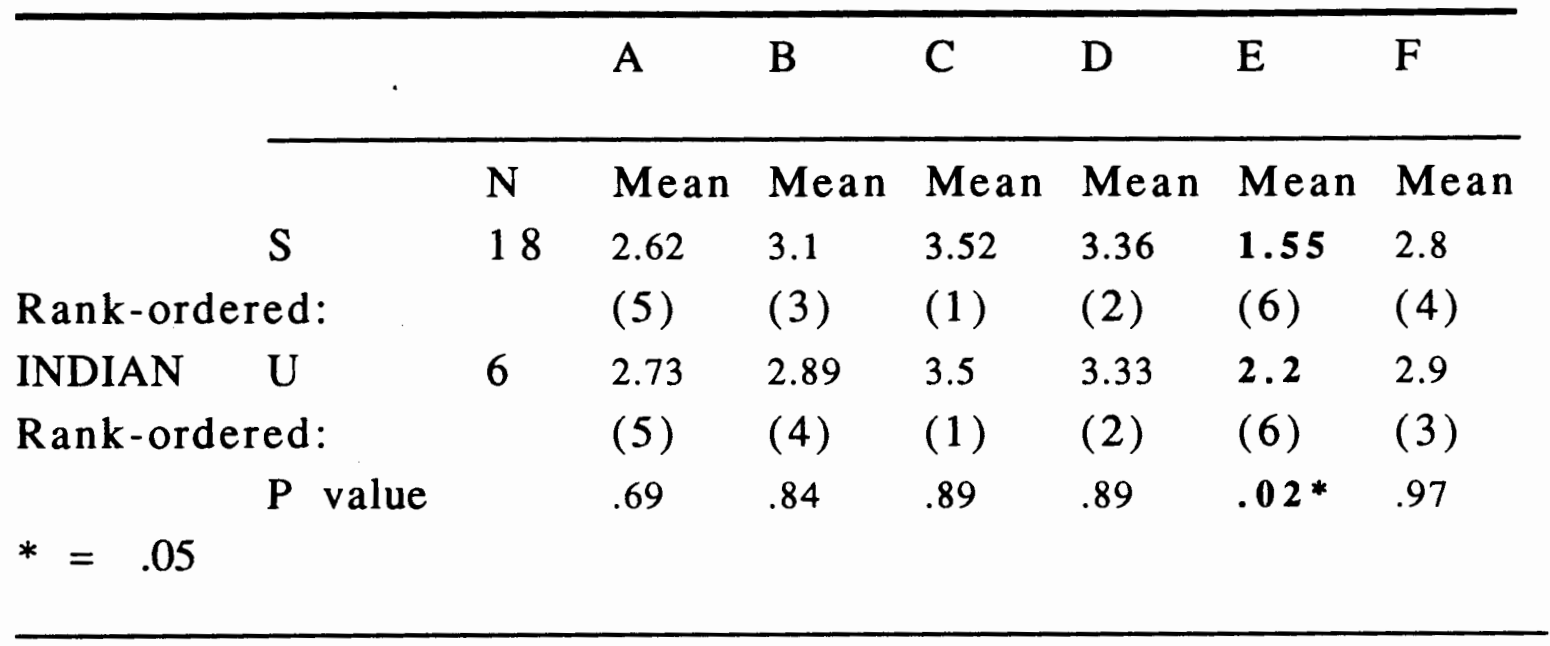

Bolded figures indicate statistically significant values at $\mathrm{p} \leq .05$.

Mean values of strategies: (Note: 5 was the highest; 1 was the lowest)
$S=$ Successful
$\mathbf{B}=$ Cognitive
$\mathrm{E}=$ Affective
$U=$ Unsuccessful
$\mathrm{C}=$ Compensation
$F=$ Social
$\mathrm{A}=$ Memory
$\mathrm{D}=$ Metacognitive

Even though the results for both the above mentioned strategies were not statistically significant, the inversion of the ranking order produced a pattern that was worth taking note of.

The results above would appear to indicate that successful Indian learners seemed to use more cognitive strategies than social strategies, whereas unsuccessful learners seemed to use more social strategies than cognitive strategies. All other strategies were ranked in the same order with means that were close. 


\section{RESEARCH QUESTION \#2}

Within the Malay, Chinese, and Indian ethnic groups, do successful English language learners have different mean scores on the Strategy Inventory for Language Learning (SILL) than unsuccessful learners?

Tables III, IV and $\mathrm{V}$ also address research question \#2, Table III shows strategies between the 5 successful and 22 unsuccessful Malay learners. Since there were no mean score differences that were significant, it would be difficult to say if successful Malay learners used more or less strategies than unsuccessful Malay learners.

Table IV shows the strategies used by the 40 successful and 7 unsuccessful Chinese learners. Since the difference in mean scores for memory and affective is statistically significant, and the mean score for the successful Chinese in memory strategy is 2.55 , as compared to the unsuccessful Chinese learners with a mean score of 3.09 , it can be said that successful Chinese learners used less memory strategies than unsuccessful Chinese learners. Similarly, for affective strategies, the mean value for successful learners was less than the mean value for unsuccessful learners at 1.74 and 2.46 respectively (refer to Table IV).

Table $V$ shows the mean scores of the 18 successful and 6 unsuccessful Indian learners. The statistically significant difference 
in mean score for affective strategy would indicate that successful Indian learners used less of this group of strategies than unsuccessful learners.

It was noticeable that there was a statistically significant difference in the use of memory strategies for the successful and unsuccessful Chinese but not for the successful and unsuccessful Indians. Also, the other noticeable aspect of the results was that both the successful and unsuccessful Chinese and Indian learners had a statistically significant difference in use of affective strategies. The Malay group, on the other hand, had no statistically significant difference in the use of any of its strategy groups.

Table VI shows the total number of students in each ethnic group and the mean number of strategies used by just the successful Malay, Chinese and Indian learners. Overall, there were no statistically significant differences among the three successful ethnic groups with respect to the use of strategies except affective strategies (E).

\section{RESEARCH QUESTION \#3}

Within successful learner groups, do the Malay, Chinese, and Indian ethnic groups have significantly different mean scores on the Strategy Inventory for Language Learning (SILL)?

Table VI shows the mean scores of successful Malay learners for affective strategies at 2.6, the Chinese at 1.74 and the Indians at 2.2 (see Table VI). The results do not say whether or not a certain 
group uses more or less of affective strategy. For example, it could also be said that perhaps the Chinese used less than the Malays and Indians, who did not differ very much between each other. It nevertheless demonstrates that the use of affective strategies was not the same; that they used it differently. Followup T-tests would reveal which of the three groups was different.

\section{RESEARCH QUESTION \#4}

Within unsuccessful learner groups, do the Malay, Chinese, and Indian ethnic groups have significantly different mean scores on the Strategy Inventory for Language Learning (SILL)?

The results in Table VII shows the total number of unsuccessful students in each ethnic group and the mean number of strategies used by just the unsuccessful learners. There was no statistically significant difference in the use of any strategy groups except in the affective strategies (E) group. The affective strategy was the only one that had a statistically significant difference in the mean score.

The data in Table VII parallel those found for successful learners in Table VI. If Table VI and Table VII were compared it could be observed that for both successful and unsuccessful learners of all major ethnic groups, metacognitive and compensation strategies had very high mean scores (range of 3.1 to 3.89 ). This 
TABLE VI

KRUSKAL-WALLIS COMPARISON OF STRATEGIES BY ETHNIC GROUPS OF SUCCESSFUL LEARNERS

\section{SUCCESSFUL LEARNERS' STRATEGIES}

\begin{tabular}{|c|c|c|c|c|c|c|c|c|}
\hline & & A & & B & $\mathrm{C}$ & D & $E$ & $\mathrm{~F}$ \\
\hline & $\mathbf{N}$ & Mean & & Mean & Mean & Mean & Mean & Mean \\
\hline MALAY & 5 & 2.79 & & 2.96 & 3.1 & 3.68 & 2.6 & 2.59 \\
\hline CHINESE & 40 & 2.55 & & 3.33 & 3.68 & 3.49 & 1.74 & 2.98 \\
\hline INDIAN & 18 & 2.73 & & 2.89 & 3.5 & 3.33 & 2.2 & 2.9 \\
\hline P Value $=$ & & & .66 & .12 & .17 & .42 & $.01 *$ & .36 \\
\hline TOTAL $\mathbf{N}=$ & 63 & & $*=$ & .05 & & & & \\
\hline
\end{tabular}

Bolded figure indicates significant value at $\mathrm{p} \leqslant .05$.

Mean value of strategies: (Note: 5 was the highest; 1 was the lowest)
$S=$ Successful
$\mathrm{B}=$ Cognitive
$\mathrm{E}=$ Affective
$\mathrm{U}=$ Unsuccessful
$\mathrm{C}=$ Compensation
$F=$ Social
$\mathrm{A}=$ Memory
$\mathrm{D}=$ Metacognitive

would seem to indicate that compensation strategies and metacognitive strategies appeared to be used very often.

At first it would appear that all three ethnic groups gave metacognitive strategies the highest score, but on closer inspection, the Chinese and Indian unsuccessful learners appeared to rate compensation strategies slightly higher than metacognitive strategies. As for Malay learners, they rated compensation as the next highest score. 
However, it must again be noted that since both metacognitive and compensation strategies had no statistically significant differences in mean scores, it would be difficult to draw any solid conclusions from this. Nevertheless, it was interesting that there was a definite pattern that had emerged, and it would appear that metacognitive and compensation strategies seemed to be used often for both type of learners.

Also, for both the successful and unsuccessful learners, it was with respect to affective strategies that the difference in mean scores was statistically significant. This would indicate that successful and unsuccessful learners of different ethnic groups used affective strategies differently.

Table VII shows the mean scores of the unsuccessful Malay learners for affective strategy at 2.96, the Chinese at 2.46 and the Indians at 2.2. It is important to note once more that even though the use of affective strategies was not the same, it did not necessarily imply that unsuccessful Malay learners used it more than unsuccessful Chinese or Indian learners.

\section{RESEARCH QUESTION \#5}

Do the successful learners employ most of the strategies proposed by Stern? 
TABLE VII

KRUSKAL-WALLIS COMPARISON OF STRATEGIES USED BY ETHNIC GROUPS OF UNSUCCESSFUL LEARNERS

\section{UNSUCCESSFUL LEARNERS' STRATEGIES}

$\begin{array}{llllll}\text { A } & \text { B } & \text { C } & \text { D } & \text { E } & \text { F }\end{array}$

$\begin{array}{llllllll} & \mathrm{N} & \text { Mean } & \text { Mean } & \text { Mean } & \text { Mean } & \text { Mean } & \text { Mean } \\ \text { MALAY } & 22 & 2.95 & 3.19 & 3.27 & 3.89 & 2.96 & 3.13 \\ \text { CHINESE } & 7 & 3.09 & 3.37 & 3.83 & 3.72 & 2.46 & 2.89 \\ \text { INDIAN } & 6 & 2.73 & 2.89 & 3.5 & 3.33 & 2.2 & 2.9 \\ \text { P Value }= & & .61 & .72 & .17 & .07 & .04^{*} & .72 \\ \text { Total N }= & 35 & *=\mathrm{p} & .05 & & & \end{array}$

Bolded figures indicate statistically significant values at $\mathrm{p}: \leqslant .05$.

Mean value of strategies: (Note: 5 was the highest; 1 was the lowest)
$S=$ Successful
$\mathrm{B}=$ Cognitive
$\mathrm{E}=$ Affective
$\mathrm{U}=$ Unsuccessful
$\mathrm{C}=$ Compensation
$F=$ Social
$\mathrm{A}=$ Memory
$\mathrm{D}=$ Metacognitive

From the results, it was calculated that 27 of 50 Oxford's (1990) strategies were used the most often. These strategies were then listed and compared to Stern's 10 proposed strategies of what makes a good language learner.

From Table II, it can be seen that almost all of Stern's strategies were employed at least one time except for Stern's third strategy, "an outgoing, open and tolerant approach". For example, Stern's first strategy was used at least six times; the second strategy, seven times; the third strategy, none; the fourth strategy, three 
times; the fifth strategy, two times; the sixth strategy, two times; the seventh strategy, four times; the eighth strategy, one time; ninth strategy, one time and the tenth strategy, one time.

It would appear that Stern's first (a higher and more flexible ability to new conditions) and second (an active approach) strategies were employed the most often. The least used strategy was Stern's eighth (willingness to use language in real communication), ninth (self-monitoring) and tenth (internalization) strategies. They were each used only once (refer to Table II).

Table VIII shows the statistically significant results found for successful and unsuccessful Chinese, successful and unsuccessful Indians as well as for successful and unsuccessful learners of all three ethnic groups (see Table VIII). 
TABLE VIII

STATISTICALLY SIGNIFICANT VALUES OF ALL ETHNIC GROUPS

STRATEGIES

\begin{tabular}{llllll}
\hline & $B$ & $C$ & $D$ & $E$ & $F$ \\
\hline
\end{tabular}

MS

MU

\begin{tabular}{lll}
$\mathrm{CS}$ & $*$ & $*$ \\
\hline $\mathrm{CU}$ & $*$ & $*$
\end{tabular}

IS

*

$\underline{\mathrm{IU}}$

$\underline{s}$

$\underline{\mathrm{U}}$

* indicates statistically significant values at $\mathrm{p} \leqslant .05$.

MS = Successful Malays

$A=$ Memory strategies

MU = Unsuccessful Malays

$\mathrm{B}=$ Cognitive strategies

$\mathrm{CS}=$ Successful Chinese

$\mathrm{C}=$ Compensation strategies

$\mathrm{CU}=$ Unsuccessful Chinese

$\mathrm{D}=$ Metacognitive strategies

IS = Successful Indians

$E=$ Affective strategies

$\mathrm{IU}=$ Unsuccessful Indians

$F=$ Social strategies 


\section{CHAPTER V}

\section{DISCUSSION}

\section{INTRODUCTION}

The aim of this study was to discover the number and type of learner strategies that Malaysian learners (Malays, Chinese and Indians) used while studying a second language, in this case, English. My study used Stern's list of strategies that good language learners used as a basis for comparison of strategies used by Malaysian learners. In order to carry out this study, I used Oxford's Strategy Inventory for Language Learning (SILL). A statistical analysis revealed some significant differences in the strategies used by the three ethnic groups, the Malays, the Chinese and the Indians. This chapter will discuss in further detail the results, analysis, limitations of the present study and recommendations for future studies.

It is not possible to draw any solid conclusions about the general population from the apparent differences in strategies use of Malaysian learners, since many of the mean scores were not statistically significant. Furthermore, since the subjects are of a particular school the characteristics of strategies used by Malaysian learners may be characteristic for only those particular subjects of 
that school. The results found here are probably generalizable to this particular school and not others. Also, a possible reason for the few statistically significant scores may lie in the unequal and low number of subjects from various ethnic groups in the sample.

\section{RESEARCH QUESTIONS}

1. Within the Malay, Chinese, and Indian ethnic groups, do successful English language learners employ the same kind of learner strategies as unsuccessful learners?

Overall, there were no statistically significant differences in mean scores of the successful and unsuccessful Malay learners' strategies. This would seem to indicate that there were no differences in the use of any of the strategy groups between successful and unsucessful Malay learners (see Table III).

Nevertheless, a pattern of inversion emerged that proved to be interesting. It would appear that successful Malay learners use more memory strategies than social strategies, whereas unsuccessful Malay learners seemed to use more social strategies than memory strategies.

Although there were only 27 Malay learners in the sample, and thus generalization for the whole population cannot be made, the results are a good reflection of that particular school sampled. One possibility for the pattern of inversion may be that Malay learners were already located in classes that had been tracked. The 
successful Malay learners who came from a higher achieving class knew they were successful learners, and similarly unsuccessful Malay learners who came from a lower achieving class knew they were not particularly successful learners.

The knowledge that they were in a higher achieving class may have encouraged or motivated them to do more than the bare minimum of work. The successful Malay learners seemed to favor using memory strategies that required more conscious individual planning such as creating mental linkages, applying images and sounds, reviewing and employing action.

Such conscious individual planning strategies may have been promoted by the highly-structured method of teaching in class which may have had an effect on the strategies that successful Malay learners used. For example, in class, there was a lot of reviewing of lessons and repetition of words. Such methods of teaching may have facilitated the use of "reviewing and employing action" (one of Oxford's memory strategies) for successful Malay learners.

The school situation provided an environment that facilitated the use of social strategies. Social strategies included asking questions, cooperating with others and empathizing with others. These were the kinds of strategies that Malay learners were required to do anyway, given the multi-ethnic environment of that particular school. The unsuccessful Malay learners were forced to speak English and interact with students of other ethnic backgrounds on a daily basis, and since they were high school students, they learned to cooperate with their peers or cooperate with proficient users of the 
new language. The unsuccessful learners may tend to use social strategies to just get by conversationally with their peers.

The Muslim religion may also be a factor in explaining successful Malay learners use of memory strategies. In their religion, they have to recite from the Quran daily, which may have facilitated the practice of listening to and distinguishing sounds. Successful Malay learners may then have learned to link sounds with new English words that they are trying to learn. As such, memory strategies that include strategies such as "applying images and sounds" seem to be a transference applied by successful learners from previously learned experience. Unsuccessful Malays, for lack of interest perhaps in learning the language due to their belief that they are low achievers may not have learned to incorporate what they already knew from their religion, to assist them in learning English.

As for successful and unsuccessful Chinese learners, there were no statistically significant difference in mean scores except for memory and affective strategies. Interestingly unsuccessful Chinese learners reported using more memory and affective strategies than successful Chinese learners (see Table IV).

Even though there was a difference in the use of both these strategies, upon closer inspection it can be seen that in general, both these strategies were one of the least ranked strategies. Memory strategies were ranked fourth and fifth, and affective strategies especially were ranked last. This would indicate that memory and 
affective strategies were not used very often by either successful or unsuccessful Chinese learners.

Memorization and recitation have had their roots in traditional Chineses ideas about education. These strategies are believed to be the best form of learning in Chinese schools, and this belief prevails for many Chinese today (Huang, 1987). This method of learning still influences the way Chinese learn in West Malaysia today, and it is hardly surprising to find its traces in English schools as well.

Memorized chunks of words or phrases may serve to help get conversation going and to build up confidence in speaking. It is possible that unsuccessful Chinese learners rely more heavily on memory strategies than successful Chinese learners to help them build up confidence in themselves or to start conversations in school where English would be most needed. Successful Chinese learners are likely to be more confident than unsuccessful Chinese learners since their language proficiency is higher, and thus rely less on memorization.

The use of affective strategies seems to be different between successful and unsuccessful Chinese learners. It is also the least used strategies according to Oxford's rating scale. This means that affective strategies are in general hardly ever used. Since both successful and unsuccessful Chinese learners hardly ever use affective strategies, the difference in use seems hardly meaningful, and it perhaps points to one of degree only.

The general lack of use of affective strategies by both groups may stem from the language situation at home and in school. Since 
they speak the most English at home and in school, it would seem reasonable to assume that they are not tense or nervous about their language proficiency. As such, there is no need to relax or write down their feelings in a language diary (part of the strategies listed in the SILL).

The slight difference in the use of affective strategies may indicate that unsuccessful Chinese learners may be slightly more tense or nervous than successful Chinese learners but not by a very large degree.

As with Malay learners, Chinese learners also produced a pattern of inversion. Memory and social strategies were found to be closely inverted. Memory strategies for successful Chinese were ranked fifth, whereas for unsuccessful Chinese they were ranked fourth. Similarly, memory strategies for successful Chinese were ranked fourth, whereas for unsuccessful Chinese they were ranked fifth.

It would be difficult to draw any conclusions about the use of social strategies of Chinese learners since the results were not statistically significant, the difference in mean scores was very small, and they were also some of the least used strategies according to Oxford's scale. This would similarly apply to the use of memory strategies.

Nevertheless the consistent pattern of inversion is important since it draws attention to the use of strategies. It may also indicate that when it comes to strategies that are not used very often, not 
only are the differences in use minimal, but also certain strategies are not used in the same order as the rest of the general strategies.

At this point, I emphasize once again that any solid conclusions about the use of strategies especially in inversion cases cannot be drawn. However, conjectures as to why the inversion takes place seem reasonable in light of the findings that demonstrates a consistent pattern.

As for both successful and unsuccessful Indian learners there was no statistical differences in mean scores in most of the strategy groups save affective strategies. These were also the least used strategy of all strategy groups. The mean score indicated that unsuccessful Indian learners used slightly more affective strategies than successful learners.

A possible reason could be in the language situation at home. Successful Indian speakers clearly spoke more English than unsuccessful Indian learners at home. Successful Indian learners who spoke just English without an accompanying language at home accounted for $72 \%$ of the total successful Indian learners. Unsuccessful Indian learners who spoke just English at home accounted for only $16.6 \%$ of the total unsuccessful Indian learners. Successful Indian learners in comparison with unsuccessful learners clearly seemed to speak more English at home. Because the successful Indian learners speak English at home, they may be more likely to be less nervous and more confident about their language proficiency. 
It has been my experience and observation that affective strategies which include strategies such as lowering your anxiety, encouraging yourself and taking your emotional temperature are likely strategies that unsuccessful Indian learners with less confidence or anxiety are more apt to use than successful Indian learners. Successful Indian learners who spoke more English at home may have a higher proficiency level in spoken English than unsuccessful Indian learners which may account for the greater anxiety perhaps experienced by unsuccessful Indian learners. As such the unsuccessful Indian learners may indulge in affective strategies to a greater extent to reduce their anxiety.

As with Malay and Chinese learners, there was also a consistent pattern of inversion that emerged for Indian learners The pattern seemed to indicate that successful Indian learners use more cognitive strategies than social strategies, whereas unsuccessful learners use more social strategies.

Cognitive strategies include practicing, receiving and sending messages, analyzing and reasoning, and creating structure for input and output. Social strategies have already been described while discuissing successful and unsuccessful Malay learners.

A possible reason that successful Indian learners appeared to use slightly more cognitive strategies than social strategies may again be due to the amount of English spoken at home.

Cognitive strategies are indicated by such activities as trying to talk like native speakers, starting conversations in English, watching English language TV shows spoken or going to movies spoken in 
English. These are strategies that successful learners would seem to use more than unsuccessful learners since they spoke more English at home, and are thus perhaps more comfortable in using such strategies.

It would also explain why successful Indian learners do not use social strategies as much as unsuccessful Indian learners. If they are successful and sufficiently fluent in English, there is less of a need to use social strategies such as, "I ask for help from English speakers", or "I ask English speakers to correct me when I talk".

2. Within the Malay, Chinese, and Indian ethnic groups, do successful English language learners have significantly different mean scores on the Strategy Inventory for Language Learning (SILL) than unsuccessful learners?

As to the differences in mean scores of strategies used, it would appear that the differences in mean scores between successful and unsuccessful learners of all three ethnic groups did not differ very much in all strategy groups. The slight differences in mean scores may indicate that the number of strategies used was not very different between the successful and unsuccessful groups. If there were any differences in use of strategies (as indicated by the statistically significant values), the difference seems to be small.

For successful and unsuccessful Malay learners, metacognitive strategies had the highest mean score with 3.68 and 3.89 respectively, with a slight difference in mean scores. This indicated a 
high use of metacognitive strategies for both successful and unsuccessful Malay learners.

Similarly, successful and unsuccessful Chinese learners also had high mean scores for metacognitive strategies (3.49 and 3.72 respectively). In addition, compensation strategies were also scored high with mean scores of 3.68 and 3.83 for successful and unsuccessful Chinese learners respectively. The difference in mean scores was also very small between use of metacognitive and compensation strategies.

As for successful and unsuccessful Indian learners, compensation and metacognitive strategies had high mean scores and with only very slight differences between the use of strategies. For compensation strategies, successful and unsuccessful Indian learners had mean scores of 3.52 and 3.5 respectively; and for metacognitive strategies, the mean scores were 3.36 and 3.83 respectively.

In this case, it was difficult to compare just successful and unsuccessful learners of all three ethnic groups for several reasons. First of all, most of the mean scores were not statistically significant, and second there were hardly any substantial differences in mean scores between successful and unsuccessful learners. As such, I looked at the most outstanding/conspicous factors that learners had in common, which was in their use of metacognitive and compensation strategies.

Metacognitive strategies could be described as centering one's learning, arranging and planning one's learning, and evaluating one's 
learning, whereas compensation strategies included guessing intelligently and overcoming limitations in speaking and writing.

A possible reason for the high selection of metacognitive strategies by both successful and unsuccessful Malay, Chinese and Indian learners could be due to the political situation and urban environment in West Malaysia.

The promotion of English as an important language by the Malaysian government in recent years may have had an indirect influence on the strategies that Malaysian learners use. The promotion of English at a national level, may have directed Malaysian learners' attention to the language and made people reflect harder on their language abilities.

In an urban environment in West Malaysia, there are many different ethnic groups living and working together. Big businesses that are mainly concentrated in urban cities frequently require that an employee be able to speak English as well as B.M. Malaysian learners who are exposed to such an environment and can clearly see the practical benefits of learning English begin to take the language more seriously, and become more motivated in learning the language.

The change in focus and increased motivation towards the language may have encouraged them, for example, to evaluate their learning by applying such strategies as self-monitoring or selfevaluating. In addition, in a multi-ethnic mix in school and in the cities, where English is spoken more often, the environment is 
conducive in allowing Malaysian learners to seek practice opportunities.

The results above support the hypothesis formulated by numerous researchers that successful and unsuccessful learners use about the same number of strategies (Vann \& Abraham, 1990). However, it would contradict other findings that more successful learners use different kinds of strategies than unsuccessful learners.

In summary, the kinds of strategies that successful and unsuccessful Malay, Chinese and Indian learners used in general did not appear to be so different. The differences in mean scores of strategies that successful and unsuccessful Malay, Chinese and Indian learners used were, on the whole, small.

Furthermore, in my study, any conclusions about whether the learners used the strategies appropriately or not cannot be assumed since my survey did not include the different tasks at hand to certain strategies. It sought to find out in general the type and number of strategies used while learning a second language, but did not investigate the specific task at hand (reading, writing, speaking and listening).

Nevertheless, the results here prove interesting because they show that in West Malaysia, the learners are perhaps using certain strategies differently or in some cases not at all.

The low mean scores in some of the strategy groups in my results fall into the "never" or "almost never" use strategies according to Oxford's inventory. This is an important fact to note since it may be a signal that something else is happening here. Malaysian 
learners in general may be using some other form of strategies not listed in Oxford's SILL or strategies normally used by Malaysians are not applicable to these learners. Other factors such as social factors may also have accounted for the students lack of use of certain strategies.

3. Within successful learner groups, do the Malay, Chinese, and Indian ethnic groups have significantly different mean scores on the Strategy Inventory for Language Learning (SILL)?

There were no statistically significant differences in terms of differences in mean scores for the successful ethnic groups, except for affective strategies (E). Under the category "affective strategies", successful Malays had a higher mean score (2.6) than the other two ethnic groups (1.74 and 2.2). The successful Indians had the second highest mean score for affective strategies (2.2), and the successful Chinese had the lowest mean score for affective strategies (1.74) among the three groups (see Table VI).

These results could be interpreted in several ways. First, it could be interpreted that successful Malay learners' use of affective strategies is different from that of successful Chinese and Indian learners. It could also be argued that the successful Chinese' use of affective strategies seemed to be very low when compared to the rest. And finally, it could be said that since the Indians' use of affective strategies seemed closer in mean score to the successful 
Chinese, they seemed to be using them with the same amount of frequency as successful Chinese learners.

According to Oxford's inventory and the way she rated her scores, it could be argued that successful Malay learners' use of affective strategies was more than successful Chinese or Indian learners' since the Malay learners' mean score was closer to the mean score of Oxford's 3.0 indicating, "somewhat true of me". The successful Chinese and Indians' use of affective strategies would be considered closer together than successful Malay learners, since their mean scores were closer to Oxford's scale of 2.0, indicating "usually not true of me".

In following Oxford's scale, it would be then reasonable to assume that it was successful Malay learners who used affective strategies differently than successful Chinese and Indian learners. They seemed to use affective strategies slightly more than the other two ethnic groups.

4. Within unsuccessful learner groups, do the Malay, Chinese, and Indian ethnic groups have significantly different mean scores on the Strategy Inventory for Language Learning (SILL)?

Similarly, the results in this study revealed that like successful learners, unsuccessful learners had a statistically significant difference in mean score use for affective strategies. This would again indicate that use of affective strategies were used differently among the three ethnic groups. 
The unsuccessful Malay learners had a mean score of 2.96 slightly higher than unsuccessful Chinese (2.46) and Indian learners (2.2.) (see Table VII). Again, according to Oxford's scale, the results indicated that unsuccessful Malay learners seemed to use affective strategies slightly more than unsuccessful Chinese and Indian learners.

A possible reason why successful and unsuccessful Malay learners seem to be using slightly more affective strategies could be in the language environment at home. Among all three ethnic groups, Malay learners used less English at home than Chinese and Indian learners. None of the Malay learners, for example, spoke just English at home, and about $37 \%$ spoke both Malay and English at home. The Chinese and Indian learners on the other hand appeared to speak more English at home. Approximately $19.1 \%$ of Chinese learners spoke only English at home, and another $65.9 \%$ spoke English and Chinese. The Indian learners seemed to speak the most English at home, with $58.3 \%$ speaking just English at home and another $25 \%$ speaking Indian and English at home (see Figure 5, 6, \& 7).

The lack of English use at home for Malays in general may have caused them some anxiety about their language proficiency at school. Since the other two ethnic groups tended to speak more English at home, it would be safe to assume that they also did the same with their peers at school. The more English being used among Chinese and Indian learners especially at this school may have caused Malay learners who come into contact with these two ethnic groups to use 
certain affective strategies whose activities include strategies such as, "If I do not understand something in English, I ask the other person to slow down or say it again" or "I ask English speakers to correct me when I talk" or "I ask for help from English speakers". It would also be reasonable to assume that such strategies would be asked more often of the Chinese and Indian learners by Malay learners rather than the other way around since Malay learners were not inclined to speak English at home nor at school.

An important factor to note as well is in the use of, "English speakers" in the statements mentioned above. "English speakers" probably meant native speakers. In West Malaysia, since most people are brought up bilingually, it is sometimes difficult to say if they are native speakers of English. The subjects in this study probably interpreted "English speakers" to mean anyone who speaks English more than half the time and this would then refer more to Chinese and Indian learners.

Overall, some interesting facts have surfaced from an analysis of successful and unsuccessful learners. First, there appeared to be very little differences in mean scores for all major strategies. Second, it was only the use of affective strategies that had a significant difference in mean scores. And third, it always appeared that Malays used affective strategies more than Chinese or Indians.

In summary, the statistically significant results indicated that use of affective strategies were not the same. In order to find out in fuller detail exactly how differently affective strategies were used, T-tests would have to be performed. 
5. Do the successful learners employ most of the strategies proposed by Stern?

Successful learners employed most of the strategies proposed by Stern. Nine out of the ten strategies listed by Stern that represented good learner strategies, were used by the successful learners. The strategy that was not used at all was the third strategy that stated good language learners should have "an outgoing, open and tolerant approach". Stern's strategies that were employed the most were one, two, four and seven. The first strategy states, "a higher and more flexible ability to adjust to new conditions"; the second strategy: ' an active approach"; the fourth strategy: "attention to form"; and the seventh strategy, "willingness to practice the language" (refer to Table II).

Thus, the results in this study would seem to support Stern's hypothesis that good language learners use his proposed strategies, even though his proposed strategies were not used in equal amounts. There was definitely a preference for some of Stern's strategies and not others.

The first strategy (a higher and more flexible ability to adjust to new conditions) was used more often perhaps because Malaysians being of such diverse cultures need to be more flexible in their approach in dealing with different situations and people. Being of such diverse cultures, there is a potential for cultural misunderstandings to occur. In order to maintain a harmonious 
order, Malaysian people need to learn how to live side-by-side with each other. Any misunderstandings that occur needed to be dealt with in an appropriate and immediate manner.

However, the maintenance of a harmonious order may not be so easy since each ethnic group may handle the problem in a different way. Nevertheless, when confronted with a task or problem, Malaysians try to seek different ways in solving the problem and are prepared to change their ways if necessary. This ability to change and adapt to new problems may be a reason for their flexiblility when adjusting to new conditions.

The second strategy, (active approach) was one of the most frequently used. By Stern's definition, an active approach meant that good language learners "adopt an attitude of personal responsibility for their own learning" and that "they select the learning objectives for themselves and take deliberate steps to involve themselves in the language" (Stern, p. 301, 1974). In the Malaysian culture, people are taught from youth to be responsible and to involve themselves in whatever they may be doing. The way they involve themselves, however, may be different than in other cultures. Malaysians may not be as outgoing or as assertive as Westerners, but their involvement may be in terms of being quiet and receptive. In class, for example, just because they are taught in general to be more quiet, polite and passive, does not necessarily mean they are not receptive to what is being taught. In fact, Stern (1975) makes it a point to say that good learners at certain stages deliberately adopt a 
receptive stance. This does not, however, mean they are passive or resistant to the demands of the lessons or tasks.

The next most popular strategy used was "attention to form". Of all the strategies listed, this would certainly be the one most often used by Malaysians. In school, Malaysians have been taught all their life to be rule-oriented and to pay attention to details. In class, the methodology used by teachers is mainly a rule-governed, attention to detail form of teaching. Thus, it does not seem surprising that "attention to form" dominated "attention to meaning" for students when learning English. They are able to single-out what is and what is not relevant, and to pay extra attention to detailed forms in English. As Stern (1974) puts it, the good language learner must be able "to isolate those linguistic features which will give him maximum intelligibility" (p. 304).

Another popular strategy was Stern's seventh strategy stating a willingness by the subjects to practice the language. Most Malaysians are willing to practice the language in their environment. In urban cities, most Malaysians are required to have some knowledge of both English and B.M. It is in the cities with the most ethnic mix that opportunities to converse either in English or B.M. are the greatest. This is likewise the situation in school, where English is also spoken rather frequently. Furthermore, it is also in the cities that availability of English books is abundant. Malaysians have a greater choice in selections of texts and may be encouraged to read or write more in English. As such, the social and language conditions 
in a city enable Malaysians to practice their English more than they normally would if they were living in a rural area.

In the United States, recent findings seem to point to the fact that good language learners use more and better learning strategies than do poor language learners (Oxford, 1989). the Malaysians in my study, on the other hand, seem to use almost the same number and the same kind of strategies. In types of strategies, it would appear that only memory and affective strategies were used differently. All three ethnic groups used compensation and metacognitive the most. The finding for compensation and metacognitive strategies was consistent for all three ethnic groups. One would have actually expected them to use very different types and numbers of strategies considering their different backgrounds and their different levels of performances in a multi-ethnic environment.

The differences in findings among different countries may reveal that findings in one country are greatly linked to learners' cultural backgrounds, and thus one should be cautious in trying to generalize results to other countries. As Politzer and McGroarty (1985) aptly put it, "our conceptions of good language learning strategies might be ethnocentrically biased" (p. 123). They also believe that the answer might lie in what we perceive as the goal of language learning, whether it be for social communication, or for instrumental reasons or for other reasons. And if language learning is for other purposes, other strategies may be labelled as "good".

Thus, I realized that even for my own study, Oxford's SILL inventory probably caters more to the Western concepts of learning 
strategies. The Western concept is more rooted in an open, active approach of learning without a rigid structure, whereas the Eastern concept is more rooted in a close, passive and structured way of learning. Hence, for example, a strategy that Malaysians may use more often than those in the West is looking up words in a dictionary, as opposed to asking a native speaker for clarification, or memorizing English rules and words for the form instead of its meaning. The strategies listed in Oxford's inventory are more Western-oriented in that these are probably strategies used more often by Western learners than by Eastern learners. Rote memorization, for example, is not listed as one of the possible strategies that learners use, but this is the one strategy that is most often used by Malaysians since we are taught to do that in school.

\section{LIMITATIONS OF THE STUDY}

In this study, there have been some limitations. The study first of all was carried out in a different country, in a location from the researcher, which thus made it more difficult to supervise. Even though I had given specific instructions to the teachers who actually carried out the study, I cannot be $100 \%$ sure that it was carried out according to the instructions. That is, since I did not personally carry out the survey, there could have been other factors that affected the results which I am unaware of.

Also, the numbers of Malay, Chinese and Indian learners were not as equal nor as many as I had first hoped. There were, for 
example, a total of 5 successful Malays, 40 successful Chinese and 18 successful Indians. As for the unsuccessful Malays, there were a total of 22 unsuccessful Malays, 7 unsuccessful Chinese, 6 unsuccessful Indians. This unequal number could have perhaps affected the resultant data, and have been a possible reason why there were not as many statistically significant differences between the mean scores.

Third, as was mentioned previously, a class of high achievers and low achievers wer chosen. Because they were unsuccessful in both classes, it is difficult to tell how prior academic achievement affected language learning. Hence, some of the unsuccessful learners may actually come from the high achieving class and vice versa.

Fourth, it would have helped my study more if a question about the frequency of languages spoken at home was included in the background questionnaire. Even though the type of language(s) spoken by each successful and unsuccessful learner of each ethnic group was given by the students in the background questionnaire, it was not possible to figure out exactly how much each language or dialect was actually used at home.

Fifth, there could also have been more revealing results if Rebecca Oxford's SILL was more Eastern-based than Western-based as mentioned earlier. Some of Oxford's (1990) strategies for language learning which are Western-based may not be wholly applicable to Malaysian students. For example, the use of rhymes is a strategy that is Western-oriented, and such a strategy is not used by Malaysian teachers nor promoted among students. Of course, this 
does not rule out the possibility that learners have developed such strategies as mentioned above on their own, but since creativity is discouraged, the possibility is small.

Also, rote memorization is one of the most common learning strategies. However, in the SILL there are no direct questions dealing with it. These are reasons that may have become problematic when using Oxford's direct form in a multi-ethnic setting. Nevertheless, on the whole, most of her strategies are applicable to learners from different sociolinguistic contexts and they make up the most comprehensive and detailed inventory thus far designed in the language learning strategy field.

Some specific examples of strategies that Malaysians would probably not have heard of or been familiar with would be flashcards. Also, certain other strategies such as "I try to talk like native speakers" or "I start conversations in English" or "I look for people I can talk to in English" are all based on the assumption that there are native speakers of English in that country. In West Malaysia, English is not the first language for the majority of the population, even though it is widely spoken especially in the urban centers. However, from the main city centers, the language is spoken less often. Also, since it is such a multi-ethnic country, one cannot just start a conversation in English. It would depend on where and who the person is. And as mentioned earlier, other strategies such as rote-learning are not specifically listed.

I decided that a questionnaire was the best instrument that I could use for the kind of study that I intended to do, given the large 
sample size. It is quicker, easier and more efficient as compared to other instruments such as the think-aloud technique. It also provides a wide range of strategies that subjects can choose from and it also lets them know of strategies that they actually use without being aware of until they see it listed. However, it would have been more revealing if follow-up interviews could have been done. Interviews might reveal not only the types and number of strategies they use but also the reasons why they use them.

\section{RECOMMENDATIONS}

In the examination of learners' strategies in West Malaysia, several recommendations are suggested on how teachers' and learners' could better improve and understand second language learning. It must be noted first that in the assessment of Malaysian learners' strategies, teachers should not rely on only one instrument, but consider a second instrument, especially one that is more Eastern-oriented, as well as follow the assessment with interviews or teacher observations.

Despite certain reservations or criticisms that were earlier leveled at Oxford's SILL, it is still in my opinion one of the best instruments devised for looking at learners' strategies. She has exhaustively listed almost all possible strategies known to learners and has conveniently categorized them into six major groups, thus making it easy for researchers and teachers to examine the strategies in different contexts. The advantage in using Oxford's SILL is that it 
has a worksheet and graph that helps explain what strategies the learners are using without making any judgements as to whether their strategies are good or bad. Learners are also able to identify their learning strategies at any given time. I would recommend that further research be done with Oxford's instrument. However, I would also either modify some of it to suit the culture it is being used in or to use it with a second instrument, interviews, teacher observations or think-aloud techniques that require student input.

I would also recommend that Oxford's SILL be used at different times of a learning period in order to make comparisons between learners' performance and the types of strategies used. The reason for doing this would be to see if their learning strategies remain stable over time. The findings may prove to be useful to teachers, learners and researchers who are interested in how performances are linked with learners' strategies. In view of this, it would be interesting to see what the results would be if the SILL were again given to the same Malaysian learners in the future.

A further recommendation in light of this study would be that both teachers and learners should be more conscious of the strategies that learners use. As can be seen from the result of this study, even though both successful and unsuccessful learners seem to use about the same number of strategies they differ on a number of them. The differences found should be isolated and studied in more detail so that certain strategies that the successful learners use can be transfered to the unsuccessful learners. For example, in this study it was found that the Malay successful learners were more inclined to 
use memory strategies than social strategies. It would seem then that memory strategies helped the successful Malay learners in language learning. As such, this particular strategy could be taught to unsuccessful Malay learners. However, this finding cannot be generalized for the Chinese or Indian ethnic groups. The Malays may be better at using memory strategies than the other two groups because of their religion. They are required, for example, to memorize parts of the Quran by rote and then quote word-by-word to the teacher. The Chinese and Indian learners may adopt other types of strategies that are more suited to them, which turned out to be the case here. But, the principle remains the same, that is the transference of strategies used by effective learners to ineffective learners can be helpful to ineffective learners.

A further recommendation that I would make is in strategy training, which has been deemed important by numerous researchers (Ehrman and Oxford, 1989; Reiss, 1981). Strategy training encompasses a wide variety of ways to help both the teacher and learner to improve their second language learning efficiency. Oxford and Ehrman (1989), for example, have suggested three ways. They believe that the training should be geared towards learners' needs, that affective factors are important and that learners should learn to develop goals for their own language learning, and this can be achieved by:

1) Assessing learners' current learning strategies, using diaries, observations, interviews etc. 
2) Determine learners' existing goals, motivations, attitudes, and personality type through informal discussions or through more formal assessment techniques.

3) Consider carefully learners' language learning experience, national origin, sex, age, and other background factors.

My study can be further expanded in the future to accommodate all three of the above suggestions. Observations and interviews, for example, could be carried out immediately after handing out Oxford's SILL questionnaire. As for the goals, motivations and attitudes of the learner, Politzer (undated) found that Oriental and Hispanic graduate students learning English were more instrumentally rather than integratively motivated. However there was little evidence of a link between strategies used and motivational orientation. Gardner and Lambert (1972) have similarly found that the type of motivation (instrumental or integrative) will vary according to the cultural setting. And as for the third suggestion, the national origin, sex, age and other background factors of these subjects were carefully considered. Studies have shown that national origin or ethnicity, for example, has a strong influence on the kinds of strategies used by language learners. For example, Oriental students seem to prefer strategies involving rote memorization and language rules as compared to communicative strategies (Politzer \& McGroarty, 1985; Tyacke \& Mendelsohn, 1986). 
A number of other recommendations were given by Reiss (1981) who believed that less successful language learners did not seem to be aware of, or have not yet found a particular learning style. This view is also shared by Stern (1974) who believes that the poor learner has little or no insight into his own learning and difficulties nor into the task he is learning at-hand. Reiss (1981) suggests ten ways for teachers to help unsuccessful language learner

1) inform students honestly about the task of learning a language, the work involved, and the rewards to be gained.

2) create the kind of classroom climate in which students feel comfortable and involved.

3) aid students in developing certain cognitive styles helpful in language learning by assigning tasks.

4) help students develop the art of inferencing by making them aware of clues for intelligent guessing.

5) personalize language instruction whenever feasible in order to motivate students to express themselves readily.

6) ask students to monitor each other's speech and thus take an active part, not only in learning, but also in teaching.

7) seek out opportunities for students to use the language outside the classroom.

8 ) present all material in a meaningful manner and, in turn, expect students to attend to both structure and meaning from the outset. 
9) ask successful language learners to serve as informants regarding strategies, techniques, and study skills.

10) encourage slow students to experiment freely until they find their own particular learning style.

The emphasis here is clearly on the teacher, and while these recommendations would definitely help the learner, I believe that more credit ought to be given to the learner. In recent studies (Oxford and Nyikos, 1989; Cohen \& Hoesenfeld, 1981), researchers believe that learners need to be more autonomous, independent and self-directed. Some of the ways this could be done were suggested by Oxford \& Nyikos (1989). For example, unsuccessful language learners should be encouraged to experiment with a variety of strategies or in a language program the learners' need should be taken into account in order that they can gain self-control and autonomy through strategy use, and so that learners' conscious awareness and use of workable strategies can be encouraged.

Also, if a similar study were to be conducted in a Pacific Rim Region, I would suggest that when trying to obtain a large sample size of different ethnic backgrounds, to select a number of schools that would provide a more equal distribution of the ethnic groups. In most South East Asian countries, for example, different geographical areas tend to be populated by different ethnic groups. My study could have produced, more statistically significant results if I had chosen two or three different schools in certain urban or rural areas. 


\section{SUMMARY}

An analysis of the background questionnaire revealed the deep - seated differences in language use of Bahasa Malaysia, English, Chinese and Indian dialects at home by the three different ethnic groups (Malays, Chinese and Indians) in West Malaysia.

The language situation has in part contributed to the differences in use of language, especially in English. Under the British influence, most of the ethnic groups that lived in the urban areas spoke English. Today, even though English is maintained in most homes, there has been a significant decline in the language proficiency and use of English at home and in schools.

With the introduction of the National Policy Act (1967), the Malaysian government relegated English to the status of second language as opposed to an official language.

In a multi-lingual and multi-cultural environment such as West Malaysia, the implementation of such a policy has had a profound impact on Malaysians' attitudes, motivation and general outlook towards English. In turn, such learner variables have had a considerable effect on the use of the language at home or in school, and the learning strategies that students use in classrooms.

This study has revealed that there are some differences in the use of strategies based on student ethnicity and there are some differences in the use of strategies between successful and unsuccessful learners. Most of these differences however are small, indicating perhaps that the strategies they use are not too different 
from each other, or they may be using other strategies that may not be mentioned in Oxford's SILL.

In the United States, practitioners are working very closely to adopt this kind of research to meet learners' needs in the classroom. In West Malaysia, unfortunately, there is no such research currently undertaken. As this study is probably one of the first of its kind being conducted in West Malaysia, there is still very little known about Malaysian learners' strategies.

In terms of language education for the $21 \mathrm{st}$ century, West Malaysia needs to first outline its goals for the people in the coming years (exactly how proficient in English does the government want the people to be), and to conduct the type of learning strategy research that may cut deep into the problems of language use in classrooms.

For West Malaysia to adopt and implement the kind of research to better meet learners' needs such as in the U.S., the Malaysian government has to see that there is such a need. As was described in my study, there is a growing need for English coupled with a declining rate in English proficiency, and as such the government definitely sees the need for improvement. As the language situation in West Malaysia worsens, the government will most likely adopt such research to meet learners' needs in the classroom. 


\section{REFERENCES}

Aznam, S. (1988). Speaking of unity: Malaysia. Far Eastern Economic Review, 19-20.

Bialystok, E. (1978). A theoretical model of second language Learning. Language Learning 28(1), $69-83$.

Brown, D. H. (1973) Affective variables in second language Acquisition. Language Learning, 23(2), 231 - 244.

Brown, A. L. (1982). Inducing strategic learning from texts by means of informed, self-control training. Topics in Learning \& Learning Disabilities, $2,1-14$.

Cohen, A. D. (1988). Malaysian students struggle to cope with language shift. The Chronicle of Higher Education, A29 - A30.

Chamot, A. U., \& O'Malley, J. M. (1990). Learning strategies in second language acquisition. Cambridge, England: Cambridge University Press.

Chamot A. U., \& Kupper, L. (1989). Learning strategies in foreign language instruction. Foreign Language Annals, 22(1), 13 - 24.

Cohen, A. D., \& Hosenfeld, C. (1981). Some uses of mentalistic data in second language research. Language Learning, 31(2), 285 313.

Gardner, R. C., \& Lambert, W. E. (1972). Attitudes and motivation in second language learning. Rowley, Ma: Newbury House Publishers. 
Huang, X. H., (1984). An investigation of learning strategies in oral communication that Chinese EFL learners in China employ. Thesis, H.K., 165 pages. Chinese University of Hong Kong.

Huang, X. H. \& Van Naerssen, M. (1987). Learning strategies for oral communication. Applied Linguistics, 8(3), 287-307.

Joefer, H. J. (1985). Insight guide to Malaysia. H.K.: Apa Productions.

Lukmani, Y (1972). Motivation to learn and language proficiency. Language Learning 22(2), 261-274.

Naiman, Neil, Maria Frohlich \& Angie Todesco. (1975). The good second language learner. TESL Talk 6, 1(1), 58-75.

Naiman, Neil, Maria Frohlich, H. H. Stern, \& Angela Todesco. (1978). The good language learner. Research in Education series 7. Toronto: Ontario Institute for Studies in Education.

Nyikos, M. (1990). Sex-related differences in adult language learning. Socialization and memory factors. Modern Language Journal, 74(3), 273 - 287.

O'Malley, J. M., Rocco P. Russo, Anna Chamot, Gloria S. Manzanares \& Lisa Kupper. (1985a). Learning strategy applications with students of English as a second language. TESOL Quarterly, 19(3), 557 - 583.

O'Malley, J. M., Anna U. Chamot, Gloria S. Manzanares, Lisa Kupper, \& Rocco P. Russo (1985b). Learning strategies used by beginning and intermediate ESL students. Language Learning, 35(1), 2147.

Omar, H. O. (1984). Language and society in Malaysia. Dewan K.L., Malaysia: Dewan Bahasa dan Pustaka, 1982. 
Oxford, R. L. \& Nyikos, M. (1988). Vive la difference? Reflections on sex differences in use of language learning strategies. Foreign Language Annals, 21(4), 321-329.

Oxford, R. L. (1989). Use of language learning strategies: A synthesis of studies with implications for strategy training. System. 17(2), 235-247.

Oxford, R. L. (1989). "The best and the worst:" An exercise to tap perceptions of language learning experiences and strategies. Foreign Language Annals, 22(5), 447-454.

Oxford, R. L., \& Crookall, D. (1989). Research on language learning strategies: Methods, findings \& instructional issues. The Modern Language Journal, 73(4), 404-417.

Oxford, R. L., \& Ehrman, M. (1989) Effects of sex differences, career choice, and psychological type on adult language learning strategies. The Modern Language Journal, 73(1), 1-13.

Oxford, R. L., \& Nyikos, M. (1989). Variables affecting choice of language learning strategies by university students. The Modern Language Journal, 73(3), 291-299.

Oxford, R. L. (1990). Language learning strategies: what every teacher should know. New York, N.Y.: Newbury House Publishers.

Oxford, R. L., \& Ehrman, M. (1990). Adult language learning styles \& strategies in an intensive training setting. The Modern Language Journal, 74(3), 311-327.

Pearson, E. (1988). Learner strategies and learner interviews. ELT Journal, 42,173-178. 
Politzer R. L. (undated) Motivation, language learning behavior, and achievement in an intensive ESL course. Unpublished manuscript, Stanford University, Stanford, CA.

Politzer, R. L., \& Mc Groarty, M. (1985). An exploratory study of learning behaviors and their relationship to gains in linguistic and communicative competence. TESOL Quarterly, 19(1), 103124.

Raymond, P. (1982). Attitude, motivation and personality in second language acquisition: From macro approach to micro approach. TESL Talk, 13(1), 45-54.

Reiss, M. A. (1981). Helping the unsuccessful language learner. Modern Language Journal, 65, 121-128.

Rubin, J. (1975). What the "good language learner" can teach us. TESOL Quarterly, 9, 41-51.

Rubin, J. (1981). Study of cognitive process in second language learning. Applied Linguistics, 2(2), 117-131.

Stern, H. H. (1974). What can we learn from the good language learner? Canadian Modern Language Review, 31, 304-318.

Stern, H. H. (1983). Fundamental concepts of language teaching. Oxford: Oxford University Press.

Stewart, O \& Tei, E (1983). Some implications of metacognition for reading instruction, Journal of Reading, 36-47.

Tollefson, J. W. (1981). The role of language planning in second language acquisition. Language Learning, 31(2), 337 - 347. 
Tyacke, M. \& Mendelsohn, D. (1986). Student needs: cognitive as well as communicative. TESL Canada Journal, 1, 171-183.

Vann, R. J., \& Abraham, R.G. (1990). Strategies of unsuccessful language learner. TESOL Quarterly, 24(2), 177-198.

Wenden, A.L. (1983a). Facilitating autonomy in language learners. TESOL Newsletter, 6, 6-7.

Wenden, A. L. (1983b). Literature review: The process of intervention. Language Learning 33(1), 103-121.

Wenden, A. L. (1985). Learner strategies, TESOL Newsletter, 19(5), $1-7$.

Wenden, A. L. (1987). Metacognition: an expanded view on the cognitive abilities of L2 learners. Language Learning, 37(4), 573-597. 
APPENDIX A

\section{BACKGROUND QUESTIONNAIRE}




\section{APPENDIX A}

\section{BACKGROUND QUESTIONNAIRE}
1. Date
2. Age
3. Form
4. Sex
5. Mother tongue
6. Address (present)

7. How long have you lived at the address in \#6?

8. Address (parents). If it is the same as \#6, write "same". If not, write address in full.

9. How long have you lived at the address in \#8?

10. Race (Malay, Chinese, Indian etc)

11. Language(s) you speak at home

12. How long have you been studying English?

13. How do you rate your overall proficiency in English as compared with the proficiency of other students in your class? (Circle one)

Excellent Good Fair $\quad$ Poor

14. How do you rate your overall proficiency in English as compared with the proficiency of native speakers of the language? (Circle one).

Excellent Good Fair Poor

15. How important is it for you to become proficient in English? (Circle one)

Very important Important Not so important 
16. Why do you want to learn English? Choose all that apply to you. Then place a number to each of your choices. The most important is 1 and the least important a 7. Please make sure there is a number to each of your choices.

interested in the language
interested in the culture
have friends who speak the language
$\begin{aligned} & \text { required to take a language course to } \\ & \text { graduate }\end{aligned}$
need it or my future career
need it for travel
other (list):

17. Do you enjoy language learning? (Circle one):
Yes
No
Sometimes
Don't know

18. Do you enjoy learning English? (Circle one):
Yes
No
Sometimes
Don't know

19. What other languages have you studied?

20. What has been your experience (good, neutral, not good) while studying English? Why? Please explain or describe. 
For your teacher:

Comments if any:

Cut here:

Name of student: 


\section{APPENDIX B}

TRANSLATED BACKGROUND QUESTIONNAIRE 
APPENDIX B

TRANSLATED BACKGROUND QUESTIONNAIRE

LATAR BELAKANG QUESTIONNAIRE

1. Tarikh

2. Umur

3. Tingkatan

4. Jantina

6. Alamat (sekarang)

5. Bahasa Asli

7. Berapa lama telah kamu tinggal di alamat \#6?

8. Alamat (ibubapa). Jika sama dengan \#6, tulis "sama." Jika tidak, tuliskan alamat penuhnya.

9. Berapa lama telah kamu tinggal di alamat \#8?

10. Bangsa (Melayu, Cina, Indian, etc..)

11. Bahasa yang kamu gunakan di rumah

12. Berapa lama telah kamu belajar Bahasa Inggeris?

13. Bagaimana kamu agak kecekapan kamu dalam Bahasa Inggeris bila berbanding dengan kecekapan pelajar-pelajar lain.? (Pilih satu)

Teramat baik Baik Sederhana Tak baik

14. Bagaimana kamu agak kecekapan kamu dalam Bahasa Inggeris bila berbanding dengan penutur-penutur dari bahasa itu. (Pilih satu)

Teramat baik Baik Sederhana Tak baik

15. Bagaimana mustahaknya bagi kamu supaya menjadi lebih cekap dalam Bahasa Inggeris? (Pilih satu) 
Sangat mustahak Mustahak

Tidak begitu mustahak

16. Mengapa kamu hendak belajar Bahasa Inggeris? Pilih semua yang berkenaan dengan kamu. Kemudian tulis satu nombor kepada tiaptiap pilihan kamu. Ia bermula dengan nombor satu hingga nombor 7. Nombor yang sangat mustahak ialah nombor 1 dan yang tidak mustahak ialah nombor 7 . Tiap-tiap pilihan kamu mesti ada satu nombor.

Minatnya dengan Bahasa itu.

Minat dengan kebudayaannya.

Ada kawan yang cakap Bahasa itu.

Perlu mengambil Bahasa itu untuk lulus dari sekolah.

Perlu mengambilnya untuk kerjaya.

Perlu untuk mengembara

Yang lain-lain:

17. Sukakah kamu belajar Bahasa-bahasa lain? Bulatkan satu:

Ya Tidak Kadang-kadang

Tidak tahu

18. Sukakah kamu belajar Bahasa Inggeris? Bulatkan satu:

Ya Tidak Kadang-kadang Tidak tahu

19. Apakah Bahasa-bahasa lain yang telah kamu belajar?

20. Apakah pengalaman (bagus, neutral, tidak bagus) kamu semasa mempelajari Bahasa Inggeris? Mengapa? Sila terangkan. 


\section{BERHENTI}

Bagi Guru Kamu:

Comment (Ulasan) jika ada:

Gunting sini:

Nama Pelajar: 


\section{APPENDIX C}

STRATEGY INVENTORY FOR LANGUAGE LEARNING 


\section{APPENDIX C \\ Strategy Inventory for Language Learning \\ Version 5.1 \\ (c) R. Oxford, 1989}

\section{Directions}

This form of the STRATEGY INVENTORY FOR LANGUAGE LEARNING (SILL) is for students of English as a second or foreign language. You will find statements about learning English. Please read each statement. On the separate Worksheet, write the response $(1,2,3,4$, or 5) that tells HOW TRUE OF YOU THE STATEMENT IS.

1. Never or almost never true of me

2. Generally not true of me

3. Somewhat true of me

4. Generally true of me

5. Always or almost always true of me

NEVER OR ALMOST NEVER TRUE OF ME means that the statement is very rarely true of you;

USUALLY NOT TRUE OF ME means that the statement is true less than half the time.

SOMEWHAT TRUE OF ME means that the statement is true of you about half the time;

USUALLY TRUE OF ME means that the statement is true more than half the time.

ALMOST OR ALMOST ALWAYS TRUE OF ME means that the statement is true of you almost always.

Answer in terms of how well the statement describes you. Do not answer how you think you should be, or what other people do. 
There are no right or wrong answers to these statements. Put your answers on the separate Worksheet. Please make no marks on the items. Work as quickly as you can without being careless. This usually takes about $20-30$ minutes to complete. If you have any questions, let the teacher know immediately.

\section{EXAMPLE}

1. Never or almost never true of me

2. Usually not true of me

3. Somewhat true of me

4. Usually true of me

5. Always or almost always true of me

Read the item, and choose a response ( 1 through 5 as bove), and write it in the space after the item.

I actively seek out opportunites to talk with native speakers of English.

You have just completed the complete item. Answer the rest of the items on the Worksheet.

Strategy Inventory for Language Learning Version 5.1

(c) R. Oxford, 1989

1. Never or almost never true of me

2. Usually not true of me

3. Somewhat true of me

4. Usually true of me

5. Always or almost always true of me

(Write answers on Worksheet) 


\section{Part A}

1. I think of relationships between what I already know and new things I learn in English.

2. I use new English words in a sentence so I can remember them.

3. I connect the sound of a new English word and an image or picture of the word to help me remember the word.

4. I remember a new English word by making a mental picture of a situation in which the word might be used.

5. I use rhymes to remember new English words.

6. I use flashcards to remember new English words.

7. I physically act out new English words.

8. I review English lessons often.

9. I remember new English words or phrases by remembering their location on the page, on the board, or on a street sign.

\section{$\underline{\text { Part B }}$}

10. I say or write new English words several times.

11. I try to talk like native English speakers.

12. I practice the sounds of English.

13. I use the English words I know in different ways.

14. I start conversations in English.

15. I watch English language TV shows spoken in English or go to movies spoken in English.

16. I read for pleasure in English.

17. I write notes, messages, letters, or reports in English.

18. I first skim an English passage (read over the passage quickly) then go back and read carefully.

19. I look for words in my own language that are similar to new words in English.

20. I try to find patterns in English.

21. I find the meaning of an English word by dividing it into parts that I understand.

22. I try not to translate word-for-word.

23. I make summaries of information that $I$ hear or read in English.

\section{$\underline{\text { Part C }}$}

24. To understand unfamiliar English words, I make guesses. 
25. When I can't think of a word during a conversation in English, I use gestures.

26. I make up new words if I do not know the right ones in English.

27. I read English without looking up every new word

28. I try to guess what the other person will say next in English.

29. If I can't think of an English word, I use a word or phrase that means the same thing.

\section{$\underline{\text { Part D }}$}

30. I try to find as many ways as I can to use my English.

31. I notice my English mistakes and use that information to help me do better.

32. I pay attention when someone is speaking English.

33. I try to find out how to be a better learner of English.

34. I plan my schedule so I will have enough time to study English.

35. I look for people I can talk to in English.

36. I look for opportunities to read as much as possible in English.

37. I have clear goals for improving my English skills.

38. I think about my progress in learning English.

\section{$\underline{\text { Part E }}$}

39. I try to relax whenever I feel afraid of using English.

40. I encourage myself to speak English even when I am afraid of making a mistake.

41. I give myself a reward or treat when I do well in English.

42. I notice if I am tense or nervous when I am studying or using English.

43. I write down my feelings in a language learning diary.

44. I talk to someone else about how I feel when I am learning English.

\section{$\underline{\text { Part F }}$}

45. If I do not understand something in English, I ask the other person to slow down or say it again.

46. I ask English speakers to correct me when I talk.

47. I practice English with other students.

48. I ask for help from English speakers. 
49. I ask questions in English.

50. I try to learn about the culture of English speakers. 
Worksheet for Answering and Scoring the Strategy Inventory for Language Learning (SILL)

Version 7.0 (ESL/EFL)

(c) R. Oxford,1989

1. The blanks (__ are numbered for each item on the SILL.

2. Write your response to each item (that is, write $1,2,3,4$ or 5 ) in each of the blanks.

3. Add up each column. Put the result on the line marked SUM.

4. Divide by the number under SUM to get the average for each column. Round this average off to the nearest tenth, as in 3.4 .

5. Figure out your overall average. To do this, add up all the SUMS for the different parts of the SILL. Then divide by 50 .

6. When you have fininshed, your teacher will give you the Profile of Results. Copy your averages (for each part and for the whole SILL) from the Worksheet to the Profile. 
SILL Worksheet

Version 7.0 (ESL/EFL)

(c) R. Oxford, 1989

Bah. Bah Bah. Bah. Bah. Bah.

$\begin{array}{llllll} & & & & \\ \text { A } & \text { B } & \text { C } & \text { D } & \text { E } & \text { F }\end{array}$

1.

10. 24.

30. 39 . 39

45.

Jumlah Bah.A

2.

11.

25.

31.

40.

46.

Jumlah Bah. B

3.

12. 26 .

32.

41.

47.

Jumlah Bah. C

4.

13. _ 27.

33.

42.

48. Jumalh Bah. D

5.

14. - $28 .-34$.

43.

49. Jumlah Bah. E

35.

44.

50. Jumlah Bah. F

29.

36.

7.

16.

37.

8.

17.

9.

18.

38.

19.

20.

21.

22.

23. 


\begin{tabular}{|c|c|c|c|c|c|}
\hline Jumlah & $\underset{\mathrm{h}}{\mathrm{Jum}} \mathrm{lah}$ & Jumlah & Jumlah & Jumlah & Jumlah \\
\hline $9=$ & $14=$ & $6=$ & $9=$ & $6=$ & $6=$ \\
\hline $50=$ & & & & & \\
\hline
\end{tabular}

(Seluruh Markah

Pertengahan) 
Profile of Results on the Strategy Inventory for Language Learning (SILL)

\author{
Version 7.0 (ESL/EFL) \\ (c) R. Oxford, 1989
}

You will receive this Profile after you have completed the Worksheet. This Profile will show your SILL results. These results will tell you the kinds of strategies you use in learning English. There are no right or wrong answers.

To complete this Profile, transfer your averages for each part of the whole SILL. These averages are found on the Worksheet.

Part What Strategies Are Covered Your Ave. on this Part
A. Remembering More Effectively
B. Using Your Mental Processes
C Compensating for missing knowledge
D Organizing and Evaluating Your Learning
E Managing Your Emotions
F. Learning with others

YOUR OVERALL AVERAGE 
SILL Profile of Results (continued)

Version 7.0

(c) R. Oxford, 1989

Key to Understanding Your Averages

$\begin{array}{llr}\text { High } & \text { Always or almost always used } & 4.5 \text { to } 5.0 \\ & \text { Usually used } & 3.5 \text { to } 4.4 \\ \text { Medium } & \text { Sometimes used } & 2.5 \text { to } 3.4 \\ \text { Low } & \text { Generally not used } & 1.5 \text { to } 2.4 \\ & \text { Never or almost never used } & 1.0 \text { to } 1.4\end{array}$

Graph Your Averages Here

If you want, you can make a graph of your SILL averages. What does this graph tell you? Are you very high or very low on any part?

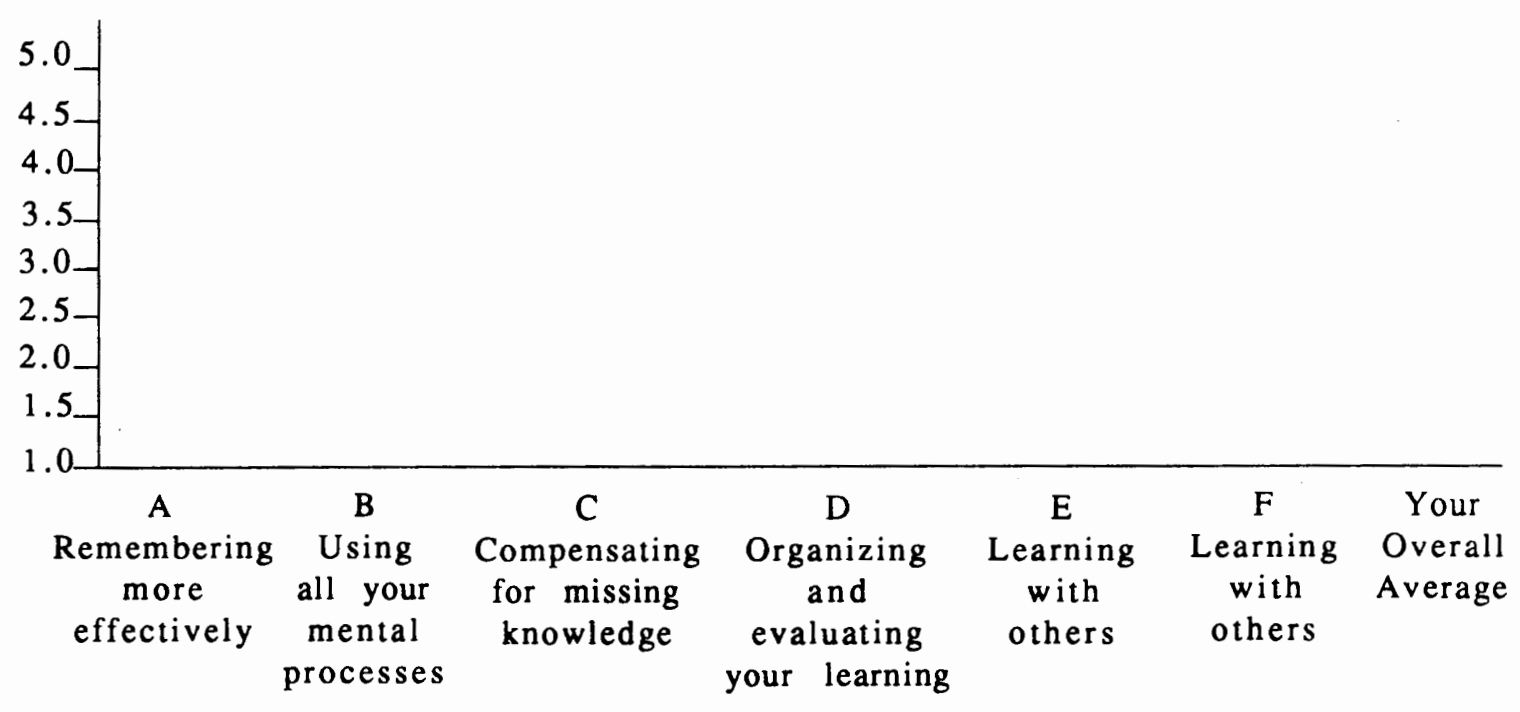

What These Averages Means to You

The overall average tells how often you use strategies for learning English. Each part of the SILL represents a group of learning strategies. The averages for each part of the SILL show which groups of strategies you use the most for learning English.

The best use of strategies depends on your age, personality, and purpose for learning. If you have a very low average on one or 
more parts of the SILL, there may be some new strategies in these groups that you might want to use. Ask your teacher about these. 
APPENDIX D

TRANSLATED SILL VERSION 


\section{APPENDIX D}

\section{TRANSLATED SILL VERSION}

Strategy Inventori bagi Pelajaran Bahasa (SILL)

Version 7.0 (ESL/EFL)

(c) R. Oxford, 1989

\section{Arahan}

Borang Strategy Inventory bagi Pelajaran Bahasa (SILL) ini di persiapkan untuk pelajar-pelajar ESL. Kamu akan dapat penyataan tentang pelajaran Inggeris. Sila bacakan tiap-tiap penyataan. Dalam kertas Worksheet yang asing, terangkan pendapat kamu $(1,2,3,4$, atau 5) yang menunjukkan kebenaran penyataan itu tentang kamu.

1. Tidak atau hampir tidak benar tentang saya.

2. Biasanya tidak benar tentang saya.

3. Sedikit benar tentang saya.

4. Biasanya benar tentang saya.

5. Selalu atau hampir selalu benar tentang saya.

TIDAK ATAU HAMPIR TIDAK BENAR TENTANG SAYA, maknanya penyataan itu biasanya tidak benar tentang saya.

BIASANYA TIDAK BENAR TENTANG SAYA, maknanya penyataan itu hanya benar kurang daripada setengah masanya.

SEDIKIT BENAR TENTANG SAYA, maknanya penyataan itu hanya benar tentang kamu sekurang setengah masanya.

BIASANYA BENAR TENTANG SAYA, maknanya penyataan itu benar lebih dari setengah masanya.

SELALU ATAU HAMPIR SELALU BENAR TENTANG SAYA, maknanya penyataan itu benar tentang kamu hampir selalunya. 
Jawab dan terangkan bagaimana tepatnya penyataan itu dengan diri kamu. Hanya jawab apa yang kamu pratikkan dan jangan jawab apa yang kamu fikir kamu lakukan, atau apa yang orang lain buat. Tidak adanya jawapan yang betul atau salah dalam penyataan-penyataan ini. Tuliskan jawapan kamu dalam kertas Worksheet yang asing. Tolong jangan tulis markah yang lain di kertas itu. Kerjalah dengan secepat mungkin tanpa membuat silap. Kerja ini biasanya akan mengambil selama 20-30 minit untuk selesai. Jikalau kamu ada soalan, silalah beritahu guru kamu secepat mungkin. 


\section{CONTOH}

Saya mencari peluang untuk bercakap bahasa Inggeris dengan penutur.

Di mukasurat ini, tandakan " $X$ " di tempat yang kosong di bawah penyataan yang menunjukkan apa yang kamu akan benar lakukan berkenaan Inggeris sekarang.

Tidak Biasanya tidak Sedikit benar Biasanya Selalu atau at au hampir benar tentang tentang saya saya benar hampir tentang selalu tidak

\section{tidak}

1 2

3 saya benar tentang saya

4 5

Jikalau kamu sudah jawap soalan di atas, kamu sudah selesai menjawap contoh ini.

Sekarang, sila tunggu hingga guru kamu memberi isyarat untuk meneruskan soalan-soalan lain. Bila menjawap soalan-soalan, kerjalah berhati-hati tetapi dengan cepat. Tandalah jawapanjawapan kamu di kertas Worksheet yang asing, bermula dengan soalan 1 
Strategy Inventori bagi Pelajaran Bahasa

Version 7.0 (ESL/EFL)

(c) R. Oxford, 1989

1. Tidak atau hampir tidak benar tentang saya.

2. Biasanya tidak benar tentang saya

3. Sedikit benar tentang saya.

4. Biasanya benar tentang saya

5. Selalu atau hampir selalu benar tentang saya.

(Tuliskan jawapan kamu di dalam Worksheet)

Seksyen A

1. Saya fikir akan perhubungan di antara apa yang saya sudah tahu dengan perkara baru yang telah saya belajar dalam Bahasa Inggeris.

2. Saya menggunakan perkataan Inggeris baru dalam sesuatu ayat supaya saya boleh mengingatinya.

3. Saya membuat perhubungan dengan bunyi dari perkataan Inggeris baru dengan sesuatu gambar dari perkataan itu untuk menolong peringatan saya.

4. Saya mengingat sesuatu ayat Inggeris baru dari dengan membuat gambaran daripada situasi itu dari mana perkataan itu mungkin di gunakan.

5. Saya mengguna "rima" untuk mengingati perkataanperkataan Inggeris baru.

6. Saya mengguna "flashcards" untuk mengingati perkataanperkataan Inggeris baru.

7. Saya melakunkan perkataan Inggeris baru yang saya belajar.

8. Saya rajin mengulang pelajaran Inggeris. 
9. Saya mengingati perkataan-perkataan Inggeris baru dari peringatan saya tentang tempat di dalam mukasurat itu, dari papan-hitam atau pun dari isyarat lalulintas.

Seksyen B

10. Saya bercakap atau menulis berkali-kali perkataan Inggeris baru.

11. Saya mencuba bercakap seperti orang penutur.

12. Saya berlatih bunyi Inggeris.

13. Saya menggunakan perkataan Inggeris yang saya belajar dengan berbagai cara.

14. Saya memulakan perbualan dalam Bahasa Inggeris.

15. Saya melihat program Inggeris di televisyen, atau pergi menonton filem Inggeris.

16. Saya membaca buku Bahasa Inggeris untuk keseronakannya.

17. Saya mengambil nota, membuat lapuran dan menulis surat dalam bahasa Inggeris.

18. Pertama, saya membaca perenggan itu dengan cepat dan kemudian ulang sekali lagi dan akhirnya membaca dengan hati-hati.

19. Saya mencari perkataan-perkataan dalam bahasa saya sendiri yang ada persamman dengan perkataan-perkataan Inggeris baru itu.

20. Saya mencuba cari "patterns" dalam Bahasa Inggeris.

21. Saya mencari makna ayat Inggeris itu dengan membahagikannya ke dalam bahagian-bahagian yang saya fahamkan.

22. Bila membuat terjemahan, saya elak daripada terjemahkan tiap-tiap perkataan. 
23. Saya membuat ringkasan dari maklumat yang saya dengar atau baca dalam Bahasa Inggeris.

\section{Seksyen C}

24. Untuk memahami perkataan Inggeris yang tidak biasa, saya mengagak sahaja.

25. Bila saya tidak boleh ingat akan sesuatu perkataan di dalam perbualan Inggeris, saya menggunakan "gestures".

26. Saya membuat perkataan-perkataan baru saya sendiri bila saya tidak tahu perkataan-perkataan Inggeris yang betul.

27. Saya membaca Bahasa Inggeris tanpa menyemak ayat-ayat baru.

28. Saya cuba mengagak apa yang akan di katakan oleh orang-orang lain dalam Bahasa Inggeris.

29. Bila saya tidak boleh ingat perkataan Inggeris itu, saya gunakan sesuatu perkataan lain yang sama maknanya.

\section{Seksyen D}

30. Saya mencuba dengan sedaya untuk mengguna Bahasa Inggeris.

31. Saya sedar akan kesilapan saya dan menggunakan kesilapan itu untuk menolong saya menjadi lebih cekap.

32. Saya mendengar baik-baik bila seseorang bercakap Inggeris.

33. Saya mencuba cari bagaimananya saya boleh menjadi seseorang pelajar Inggeris yang baik.

34. Saya merancang waktu saya dengan supaya saya ada cukup masa untuk belajar Bahasa Inggeris. 
35. Saya mencari orang yang boleh bercakap Inggeris untuk berbual-bual.

36. Saya mencari berbagai-bagai peluang untuk membaca dengan banyaknya buku Bahasa Inggeris.

37. Saya ada matlamat yang terang untuk mengelokkan Inggeris saya.

38. Saya memikir tentang kemajuan saya bila saya belajar Inggeris.

\section{Seksyen E}

39. Saya mencuba legakan diri apabila saya takut menggunakan Inggeris.

40. Saya menggalakkan diri sendiri untuk bercakap Inggeris bila saya takut membuat kesilapan.

41. Saya memberikan hadiah pada diri sendiri apabila saya menggunakan Bahasa Inggeris dengan betul.

42. Saya sedar kebimbangan saya, bila saya sedang belajar atau menggunakan Inggeris.

43. Saya mencatatkan perasaan saya dalam buku catatan pelajaran Bahasa.

44. Saya bercakap dengan orang lain tentang perasaan saya bila saya belajar Inggeris.

\section{Seksyen F}

45. Bila saya tidak faham tentang sesuatu dalam Inggeris, saya minta orang lain supaya bercakap perlahan-lahan atau mengulangkannya lagi.

46. Saya meminta orang yang bercakap Inggeris untuk memperbaiki Inggeris saya bila saya bercakap. 
47. Saya berlatih Bahasa Inggeris saya dengan pelajar-pelajar lain.

48. Saya meminta pertolongan dari orang penutur.

49. Saya menanya soalan-soalan dalam Inggeris.

50. Saya mencuba belajar tentang kebudayaan orang penutur. 
Worksheet Untuk Jawapan dan Strategy Inventory bagi Pelajaran Bahasa (SILL)

Version 7.0 (ESL/EFL)

(c) R. Oxford, 1989

1. Di tempat kosong (__ tiap-tiap soalan telah di nomborkan dalam SILL.

2. Tuliskan jawapan kamu bagi tiap-tiap soalan (iaitu, tulis $1,2,3,4$ atau 5) di dalam tempat kosong.

3. Kirakan tiap-tiap ruang. Tuliskan keputusan di atas garisan yang bertanda JUMLAH.

4. Bahagikan dengan numbor di bawah JUMLAH untuk mendapat markah pertengahannya (average) bagi tiap-tiap ruang. Bulatkan markah pertengahan ini kepada nombor yang sedekat dengannya, contoh 3.4 .

5. Jumlahkan semua markah pertengahan kamu bagi tiap-tiap bahagian SILL itu. Kemudian bahagikannya dengan 50 .

6. Bila kamu sudah selesai, guru kamu akan memberikan kamu Bahagian Profile Keputusan. Pindahkan markah pertengahan kamu (bagi tiap-tiap bahagian dan juga bagi keseluruhan SILL) dari Worksheet kepada Profile. 


\section{SILL Worksheet \\ Version 7.0 (ESL/EFL) \\ (c) R. Oxford, 1989}

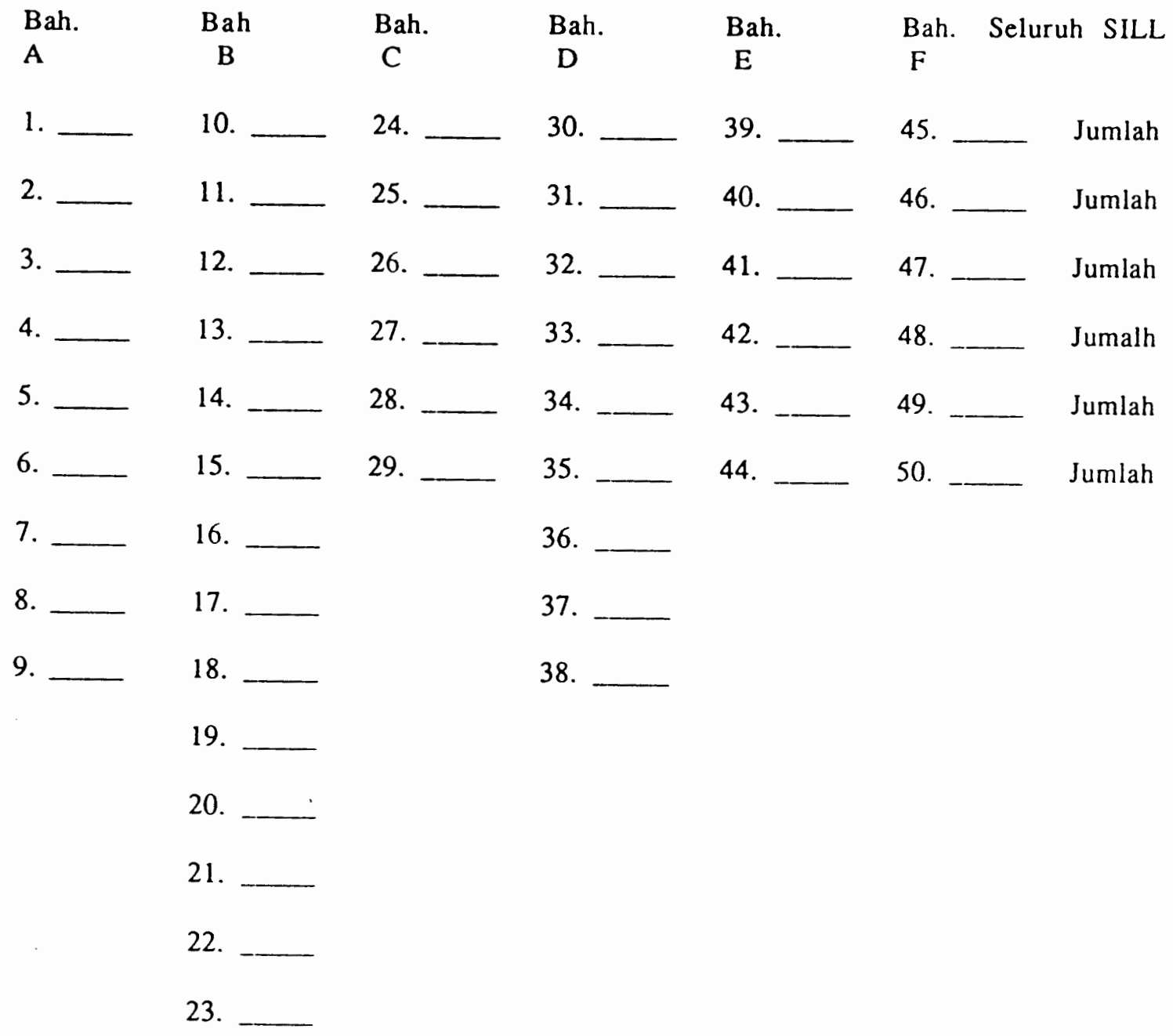

\begin{tabular}{|c|c|c|c|c|c|c|}
\hline Jumlah & Jumlah & Jumlah & Jumlah & Jumlah & Jum lah & Jumlah \\
\hline $9=$ & $14=$ & $6=$ & $\overline{9=}$ & $6=$ & $6=$ & $50=$ \\
\hline
\end{tabular}

Pertengahan) 


\section{Profile Keputusan bagi SILL Bahagian. 7.0 (ESL/EFL) \\ (c) R. Oxford, 1989}

Kamu akan terima Profile ini setelah kamu habis dengan Worksheet ini. Profile ini akan menunjuk keputusan SILL kamu. Keputusan ini akan memberitahu kamu strategies-strategies yang kamu gunakan bila membelajar Inggeris. Tidak adanya jawapan yang betul atau salah.

Untuk menghabiskan Profile ini, markah pertengahan bagi tiap-tiap bahagian dalam SILL kamu. Markah pertengahan ini boleh di dapati dari Worksheey kamu.

Bah. Strategies
A. Mengingat dengan lebih tepat
B.
Mengguna Mental Processi kamu
C
Mengurus hilang ilmu
D. Mengurus dan mengnilai pelajaran
E Mengurus perasaan kamu
F. Membelajar dengan orang lain
Seluruh Markah pertengahan kamu

Markah Pertengahan bagi bah. ini. 


\section{SILL Profile Keputusan \\ Version 7.0 \\ (c) R. Oxford, 1989}

\section{Untuk Memahami Pertengahan kamu}

\section{Tinggi \\ Sederhan a \\ Rendah}

\begin{abstract}
Selalu atau hampir selalu di gunakan $4.5-5.0$ Hampir selalu di gunakan Biasanya di gunakan Biasanya tidak di gunakan

Tidak atau hampir tidak di gunakan

$3.5-4.4$

$2.5-3.4$

$1.5-2.4$

$1.0-1.4$

Graphkan Markah Pertengahan kamu di sini
\end{abstract}

Jika kamu hendak, kamu boleh membuatkan graph bagi SILL markah pertengahan kamu. Apakah graph ini katakan tentang kamu? Adakah kamu sangat tinggi atau sangat rendah di mana-mana bahagian?

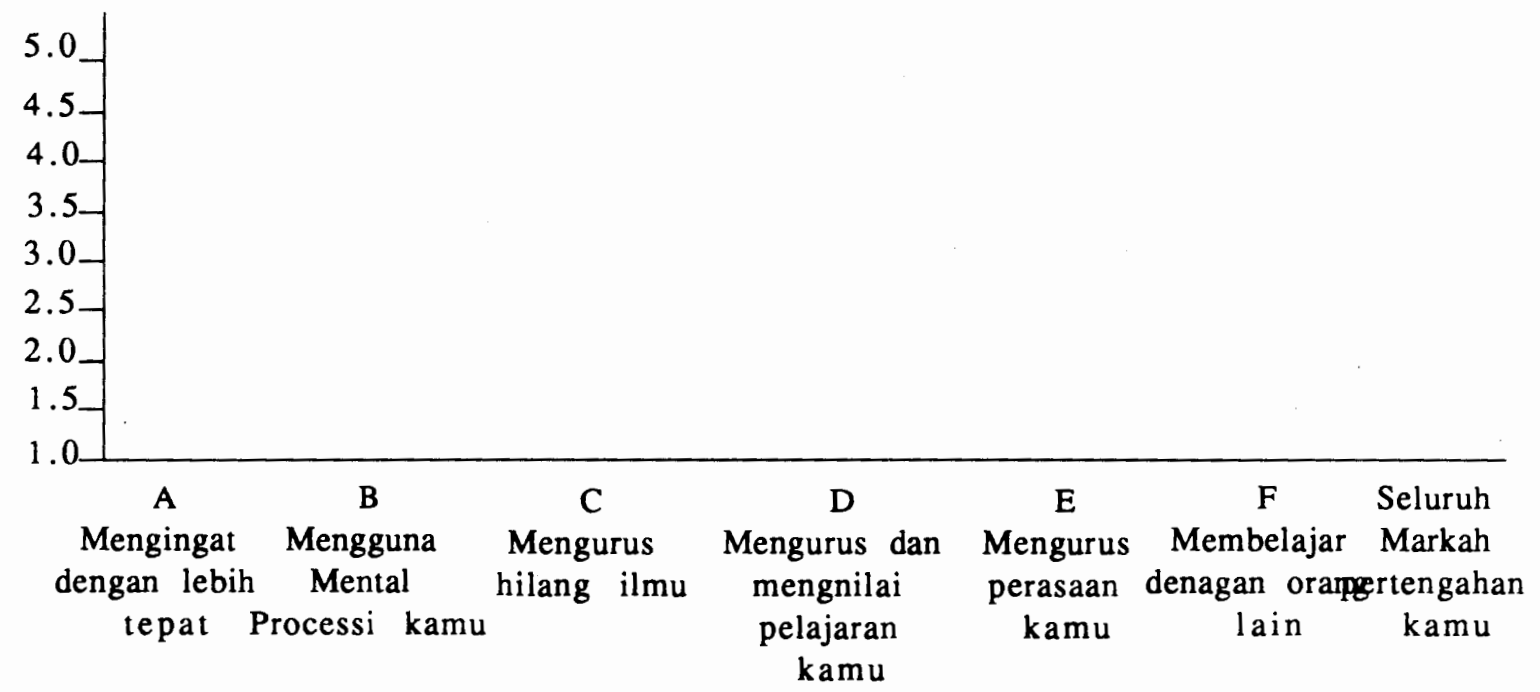

\section{Apakah Markah Pertengahan ini katakan tentang kamu.}

Markah pertengahan memberitahu kamu bagaimana kalinya kamu gunakan strategies bila mempelajari Bahasa Inggeris. Tiap-tiap bahagian dari SILL ini mengandungi satu bahagian strategies. Markah Pertengahan bagi tiap-tiap bahagian SILL menunjukkan kamu, strategies yang kamu biasanya gunakan bila membelajar Bahasa Inggeris.

Strategies yang bagus digunakan gantung akan umur, personality, dan ketujuan kamu mengapa membelajarnya. Jika kamu ada markah pertengahan yang sangat rendah dalam satu atau lebih bahagian dalam SILL, mungkin adanya strategies baru dalam bahagian ini yang kamu mungkin hendak menggunakan. Tanyalah guru kamu tentang ini. 
APPENDIX E

UNTRANSLATABLE WORDS 


\section{APPENDIX E}

\section{UNTRANSLATABLE WORDS}

An explanation of the untranslatable words.

Penjelasan bagi perkataan-perkataan yang susah di jemahkan.

1. Rhymes: means using certain lyrics or words that sound the same or that goes together in tune.

maknanya kamu menggunakan perkataanperkataan yang mempunyai bunyi yang sama.

2. Flashcards: means using cards that contain English vocabulary to help you remember them.

maknanya kamu menggunakan kad yang ada perkataan Inggeris untuk menolong kamu mengingatkannya.

3. Gestures: means using certain movements of your hands to illustrate some word.

maknanya - menggunakan sesuatu gerakan dengan tangan kamu untuk menunjukkan sesuatu perkataan.

4. Patterns: means looking for some kind of structure that repeats.

maknanya - mencari sesuatu strukture yang mengulang. 


\section{APPENDIX F}

STATEMENTS/STRATEGIES USED MOST OFTEN 


\section{APPENDIX F}

\section{STATEMENTS/STRATEGIES USED MOST OFTEN}

\begin{tabular}{|c|c|}
\hline Subjects & Statements/Strategies used most often \\
\hline 1 & $\begin{array}{l}2,3,10,14,15,16,17,18,21,22,23,24,25,28 \\
29,32,33,36,37,45,48,49,50\end{array}$ \\
\hline 2 & $\begin{array}{l}1,3,4,9,14,15,16,17,18,21,23,24,25,26,27 \\
28,29,30,32,33,35,36,37,38,40,45,49\end{array}$ \\
\hline 3 & $\begin{array}{l}1,2,3,4,8,9,12,14,15,16,17,19,21,23,24,25 \\
29,30,31,32,33,36,37,38,45,46,47,49,50\end{array}$ \\
\hline 4 & $\begin{array}{l}2,4,9,10,14,15,16,18,21,22,24,27,28,29,30 \\
31,32,33,36,45,48,49\end{array}$ \\
\hline 5 & $\begin{array}{l}1,2,13,14,15,16,17,21,22,23,28,29,30,31 \\
33,36,37,38,45,49\end{array}$ \\
\hline 6 & $\begin{array}{l}1,2,4,13,14,15,16,17,18,22,24,25,26,27,28 \text {, } \\
29,30,31,32,33,36,37,45,49,50\end{array}$ \\
\hline 7 & $\begin{array}{l}4,10,12,13,14,15,16,17,21,22,23,24,25,27 \\
28,29,30,31,32,36,37,45,47,49\end{array}$ \\
\hline 8 & $\begin{array}{l}3,13,14,15,16,17,18,22,27,29,30,31,32,33 \\
36,45,49\end{array}$ \\
\hline 9 & $14,15,16,22,24,27,29,32,33,38,40,45$ \\
\hline 10 & $1,2,13,14,15,16,21,28,36,37,45,49$ \\
\hline 11 & $\begin{array}{l}1,2,10,13,14,15,16,17,18,21,23,28,29,30 \\
31,32,36,40,45,49\end{array}$ \\
\hline
\end{tabular}




\begin{tabular}{|c|c|}
\hline 12 & $\begin{array}{l}1,13,14,15,16,17,21,23,24,25,27,28,29,30 \\
32,36,37,40,45,48,49\end{array}$ \\
\hline 13 & $\begin{array}{l}1,2,4,8,9,13,14,15,16,17,18,21,22,23,24,25 \\
27,28,29,30,31,32,33,35,36,37,40,45,49\end{array}$ \\
\hline 4 & $\begin{array}{l}1,3,4,5,10,13,14,15,16,17,18,20,21,22,23 \\
24,25,26,27,28,29,30,31,32,33,35,36,37,40 \\
45,49\end{array}$ \\
\hline 5 & $\begin{array}{l}1,2,3,4,13,14,15,16,17,18,21,22,23,25,28 \\
29,30,31,32,33,35,36,37,38,45,49,50\end{array}$ \\
\hline 6 & $\begin{array}{l}1,2,4,11,13,14,15,16,18,22,25,28,30,31,36 \\
38,39,40,42,49,50\end{array}$ \\
\hline 7 & $\begin{array}{l}14,15,16,17,21,25,27,28,29,30,31,32,33,37 \\
40,45,49\end{array}$ \\
\hline 8 & $\begin{array}{l}4,14,15,16,17,18,21,22,29,30,31,32,33,36 \\
37,45,48,49,50\end{array}$ \\
\hline 19 & $\begin{array}{l}3,9,13,14,15,16,17,18,21,22,25,29,30,31, \\
32,33,36,37,45,47,48,49\end{array}$ \\
\hline 0 & $\begin{array}{l}1,3,4,7,10,13,14,15,16,17,18,21,22,23,24,25 \text {, } \\
26,27,28,29,30,31,32,33,36,37,40,45,49\end{array}$ \\
\hline 1 & $\begin{array}{l}6,10,14,15,17,18,21,28,29,32,33,36,37,45 \\
48,49\end{array}$ \\
\hline 0 & $\begin{array}{l}3,12,13,14,15,16,17,18,19,21,22,23,24,25 \\
29,30,31,33,36,37,45,48,49\end{array}$ \\
\hline 23 & $\begin{array}{l}1,14,15,17,18,24,25,27,29,30,31,32,33,36 \\
37,40,44,45,49\end{array}$ \\
\hline 24 & $\begin{array}{l}1,2,4,10,13,14,15,17,22,29,30,31,33,36,38 \\
40,45,47,49\end{array}$ \\
\hline
\end{tabular}


$2,4,13,14,15,17,18,21,22,23,24,30,32,36$, $38,40,49$

26

$1,3,9,10,14,15,16,17,18,23,24,25,28,29,30$, $31,36,37,38,45,47,49$

$2,4,13,14,15,16,17,18,21,24,25,27,29,30$, $31,32,33,34,36,37,45,49$

$1,2,3,4,13,14,15,16,17,18,21,24,25,27,29$, $30,31,32,36,37,38,39,40,45,49$

$1,2,4,13,17,18,19,21,24,26,27,28,29,31,33$, $38,39,40,42,49$

$1,2,8,10,13,15,16,18,22,29,30,31,33,36,37$, 38,47

$15,16,1724,25,26,27,28,29,36$

$1,13,14,15,16,17,18,22,24,25,27,28,29,32$, $33,35,36,37,38,45,49$

$3,4,5,6,13,14,15,16,18,24,25,27,28,29,30$, $31,32,33,36,37,40,45,49$

34

$13,14,15,16,17,27,36,37,49$

35

$4,14,15,16,17,21,24,25,27,28,30,33,36,37$, $38,49,50$

36

$1,9,14,15,16,17,18,24,25,28,29,30,31,36$, $37,41,43,45,49$

$1,2,3,4,12,13,14,15,16,17,21,23,25,28,29$, $30,31,32,33,35,37,38,45,46,47,49$ $25,26,27,28,29,30,33,35,36,37,38,40,49,50$ 


\section{9}

40

41

42

43

44

45

46

47

48

49

50

51

52

53
$7,8,9,11,14,15,16,17,22,24,25,26,27,28,30$, $31,36,40,45,49$

$4,7,8,9,11,13,14,15,16,17,23,24,25,29,30$, $31,32,33,36,37,38,45,49$

$1,9,14,15,16,17,22,24,25,27,28,29,31,35$, $36,37,38,40,42,49$

$1,2,3,4,8,10,13,14,15,15,16,17,18,21,22,24$, $25,27,28,29,30,31,32,33,36,37,38,45,48,49$, 50

$13,14,15,16,17,18,21,22,23,24,29,30,39$

$2,10,13,14,15,16,17,27,28,29,30,31,37,38$, $43,45,49,50$

$1,2,3,4,9,14,15,16,17,20,21,23,25,28,29,30$, $31,32,33,36,37,38,45,47,49$

$9,14,15,28,30,31,32,36,37,38,40,45,49$

$1,3,4,8,13,14,15,16,17,18,21,22,23,27,28$, $29,30,31,32,36,37,38,40,45,49,50$

$1,13,14,15,16,17,22,27,28,30,31,45,49$

$1,2,3,13,14,15,16,17,21,22,23,24,28,29,30$, $31,33,35,36,37,38,45,49$

$14,15,16,25,27,28,30,33,37,45,49$,

$2,4,9,13,14,15,16,17,21,24,25,26,28,29,30$, $33,36,37,45,49$

$4,8,9,13,15,19,23,25,27,29,30,31,32,35,37$, $38,42,44,46$

$3,4,6,10,18,24,25,27,28,29,30,31,32,33,42$ 
54

55

56

57

58

59

60

61

62

63
$1,2,9,12,14,15,16,18,19,25,30,31,32,33,35$, $36,37,38,39,40,42,45,47,49$

$2,4,9,13,14,15,16,17,19,21,24,25,28,29,30$, $33,37,38,40,43,44,45,49$

$1,13,14,15,16,17,28,29,30,31,33,37,38,43$, 45,49

$2,3,4,5,11,12,13,15,16,17,18,19,20,21,23$, $24,25,26,28,29,30,31,32,33,36,38,39,40,41$, $42,45,47,48,49$

$4,13,14,15,16,17,18,21,24,25,26,27,28,29$, $30,31,32,33,36,37,40,45,49$

$2,3,13,14,15,16,17,18,22,24,25,31,33,45,49$

$10,13,14,15,16,17,18,24,25,26,28,29,30,31$, $32,33,35,36,45,49$

$2,3,4,10,12,13,14,15,16,17,18,21,22,23,24$, $25,28,29,30,36,37,38,46,49$

$1,4,14,15,17,24,25,29,32,36,46,47,49$

$1,3,4,9,10,13,14,15,16,17,18,21,24,25,27$, $29,30,31,32,33,36,37,45,49$ 